\title{
Nordisk Tidsskrift for Kriminalvidenskab 1913-2013
}

\author{
Af Peter Garde ${ }^{1}$
}

\begin{abstract}
This article summarizes the first one hundred years of the Journal's history, mentions its most important authors and articles, and attempts to draw out its main characteristics. For many years the Journal has followed issues surrounding the various reforms to the Nordic penal codes and highlighted currents in criminal policy. In later years it also began to map out the (now triennial) meetings of the associations of penal law and criminal science.
\end{abstract}

\section{I. $1913-1948$}

I 1912 udsendtes et manende opråb fra 19 danske, 21 norske og 6 svenske kriminalister til at subskribere på et nyt Nordisk Tidsskrift for Strafferet. Den umiddelbare anledning var det gamle Nordisk Tidsskrift for Fangselsvaesen og praktisk Strafferets sørgelige ophør samme år, efter at den danske stat af sparsommelighedsgrunde havde inddraget sin støtte til ca. 50 mindre tidsskrifter, herunder de 1.000 kr. pr. år til NTfF. Nordiske kriminalistiske kredse tilstræbte også et tidsskrift, der ikke var koncentreret om strafudståelsen, men inddrog de nye erfaringer om forbrydelsernes opståen og straffens begrundelse og formål, kort og godt, selvom det ikke blev sagt med rene ord, programmet fra Union internationale de Droit pénal, der dominerede den kriminalistiske tænkning og reformbestræbelserne omkring forrige sekelskifte. Blandt de danske indbydere var næsten hele bestyrelsen for Dansk Kriminalistforening, og i de følgende 100 år ses et tæt samarbejde mellem foreningerne og tidsskriftet. Selvom hovedredaktionen har været dansk i hele perioden - de to første redaktører var den senere landsretspræsident Olaf Haack (1874-1948) og højesteretsassessor Eyvind Olrik (1874-1934), begge til deres død - har der til stadighed været en redaktionskomité fra alle nordiske lande. De første norske redaktører var lagmand Olaf Salomonsen og professor Jon Skeie, de svenske öfverdirektör for Fångvårdsstyrelsen Viktor Almquist og professor Nils Stjernberg.

* Title in English: Scandinavian Journal of Criminal Law and Criminology 1913-2013 
Det nye tidsskrift lagde stærkt ud i 1913 med sin første årgang - ikke 36., man kappede således forbindelsen til det i 1878 grundlagte NTfF. Som det sømmede sig, stod nordisk strafferets nestor Goos forrest med artiklen »Om Tilvæksten af Straffebud i Kommissionsudkastet til en ny almindelig borgerlig Straffelov for Danmark «, lang og knastør, man kunne kun forstå den, hvis man havde både den gamle 1866-lov og udkastet ved sin side. Den danske forenings formand Carl Torp skrev et stort tilbageblik om den internationale kriminalistiske forenings første 25 år, foranlediget også af, at København dette år var vært for foreningens kongres; NTfS bragte program og senere et kort referat. Andre danske bidrag kom fra Haack: »Om Udsagnspsykologi«, emnet var aktuelt i lyset af reformerne på straffeprocessens område, lægen Christian Geill: »Sterilisation af Forbrydere«, der fyldte debat og lovgivning helt op til 2. Verdenskrig, og fængselsmanden $G$. Brøchner-Mortensen: »Det metriske Fotografi« om et vigtigt aspekt af det Bertillonske system.

Fra Norge kom et langt referat af Salomonsen af den norske forenings årsmøde i 1912, emner strafudmåling, løsgængerloven, sikkerhedsforanstaltninger mod ikke-sindssyge forbrydere samt tilståelse og nægtelse af forbrydelser, et bidrag af Skeie om procesmåden i politisager, en artikel af Segelke Thrap om privat-publik påtale og et bidrag af Johan Scharffenberg om lægeundersøgelse under den kriminelle retspleje. Fra Sverige gav Almquist en nekrolog af den tyske kriminalist Carl Krohne, nekrologen var en yndet genre i NTfS, Stjernberg skrev om sikkerhedsforanstaltninger mod farlige tilbagefaldsforbrydere og pastor $J$. Uddin om »Fångvård och vård av frigivna«. Endelig skrev den finske strafferetsprofessor Allan Serlachius om »De andligen undermåligas straffrättsliga behandling«. Der var oplysninger om den danske straffelovsreform, om fængselsvæsenet, bl.a. om masken - fængselsdirektør Thorkil Fussing fortalte, at fangerne fik udleveret en tandbørste ved indsættelsen - og om børneforsorgen. Endelig var der vægtige anmeldelser af en undervisningsbog om efterforskning af den danske politimand Hakon Jørgensen, af Francis Hagerups udvalgte afhandlinger samt af især tysk litteratur meddelt af Hartvig Nissen. Allerede dette første år viser tidsskriftets vingefang. Der var aktuelle og principielle artikler om alle sider af kriminalistikken, efterforskning, afvigere, proces, fangebehandling, og nekrologen om Krohne gav læseren god almendannelse. I alle de nordiske lande havde man fået de ledende kriminalister til at give bidrag.

I årgang 1914 kunne læses en uhyre grundig afhandling af Salomonsen »Om vidnepligtens begrænsning i norsk straffeproces« - som eksempel på spændvidden ses drøftelsen, om det forhold, at den, der har krav på hemmeligholdelse, er afgået ved døden, medfører, at forbudet mod vidneførsel er bortfaldet, hvilket Sa- 
lomonsen bestrider under hensyn til den almene interesse $\mathrm{i}$, at man kan stole på fortroligheden (han anerkender dog en præsumption om gyldigt samtykke, hvor den pågældende direkte har begæret tiltale) - og et lige så langt flammende dansk indlæg af Viggo Koppel »Om Kønsfrihedsforbrydelser i Ægteskabet«, hvor Koppel krævede straf på linje med Torp og Viggo Bentzon i Dansk Kriminalistforening samme år. Fra Sverige kom Folke P:son Wetters forsigtige afvisning af den ubestemte straffedom af hensyn til præventionen og Hjalmar Westrings redegørelse for den nye lovgivning om spioneri, som snart blev langt mere aktuel, end lovgiver havde forestillet sig. Årets nekrolog gav Hakon Jørgensen om Bertillon, antropometriens opfinder. Referater fra fremmede tidsskrifter, især Monatsschrift für Kriminalpsychologie und Strafrechtsreform, v/ Haack, fyldte mange sider, en oplagt måde at klare sig på, når der var plads tilovers. I marts skrev Olrik en venlig recension af det store festbind til den internationale kriminalistforenings 25 års-jubilæum, men i det sidste hæfte nævntes, at tre for længst berammede internationale kongresser, begyndende med den 8 . kongres for kriminalantropologi i Budapest 14.-20. september var aflyste på grund af »den herskende sørgelige Krigstilstand «.

I 1915 fyldte Goos 80 år og blev hyldet i NTfS af Hagerup, Johan Thyrén og overstrømmende af Frantz Dahl. Haack skrev om afkortning i straffen af udstået varetægtsarrest. Friherre Lage Staël von Holstein skrev om diplomaters strafferetlige stilling. Efter Dansk Kriminalistforenings debat om fosterfordrivelse talte den norske politifuldmægtig Carl Hartmann - bedre end i dag fulgte man med i debatten i broderlandene $-\mathrm{i}$ artiklen $» \mathrm{~B} ø r$ fosterfordrivelse straffes?« for straffrihed, hvilket udløste flere danske indlæg i 1916, herunder af overretssagfører $\mathrm{Ma}$ thilde Hauschultz, som var enig med Hartmann. Oluf Krabbe, senere formand for den danske forening, gav lange referater af Zeitschrift für die gesamte Strafrechtswissenschaft, ZStW, og Haack havde læst i fransk Revue pénitentiaire et de Droit pénal, der var stærkt præget af krigen. En lov gav amnesti for tidligere desertører i fredstid, såfremt de nu meldte sig til krigstjeneste, en senator foreslog, at loven ignorerede fosterfordrivelse begået af belgiske og franske kvinder, besvangrede ved tyske soldaters voldtægt, dog kun i fire måneder efter det besatte områdes befrielse - og salg af absinth blev forbudt. Også i Danmark sås hidtil uhørte kriminaliseringer, således af den, der offentligt i skrift eller tale sigtede den danske stat for ikke at iagttage pligten til neutralitet eller søgte at ophidse befolkningen mod en krigsførende nation. Der var redegørelser for fængselsvæsen og børneforsorg, særlig en entusiastisk skildring af reformer i Sing Sing, der bl.a. medførte, at en neger i New York begik en forbrydelse for at blive sendt tilbage til Sing Sing, hvor der dog var lidt glæde ved at leve. 
I årgang 1916 fremdrog Haack den håbløst forældede dansk-vestindiske straffelovgivning, hvor alt for strenge straffe, især dødsdomme, rutinemæssigt måtte formildes ved benådning, men sluttede optimistisk med, at en reform nu var på vej. Ak og ve, inden året var omme, var øerne solgt til U.S.A., uden at reformer var indledt fra dansk side. Overlæge Chr. Keller skrev om sit asyl for åndssvage kriminelle på øen Livø, og der var en lille debat om eventuel offentlig forsorg for sinker. Historikeren Hugo Matthiessen skrev om kommunalt fængselsvæsen i tidligere århundreder. Årets nekrologer gjaldt retspsykiateren Knud Pontoppidan og østrigeren Hans Gross (Hakon Jørgensen), forfatter af den enestående indflydelsesrige Handbuch für Untersuchungsrichter. Olrik fortalte stolt om den nu gennemførte danske retsreform.

Fra Norge skrev Arne Omsted om Opstad tvangsarbejdshus, fra Sverige Jacob Linders om behandling af mindreårige forbrydere og udvidelse af de almene opdragelsesanstalters virksomhed. Haack brugte 43 tættrykte sider på referater fra ZStW, bl.a. en artikel af Dreyfus om tilbagelevering til forurettede af genstande i statens forvaring, især stjålne koster. Tysk teori er urimelig restriktiv over for forurettede, idet den relevante $\S$ fortolkes, således at hovedformålet ikke er at hjælpe forurettede til sin ret, men at fritage myndighederne for fortsat opbevaring og ansvar ved at etablere en tilstand svarende til tingsrettens forskrifter uden hensyn til de obligatoriske mellemværender. Som så ofte før var tysk teori mere dybtsøgende end vi kender til herhjemme. Men der var også referat af et massemord, 14 dræbte og 11 sårede, begået af en sindssyg tysk skolelærer.

Årgang 1917 stod i Norges tegn. Udover en påvisning af behovet for smidiggørelse af den besværlige løsgængerilov af Edvin Alten var der to lange artikler af Skeie »Nyere fremmed og norsk lovgivning til vern om forsvarshemmeligheder» - Norge var inspireret af Danmark til at kriminalisere spionage mod tredjeland på norsk område - og Otto Morgenstiernes forslag om et system af opdragelsesanstalter for så godt som alle forbrydere under 21 år i stedet for fængsel; også ungdomsfængsel, i Danmark foreslået af August Goll, blev skyet. Den idealistiske tro på forbedringens mulighed er smittende. Den svenske forestående reform sås i bidrag af Stjernberg om konkurrencespørgsmål, Almquist om »villkorlig straffdom « m.v. samt i et fyldigt referat af debatten i den svenske kriminalistforening. Et ubehageligt indtryk gjorde en ny svensk lov om »alkoholistvård« (Linders), årelang frihedsberøvelse besluttet på skriftligt grundlag ikke af domstol, men af »Konungens befallningshavande« på begæring af kommunens »nykterhetsnämnd«.

Fra Danmark fortalte Goll om den reformerede straffeproces, nyttigt for den ikke-danske læser, og Oluf J. Skjerbcek refererede en tysk undersøgelse om den 
voldsomme ungdomskriminalitet under krigen. Frantz Dahl gav en stofmættet nekrolog af hollænderen van Hamel, medgrundlægger af Union internationale de Droit pénal. Jeg kan ikke dy mig for at nævne en sag, hvor en tankvogn med petroleum dryppede på grund af utæthed, og en foretagsom mand stillede en kande under og opfangede dråberne. Den tyske rigsret dømte for tyveri, idet den faldende dråbe ikke var udgået af ejerens besiddelse. Da dråberne uden kanden blot var faldet på jorden og gået tabt, er dommen tvivlsom. I Danmark ville løsningen nok have været ulovlig tilegnelse af gods, der tilfældigt er kommet i gerningsmandens besiddelse. Nøden må have været desperat i Tyskland i 1917.

Goos døde 20. december 1917 og blev mindet af Olrik årgang 1918, »en Gigant, der taarnede Pelion oven paa Ossa og tumlede med de største Fjeldblokke, ubekymret om en enkelt Sten ikke kom til at ligge fast, indtil Bygningen stod der, storstilet og tankevækkende, præget af sin Mesters hele skabende Aand«. Bortset fra Almquists bidrag om krigstidens svenske ungdomskriminalitet - forholdene syntes ikke meget bedre end i Tyskland - og en artikel af Per Augdahl om fortolkning af straffebud om strafansvar uden skyld, bl.a. i love om lappernes rensdyrdrift, tilhørte det meste af årgangen den danske straffelovsreform, hvor Torp leverede et enmandsudkast, og en kommission af Torp, Goll, Krabbe, Olrik, en sagfører og en justitsministeriel embedsmand blev nedsat.

Torps udkast blev kommenteret i hele seks kapitler, bl.a. af Goll, der modsat Torp fandt tilsyn ved betinget dom overflødigt for andre end de yngste lovovertrædere. Krabbe gav i en artikel om forbrydelsers farlighed og opdagelsesrisikoen et af de bedste argumenter, jeg har set for forsøgets strafbarhed, at hemmelige forbrydelser som tyveri kun opklares, når gerningsmanden gribes på fersk gerning, inden han er blevet færdig. Geill skrev om brandstiftelsesmotiver med den frappante oplysning, at egentlig pyromani, sindssygdom med trang til brandstiftelse, ikke findes. Endelig holdt Torp foredrag i den svenske forening om straffe og andre retsfølger af den strafbare handling i sit udkast sammenholdt med Thyréns, en nyttig sammenfatning for både danske og svenske.

Franz von Liszt døde og mindedes i årgang 1919 af Torp og langt og lærd af Dahl - har Dahl virkelig læst alle de værker, han nævner? Begge fremhævede ham som ikke dogmatikeren, men den store popularisator og propagator. Torp fremhævede de tvivlsomme episoder i von Liszts liv, hans pangermanske fantasterier under Verdenskrigen og medunderskrift på det kontroversielle opråb »Es ist nicht wahr! « fra krigens begyndelse, men også hans fortjenester for samarbejde mellem nationerne og opfordrede til forsoning ved graven. Årets stridsemne var injuriantens ret til at føre sandhedsbevis, kun bestridt i Sverige og forhandlingsemne både i Dansk Kriminalistforening og det Nordiske Juristmøde i Stock- 
holm, efter at juristmøderne, afbrudt af Sverige efter unionsopløsningen i 1905, efter svensk initiativ var genoptaget. NTfS optrykte Krabbes indlæg fra mødet i Stockholm og en kommentar af Stjernberg, der gik imod den svenske ordning som repræsenteret af Thyrén. Krabbes overbevisende argument for den danske ordning er hensynet til den uskyldigt fornærmede, som derved făr mulighed for fuld oprejsning, idet injurianten ellers kan påberåbe sig sin manglende adgang til at føre sandhedsbevis. Haack skrev om »Krigen og Kriminaliteten «, hvor de simple tyverier var steget eksplosivt. Detailkommentarer til Torps og Thyréns udkast fyldte årgangen.

Årgang 1920 bragte Augdahls 110 pp. lange afhandling »Nødverge« (også trykt som bog, det nok eneste stadig aktuelle værk med Kristiania på titelbladet). Blandt de mange fine iagttagelser kan nævnes overvejelserne om, hvor aktuelt et forestående angreb skal være for at udløse nødværge, jeg tror ikke, at Augdahl vil anerkende anteciperet nødværge, hvor den voldsramte kvinde dræber den sovende voldsmand, og afvisningen af et krav om ædle motiver ved intervention i nødværge. Hvor - en sag fra praksis - A begav sig til sin stedfader B's hjem med en økse for at dræbe ham, fandt B i færd med at dræbe A's moder C og således reddede $\mathrm{C}$ ved at dræbe $\mathrm{B}$, anerkendte Augdahl nødværge, idet $\mathrm{A}$ ellers ville være hjemfalden til straf, hvadenten han handlede eller var passiv. Men trænger vi ikke til en stor moderne monografi om nødværge? Det andet store norske bidrag er Salomonsens foredrag i den svenske forening - disse besøg er desværre nærmest ophørt i vor tid - om erfaringerne fra den norske straffelov af 1902; en pointe: Reglerne om nedsat straf anvendes sjældent, fordi man efter opportunitetsprincippet lader de mindst skyldige slippe helt.

Af svenske Cecilia Waern en varmhjertet artikel om asylskibet Caracciolo i Napolis havn, hvor en idealistisk kvinde reddede gadedrenge for at blive banditter, bl.a. ved oplæsning af Nils Holgerssons Underbara Resa! BrøchnerMortensen skrev bl.a. om det jubilerende Vestre Fængsel og den store fangeproduktion af trælegetøj, der var så fornøjelig, at man frygtede, at fangerne ikke mere ville tilstå. Haack skrev om legemsangreb i Torps udkast og var enig i strafnedsættelse for medlidenhedsdrab (ikke gennemført). Årets nekrologer omfattede den sidste grundlægger af Union internationale, belgieren Prins. Fra Sverige bragtes fængselsstatistik i de mindste enkeltheder, ni fanger fik den hellige nadver for første gang, og fængselsbibliotekerne havde 55.007 bind.

Norges store jurist, statsmand og diplomat Francis Hagerup døde og blev mindet $i$ årgang 1921. Sverige afskaffede dødsstraf, og Almquist fortalte uhyggeligt om de sidste henrettelser; guillotinen kom kortvarigt i brug. Bortset fra en reportage af svenske Harald Salomon fra U.S.A., bl.a. om fangernes modificere- 
de selvstyre i Sing Sing, var årgangen dansk. I rækken af kommentarer til Torps udkast afviste Haack, Brøchner-Mortensen og Fussing den infamerende tugthusstraf, »den sorte Kokarde«. Muligt kunne navnet bremse forbryderen ved den yderste grænse, »Hertil og ikke længere! Næste Gang gælder det Tugthuset, og saa dybt vil du ikke synke, « men Fussing mente, at afsoningsstedet Horsens var tilstrækkeligt til at indgyde gavnlig rædsel. De praktiske ulemper oversteg langt den usikre præventive virkning. Norge og Sverige havde ikke den særlige strenge art af frihedsstraffen.

Brøchner-Mortensen aftrykte en underholdende selvbiografi af en 25-årig fange, der havde stjålet, fra han var ca. seks år gammel. »Alle mine Bekendte var saa sikker paa at nu vilde jeg blive dømt, men det blev der ikke noget af, for jeg omgaas aldrig saa Letsindigt med Tilstaaelser, og det er mig en Fryd, at maale Juridiske Kræfter med en Dommer.« Fængselspræst $C$. Ludvigsen talte for et fangeblad. Geill beskrev sædelighedsforbrydere, som ikke var sindssyge eller åndssvage, men psykisk abnorme; homoseksuelle handlinger sidestilledes med crimen bestialitatis. Retspsykiateren August Wimmer gav en kasuistik fra Kommunehospitalets Sjette Afdeling. Efter den nylige reform af den militære retspleje skrev Axel Petersen en lang artikel om emnets historik. Olrik anmeldte et festskrift til den finske veteran, friherre Wrede.

Fussing skrev i årgang 1922 en lang og kritisk omtale af en finsk fængselskommissions betænkning. I lyset af de svagheder, han påpegede om cellestraffens varighed, strafforlængelse efter et rigidt pointssystem om dårlig opførsel og en uheldig udformning af fangernes arbejdsdusør, må man håbe, at det finske justitsministerium har nærlæst hans kritik. Årgangens største bidrag var en $90 \mathrm{pp}$. lang svensk afhandling »Om förhållandet mellan ämbetsbrott och disciplinförseelser samt om de åt ämbetsmän tillämpade disciplinstraffens rättsliga natur. En studie i tysk, fransk, engelsk, dansk, norsk och finsk rätt«, der lignede den indledende tredjedel af en disputats, af Olof Barklind. Emnet var problemet, om den forsømmelige embedsmand skal dømmes til straf og muligt afsættelse efter straffeloven eller alene rammes af disciplinære sanktioner, som godt kan omfatte afskedigelse. Jeg kunne kontrollere afsnittet om dansk ret, der viste fornem beherskelse af kilder og litteratur.

Fra Norge anbefalede Conrad Falsen en udvidelse af opdragende foranstaltninger og mindre straf for unge lovovertrædere, bl.a. ved øget anvendelse af tiltalefrafald. Almquist bifaldt. Fra Danmark drøftede Geill behandlingen af sædelighedsforbrydere. Han diskuterede, men anbefalede ikke, kastration; derimod krævede han en særlig anstalt for psykisk abnorme sædelighedsforbrydere; Hersted- 
vester skimtes i horisonten. $V$. Weibull fra fængselsdirektoratet påviste fordelene ved regiesystemet og akkordbetalingen for arbejdet i de danske straffeanstalter.

I årgang 1923 skrev Hartvig Nissen om betinget påtaleundladelse, som i Norge næsten erstattede dom for de yngstes vedkommende. Svenskeren David Lund påviste, at uforholdsmæssig mange vanartede og forbryderiske børn kommer fra hjem, hvor forældrene drikker (»Det växer ingen eller dålig säd på stenig eller sumpig mark«). Goll forkastede kastration som straf og påviste, at hvert år ville højst én recidiverende sædelighedsforbryder opfylde kriteriet for kastration. Wimmer skildrede fire drabs- og voldssager, begået under "protraheret « rus. Krabbe talte for bevarelse af de korte frihedsstraffe, som er mindre skadelige end de lange straffe og ikke altid kan erstattes af bøde, og mod dagbøder, der er uklare og ikke altid omfatter hele den ulovlige vinding.

Axel Petersen skrev om den svenske militære retsplejereform, bl.a. den frapperende oplysning, at appel, »besvär«, til retten over en disciplinær straf ikke havde opsættende virkning, men højst slettelse af strafregistret, hvis straffen var uforskyldt, og ansvar for den befalingsmand, der havde ikendt straffen. I 1925 fortalte han om svenske planer om en reform af den militære straffelov og advarede imod at nøjes med et kapitel i den almindelige straffelov, da dette var upraktisk, og en borgerlig straf var mere følelig end en militær arreststraf. Af J. Hartvig Jacobsens anmeldelse af Stjernbergs straffelovskommentar fremgik, at der i visse tilfælde var ubetinget offentlig påtale for hor, og at Stjernberg ville straffe chaufføren, der kørte en herre rundt om natten for at lette hans sammentræf med løsagtige kvinder, for rufferi! Sigurd Bruun fortalte om Viborg Straffeanstalt, hvor fængselsmanden Frederik Bruuns karriere begyndte i 1845, og hvorfra en fange flygtede i 1848 for at melde sig til hæren som frivillig under den første Sønderjydske Krig. Han blev afsløret og sendt tilbage til fængslet, men fik ingen disciplinærstraf for flugten.

Efter tidligere årganges kommentarer til Torps straffelovsudkast fulgte i årgang 1924 hele ni bidrag om kommissionsforslaget af 1923, forhåbentlig læst i Justitsministeriet, hvor den nye minister Steincke nu forberedte et lovforslag. P.C. Poulsen fastslog med rette, at brandstiftelse på egen ejendom for at besvige forsikringen bør straffes som brandstiftelse og ikke som bedrageri, overlæge $S$. Thalbitzer talte imod at straffe begge parter i et homoseksuelt forhold udøvet for betaling, hvilket ville beskytte tyveri, ran, røveri og pengeafpresning (resultatet blev, at kun modtageren straffedes), og Goll fastholdt det biologiske tilregnelighedsbegreb, i kommissionen kun støttet af ham selv og Torp, idet han med åbne øjne accepterede, at dette kunne medføre behandling, ja indespærring i mange år, når en sindssyg havde begået selv en meget lille forbrydelse. 
Høiesteretsassessor Haakon Breien foreslog juryen afløst af meddomsret på grund af frifindelser af oplagt skyldige og skrøbelighederne ved, at rettens læge og juridiske elementer virkede hver for sig. Fridtjov Hegge, lagmand i Gula- og Frostating og stortingsmand for Venstre, kaldte Breien et redskab for reaktionære kræfter i Kristiania, der med urette troede, at deres egne stemninger gav udtryk for det hele lands. Hegge afviste dog ikke adgang for retten til at tilsidesætte oplagt fejlagtige nævningefrifindelser, indført i Norge i 1933 med god virkning. Breien replicerede, at reaktionære politikere var under hypnose af det gamle jurybegreb og intet havde lært og intet glemt. Almquist resumerede lovgivningens status i Sverige. Wimmer redegjorde for sovesygens forensiske psykiatri. Chefen for Københavns Opdagelsespoliti S. Tage-Jensen, der før havde fortalt om tilkaldelse af brandkyndige i brandsager og undersøgelser på gerningssteder, fortalte om forfalskede dokumenter, om det så var blyantskrift, kunne forfalskning afsløres. Desværre havde han efter sin afsked i 1925 ikke psykisk overskud til disse indblik i den praktiske efterforskning.

I årgang 1925 ændrede de norske redaktører adressen fra Kristiania til Oslo, og redaktionen udvidedes med to finske redaktører, Serlachius og professor $O$. Hj. Granfelt. I »Rättvisan i Finland« forsvarede Serlachius retsvæsenet imod angreb fra den svenske advokat Georg Branting, forsvarer i en forræderisag mod ledende kommunister, senere socialdemokratisk riksdagsmedlem; Serlachius påpegede, at meget, der var ufarligt i Sverige, var samfundsfarligt i Finland. Den svenske psykiater Alfred Petrén vendte sig imod gældende praksis om nedsat straf til de »halvabnorme « formindsket tilregnelige forbrydere og ønskede forvaring, endog indgreb mod de åbenbart samfundsfarlige psykisk abnorme, inden de havde begået en forbrydelse. Sorenskriver P.N. Arentz, norsk, foreslog omstødelse af nævningefrifindelser, der ikke var båret af et flertal i nævningetinget, og påpegede, at tiltaltes ret til at udskyde 5 af 17 nævninger næsten gav ham ret til at udpege sine egne dommere.

Resten af årgangen var stort set dansk. Haack afviste straf for voldtægt $\mathrm{i}$ ægteskabet og veg tilbage fra at give hustruen ret til yderste nødværge, drab af gerningsmanden; Henrik Sachs afviste særlig mild straf for $»$ Rapseri«, der ramte de mindre velstillede; Troels G. Jørgensen påviste, at den utilfredsstillende form for optagelse af politirapporter medfører, at falsk forklaring til politiet ikke kan straffes; K. Borgsmidt-Hansen vendte sig imod navnet »Ungdomsfaengsel « og advarede imod muligheden for at »forbryde sig fri«, ved kort almindelig straf undgå lang ubestemt tilbageholdelse. Benny Levin gennemgik æresoprejsning, »Rehabilitation «, bl.a. at da en udenlandsk dom ikke er vanærende i Danmark, vil æresoprejsning allerede derfor blive nægtet. L.Th. Arnskov fortalte om "probation« i 
U.S.A. på grundlag af sine erfaringer som vicekonsul i New York, hvor en brav dommer lod tre ubetænksomme danske småtyve slippe med denne sanktion, og Haack fortalte fra $»$ Schweizerische Zeitschrift für Strafrecht $«$, at fostre fik fingeraftryk i fjerde svangerskabsmåned, og at daktyloskopi var kendt i Kina fra $650 \mathrm{e}$. Kr., ja muligt endog i Ninive ca. år 2.000 f. Kr.

Skeie gennemgik i årgang 1926 over 111 pp. ændringsforslagene til den norske straffelov, især om ansvar for handlinger i beruselse - den tidligere straffrihed blev nu fornuftigvis ophævet - og sikringsmidler over for de farlige. Omstridt var forslaget om sikring i form af 5 års obligatorisk frihedsberøvelse for den seks gange straffede, selv hvis hver dom kun omfattede ét lille tyveri, "plagsomme snyltere«. Hartvig Nissen påviste i sin kritik, at hvis disse regler var gældende 1920-1925, havde sikring været anvendt 14 gange for sædelighedsforbrydere, 3 gange for voldsmænd, men 346 gange for tyve m.v., heraf 311 på grund af 6 tidligere straffe. Riksadvokat Kjerschow skrev om forbrydelsernes årsager, bl.a. den kuriøse oplysning, at falsk anklage er en specifik kvindelig forbrydelse, og en uhyggelig historie om et barnemord med partering af liget; var faderen og/eller moderen - der tilstod tre gange og hver gang trak tilståelsen tilbage - skyldig? Dommen, livsvarigt strafarbejde til manden og frifindelse af kvinden, var nok rigtig, men syv år efter dræbte hun sit næste barn! Överdirektör A.P. Arvelo beskrev det progressive finske system, og G. Modeen skrev om Finland under alkoholforbudet (som varede 1919-1932), der viste en beskeden nedgang i andre forbrydelser, som dog i høj grad blev begåede af berusede, og mange overtrædelser af selve forbudsloven.

Wimmer skildrede den kroniske morfinisme, som modsat nu ikke spillede nogen større rolle. Psykiateren Georg Neve afviste et rent medicinsk kriterium for sindssyges straffrihed, bl.a. fordi visse sindssygdomme optræder i en sådan fortynding, at det ville være meningsløst at lade dem medføre straffrihed. Almquist ønskede frie hænder for dommeren i sanktionsfastsættelsen, »Goda domare äro bättre än den bästa lag«, men også efteruddannelse i psykiatri, penologi, retsmedicin m.v. Anmeldelserne omfattede Salomonsens straffeproceslovskommentar, Andreas Bjerre: Bidrag till mordets psykologi. Kriminalpsykologiska studier, den bog burde genudgives - i næste nr. fulgte sørgeligt forfatterens nekrolog - og den rumænske ildsjæl Vespasien Pella: La Criminalité Collective des États et le Droit Pénal de l'Avenir, et detailleret projekt om strafansvar både for stater og statsledere, den første spire til en international straffedomstol; »la guerre d'agression est un crime « og skal straffes som sådan.

En dengang levende genre, som desværre senere er udgået, var orientering om lovgivning i ikke-nordiske lande, i årgang 1927 Levin om Sovjetrusland, hvis 
straffelov omfattede handlinger begåede i udlandet af udlændinge mod den russiske statsforfatnings grundsætninger og anvendte dødsstraf for 42 forbrydelser, dog ikke drab, hvor højeste straf var 10 års fængsel; Torp om Czechoslovakiet, hvis nylige straffelovsforslag skelnede mellem forbrydelser og forseelser ikke efter objektiv grovhed, men gerningsmandens subjektive holdning, hvor »niedrige Gesinnung« medførte klassifikation som forbrydelse; vigtigst, Hartvig Jacobsen om forbrydelsens retsfølger efter det italienske forslag af 1921 af Ferri, hvor gerningsmandens farlighed, ikke hans skyld, var det afgørende kriterium - også den sindssyge kunne straffes - men sanktionerne var yderlig strenge, især over for mindreårige, med tilbageholdelse op til 10 år som minimum!

Westring og Hakon Jørgensen, berømt for sit system om fjernidentificering, mindedes. Ragnar Bergendal drog grænsen mellem det blotte recidiv og vane- og erhvervsmæssige forbrydere. Almquist talte for nedfældelse af retsforklaringer i retsbogen og oplyste om nye regler om internering af de værste recidivister, hvor en femmands»nämnd« skulle godkende interneringen. E. Schäffer oversatte en tysk artikel, hvis forfatter, der placerer sig selv i mellemklassen af forbrydere, hylder den store forbryder som et overmenneske. Den nye danske fængselsdirektør Erik Kampmann fortalte, at ministeriet havde forbudt spiritistisk gudstjeneste i straffeanstalterne.

Det længste bidrag i årgang 1928 var Geills beskrivelse af de efter en nylig lov internerede, især sædelighedsforbrydere. Han anerkendte en medfødt, for al psykisk behandling upåvirkelig homoseksualitet, men tilføjede, at selv de mest ivrige biologer vanskeligt kunne hævde, at et sådant individ var helt psykisk normal. Han efterlyste en særlig institution for de internerede. Årgangens bedste bidrag var Kjerschows overbevisende anbefaling af opportunitetsprincippet og redegørelse for norsk påtalepraksis; hvis man genoptrykker gamle artikler fra NTfS, står denne godt fremme i køen. Hj. Nyman beskrev den barske svenske løsdriverlovgivning med administrativ beslutning om tvangsarbejde op til 3 år samt et nyt forslag om judiciel prøvning og afskaffelse af ordet »lösdrivare«. Petrén glædede sig over indførelse af sindssygeafdelinger i svenske fængsler, senest Långholmen; før blev fangerne indlagt på borgerlige hospitaler uden indregning af opholdet i afsoningstiden. Lagmand Rolfsen støttede omdannelse af juryen til meddomsret og fremdrog uheldige eksempler på udtagelse af jurymænd, f.eks. en by, der kun indstillede »forbudsmenn«.

V. Verkko viste dødsstraffens manglende virkning; i Finland var dødsstraf endnu et praktisk problem. Arnold Sölvén drøftede custodia honesta ud fra et svensk forslag; som jeg læser det, kan det kun overvejes seriøst ved ikkevoldelige politiske forbrydelser (var den milde behandling af Hitler efter Mün- 
chen 1923 en malplaceret brug af custodia honesta?). Almquist afgik og blev hyldet. V. From fortalte om Christianshavns Straffeanstalt ved dens nedlæggelse. Wimmer drøftede den helbredte paralytikers medicolegale status. Krabbe anmeldte en bog af Troels G. Jørgensen om Ørsted som dommer; Ørsted indstillede en kvinde, der var dømt til døden efter Norske Lov 6-13-22 for rømning fra sin mand med en anden gift mand, benådet på vilkår af 14 dages vand og brød.

Carl Torp og Enrico Ferri døde og mindedes i årgang 1929. Petrén drøftede det besværlige problem, når samme person både skal interneres i alkoholistanstalt og afsone straf, f.eks. ubetalte fylleribøder. Kan det ene træde i stedet for det andet? Otto Grönlund skildrede stigningen i förskingring og trolöshet (underslæb, mandatsvig) i Sverige i alle befolkningslag, også i offentlig tjeneste, især postvæsenet og sognefogeder, fjärdingsmän, hvilket havde medført indførelse af ubetinget offentlig påtale for disse overtrædelser, og Almquist anbefalede hyppig og, når en mand havde flere kasser, samtidig revision, og at man ophørte med at beundre den morsomme selskabsbroder, som »lever flott«, og med at bebyrde den samme mindre kvalificerede mand med alt for mange tillidshverv. Iv. Rummelhoff talte varmt om det norske forsorgsarbejde for lovovertrædere - gik det an at lade samme forening hjælpe de endnu ustraffede unge og de gamle kriminelle? og deres familier. Axel Hertel fortalte om reformarbejdet i de belgiske fængsler, siden Belgien i 1775 »opfandt« det Auburnske princip 40 år før Auburn, bl.a. de store undersøgelser af fangerne ved indsættelsen. Conrad Falsen talte for prøveløsladelse af tvangsarbejderne, såsnart de havde optjent et i forvejen fastsat beløb $i$ arbejdspenge, uden yderligere vilkår. Svensk er ikke samme sprog øst og vest for Bottenhavet, i Finland hed en fangevogter i 1929 en »fångknekt«.

Den store begivenhed i årgang 1930 var vedtagelsen af den danske straffelov, markeret ved en 48 pp. lang artikel af generalauditør Victor Pürschel, der som folketingsudvalgets konservative formand havde god andel i sagens lykkelige løsning. Blandt andre enkeltheder anerkendte han, at selv det højeste retsgode, menneskeliv, kunne ofres som led i nødret, således en båd med 2 eller 3 mand for at redde et skib fuldt af passagerer. Wimmer fortalte om de patologiske svindlere, især den mytomane psykopat som Ibsens Peer Gynt; mange af disse kom i konflikt med loven, en patient var straffet 76 gange, en anden havde fået tid til 500 ensartede bedragerier; de straffes som normale, og ved stadigt recidiv må de forvares for længere tid. Verkko: »Kriminalstatistiken och den verkliga brottsligheten « så en vis overensstemmelse ved forbrydelser rettet mod livet, endog samspil med kriminalpsykologien; i 1915 oplevede Finland nedgang i vold med døden til følge, idet potentielle forbrydere af angst for krigslovene lod kniven blive hjemme, men ikke for overlagt drab, hvor gerningsmanden ikke forventer afsløring. 
Ved andre forbrydelser var der intet sammenfald, i Frankrig rejstes i 1912 tiltale i 89 sager om fosterdrab, men mørketallet var ca. 200.000!

Sverige fik et forslag til steriliseringslov, men ikke kastration (Petrén). Almquist skrev om fængslets udvikling, Hartvig Nissen om 100 års successive reformer af norsk fængselsvæsen, bl.a. indførelsen af arbejdsskolen i 1928, og Kristian Hansson om den norske lov af 1929 om sikring, mindre skematisk end det kritiserede forslag af 1925. Kampmann gennemgik den preussiske fængselsreform af 1929, et konsekvent progressivt system efter nøje undersøgelse af fangen ved indsættelsen; i musiklandet Tyskland var deltagelse i fangekor og fængselsorkester led i progressionen, men også søndagsspadsereture med en fangevogter i civilt tøj, endog op til 2 ugers orlov pr. år. Kampmanns slutning, at dansk fængselsvæsen kan lære af Preussen, viser, hvor meget værdifuldt der gik tabt i 1933. Årets nekrolog: Julius Grotenfelt fra Finlands Högsta Domstolen.

I årgang 1931 blev Fussings indsats for dansk fængselsvæsen mindet af Kampmann efter hans alt for tidlige død. Goll, vicepræsident (en af 53) og rapporteur général på emnet en fælles international kodifikation, fortalte om konferencen i Prag i 1930 i Commission internationale pénale et pénitentiaire. Conrad Falsen fastholdt i sit bidrag til Prag »Fengselsmannens utdannelse« juridisk eksamen med tillæg af lidt psykiatri for fængselsdirektøren, så gerne, at præsten var tidligere ungdoms- eller sømandspræst, og anbefalede en pensionsalder på 60 år for at modvirke skeptisk magelighed. Sterilisationsspørgsmålet i de nordiske lande blev omtalt af Haack; kun Danmark havde vedtaget en lov, men de andre lande var ved at komme med. Petrén skrev om svensk sindssygelovgivning. Goll gav over 58 pp. en studie over massemorderen Peter Kürten, vampyren fra Düsseldorf, hvis proces han havde overværet. Skildringen af det uhyggelige indtryk af Kürtens fremtræden i retten gør indtryk. Da Kürten ikke var utilregnelig, var dødsdommen korrekt, men Goll tilføjer, at han efter den nye danske straffelov kunne idømmes psykopatforvaring.

Aage Lotinga skrev om den fascistiske italienske straffelov, ikke positivistisk som forslaget af 1921, men klassisk-indeterministisk. Dødsstraffen var genindført. Efter Verdenskrigens erfaringer blev défaitisme og svækkelse af kurserse i krigstid kriminaliseret. Trods modvilje mod enkeltheder anerkendte han lovværkets romersk-monumentale ånd. Stephan Hurwitz anmeldte Krabbes straffelovskommentar og et tysk festskrift på 1.200 pp. med 39 forfattere, Tyskland var endnu det store juristland. Af de 39 blev James Goldschmidt forjaget som jøde og døde i landflygtighed og Gustav Radbruch afskediget, indtil han efter 1945 genskabte tysk jura nærmest som naturret, men det kunne de glade mænd ikke forudse i 1930; Edmund Mezger møder vi igen i 1934. 
Straffeprocesreformer fyldte en stor del af årgang 1932. Per Santesson skrev om svenske reformer i akkusatorisk retning; vigtige spørgsmål var opretholdelse af de kommunale rådstueretter i byerne og lægdommernes, nämndens, organisation og stemmevægt. Granfelt skrev mistrøstigt om den langtrukne reform i Finland, som var gået i stå, på landet var der ingen juridisk uddannede anklagere og ingen forsvarere, men retten beskyttede tiltaltes interesser ex officio. Victor Hansen skrev om den friske danske reform (uden domsmænd). Lotinga skrev om den nylige italienske reform; nævningerne var afskaffede som »baseret paa den misforstaaede Idé om Folkets Suverænitet med Tilsidesættelse af Statsorganismens Krav«, og i stedet var indført elitedomsmænd; kvinder var udelukkede på grund af deres »subjektive Indstilling og Mangel paa Logik.«

Kampmann skrev om ungdomsfængslet, hvis klientel var de »begyndende Professions- og Vaneforbrydere «, om særanstalten for de moralsk defekte psykopater, som han sammenlignede med Lombrosos »fødte Forbrydere«, og - efter en pessimistisk artikel af dommer Poul Skadhauge - om rationalisme i straffuldbyrdelsen med et lysere sind. Goll beskrev seks grupper afvigere, der var udskilt til individualiserende behandling i den nye straffelov. Fængselsinspektør Waagensen skrev om privates medvirkning ved fuldbyrdelsen og anbefalede, at den udpegede tilsynsførende efter prøveløsladelsen knytter forbindelse med fangen i betimelig tid inden løsladelsen. Anker Riis skrev om ubevidste motiver og citerede Freudianere, der kaldte dommerens gerning en konstant flugt fra personligt ansvar! Endelig skrev E. Haskin om den preussiske reform, om årlig orlov til afhjælpning af »Seksualnød«, om kamp mod korte straffe ved betinget udsættelse af afsoning og kulminationen, da en imponeret landdagsmand sagde »De, Hr. Minister, kan kaldes en Forkæmper for Fangernes Menneskeværd, « og slutter selv: »Idet Ministeren udsendte Forordningen af 7. juni, blev han det.«

I årgang 1933 beskrev Kampmann den nye danske straffelov i en artikel om dødsstraffens afskaffelse, dog mod et stort mindretal i Rigsdagen, og om fængselsvæsenet, om gradvis lempelse af cellestraffen, det progressive system og de individualiserende særforanstaltninger; Waagensen skildrede arresthusene; rygning, som i dag forbydes stadig mere, var tilladt for varetægts- og hæftefanger, men for fængselsfanger var røgtobak forbudt og kun skråtobak tilladt, som fangen måtte købe selv. Polen fik i 1932 endelig en straffelov til afløsning af delingsmagternes love (Gregor Wirschubski). Lotinga tog sovjetisk strafferetspleje alvorligt. Forsvareren havde pligt til at bidrage til sagens opklaring. Hvad Lotinga ikke kunne forudse, var, at den fremtrædende jurist Krylenko, den eneste han nævner ved navn, få år efter blev likvideret som folkefjende. 
Ekspedisjonschef, chef for Fengselsstyret i Oslo Kyhn Gløersen kritiserede den overvættes brug af sikring efter de nye regler, især gentagelsesreglen, når den tidligere dom var gammel og man ikke havde forsøgt med en lang bestemt straf. Omvendt ønskede dommer Nikolaj Hoff ubestemte domme i næsten alle sager. Finland havde nu fået sin lov om farlige recidivister (Arvelo). Kjerschow: »Lægens strafferetslige ansvar for kirurgiske operasjoner « omtalte det vanskelige samtykkeproblem, således når en næsten myndig og værgen var uenige. To andre norske bidrag om andet end dagens problemer omtalte henrettelse in effigie, kendt fra Højesterets domme i 1661 og 1663 om Kai Lykke og Corfitz Ulfeldt (Fredrik Grøn) og »Kringkastningsselskapenes strafferettslige Ansvar« af Arnold Rcestad, der ikke troede på retlig indskriden mod f.eks. ophidselse til krig, had eller foragt mod en andet lands regering, under Verdenskrigen indført i Danmark, men afvist i Norge. Bergendal mindedes den nylig afdøde Johan Thyrén, formens elegance hos grand-seigneuren og hans største bedrift, det monumentale og næsten færdige straffelovsudkast.

I årgang 1934 blev Skeie afløst af Kyhn Gløersen som norsk redaktør. Politiadvokat Harald Prytz skrev om kvinden, der blev straffet stadig strengere for hundreder af små tyverier i butikker, indtil Prytz som anklager indhentede en psykoanalytisk erklæring om, at tyverierne var stedfortrædere for coïtus, hvorefter hun via Retslægerådet fik tiltalefrafald og blev reddet til et normalt liv. Derimod var Wimmer skeptisk over for psykoanalyse i strafferetsplejen; han drøftede også bestemmelsen af åndssvaghedens grader, hvad er »i højere Grad«? BinetSimon prøverne måtte suppleres med et klinisk-psykologisk skøn; han accepterede arbejdshus for lettere åndssvage. Et foredrag i Trondhjem af Kristian Hansson afspejlede tidens idealer; samfundets beskyttelse måtte forenes med straffens formålstjenlighed, forskellige forbrydere krævede forskellig behandling, men retfærdighedsidealet udelukkede helt ubestemte domme. Anklagemyndigheden i Finland var nu forbedret ved oprettelse af tre embeder som statsåklagare ved hovrätterne (Granfelt), og Schlyter satte reformen i gang i Sverige. Krabbe skrev årets nekrolog om Carl Ussing, idealistisk praktiker par excellence, hvis foredrag om frihedsberøvelse han kaldte det bedste i Kriminalistforeningen.

Men vigtigst var efterretningerne om den kriminalistiske regression i Tyskland efter, hvad man eufemistisk kaldte »den store Omvæltning « (Waagensen og Haack). Reformen af 1929 blev ophævet, straffens opgave var at »vække Forbryderens Skyldbevidsthed og bibringe ham den Overbevisning, at Straffetiden er en Bodstid«. Fangernes livsophold skulle være under de uforskyldt arbejdsløses. Førerprincippet blev genindført med absolut magt til anstaltslederen. Sterilisation gennemførtes mod den berørtes vilje, kastration indførtes som straf for sædelig- 
hedsforbrydelser, og farlige vaneforbrydere, personer med to tidligere straffe på mindst 6 måneder, kunne ved en ny $»$ Vergehen« idømmes tugthus indtil 5 år, ved »Verbrechung« 15 år. Hurwitz nærlæste et værk af Edmund Mezger, der kombinerede klassisk kriminologi med nazistisk kriminalpolitik på en måde, som forekom Hurwitz uklar, og som jeg efter at have læst anmeldelsen to gange heller ikke forstår. Mezger definerede i 1935 en retsstridig handling som en handling imod den nationalsocialistiske verdensanskuelse; i 1944 beskrev han jødernes høje kriminalitet og krævede udryddelse af kriminelle stammer. Han blev emeritus i 1952 og fik et festskrift, mon hele bibliografien var med?

Olrik døde og fik en fyldig nekrolog i årgang 1935 af Frantz Dahl. Kampmann blev ny dansk medredaktør. Også Hans Munch-Petersen, retsreformens og nævningernes forkæmper, døde. Årgangen var fyldt med sterilisation, især en fyldig dansk betænkning om de gode resultater af loven af 1929 samt en ny dansk lov og et finsk lovforslag (Honkasalo). Tvungen kastration af sædelighedsforbrydere blev vedtaget (men aldrig ført ud i praksis) i Danmark og overvejet i Finland, hvis alternativet var livsvarig internering. Nyman beskrev ungdomsfængsel, svangerskabsafbrydelse og fangebehandling bl.a. med den iagttagelse, også kendt i Danmark, at de bedst tilpassede fanger ofte klarer sig dårligst efter løsladelse. Finland viste kolossale fangetal, 9.205 fanger, deraf 5.826 i tugthus, mod f.eks. 2.208 i Danmark. Nissen skrev om fremskridt, men også om Akershus Landsfengsel, der allerede krævedes lukket i 1841 (det skete først i 1950); et udslag af det progressive system i Norge var gardiner i cellerne i sidste klasse. Vridsløselilles kirkesal blev reduceret til én etage efter indretning af normale kirkestole.

Karl A. Andresen omtalte en norsk sag om anonyme smædebreve, og George Schrøder to danske sager om ekshibitionisme; at række tunge var beslægtet med at demonstrere genitalia! Finland fik en lov om behandling af småsager (Arvelo). Den nazistisk inficerede fængselskongres i Berlin blev ikke refereret, men tre danske (Kampmann, Weibull og Wandall) og én norsk (Falsen) rapport blev aftrykt; fangernes livsophold blev modsat det nye Tyskland defineret som den jævne arbejdsmand, idet et lavere niveau ville nedbryde; de danske optagelseshjem til løsladte fanger var ikke beregnede på bymennesker. Den lærde Dahl anmeldte en biografi om Feuerbach og Hurwitz to uhyggelige nye tyske værker; kvintessensen af Karl Siegerts jura var: »Was dem Volke im höheren Sinne dient, ist recht, was ihm schadet, ist unrecht, « og H. von Weber ville modsat Pella ikke kriminalisere angrebskrig, når denne var »der Ausfluss einer tiefen Lebensnot des Volkes, « som ikke fik nødvendigt »Raum«. En finsk kriminalistforening grundlagdes med Serlachius som formand, men desværre kunne årbogen ikke læses uden kendskab til finsk. 
Serlachius døde og mindedes af Tulenheimo i årgang 1936 som Särkilahti; bl.a. havde han grundlagt det første finsksprogede juridiske tidsskrift Lakimies. Arvelo blev ny redaktør. Højesteretsdommer Einar Arnorsson skrev det første islandske bidrag om svangerskabsloven af 1935, to år før den danske. Man antog 200 aborter pr. år, men havde aldrig haft en straffesag; loven indførte en snæver medicinsk indikation; en læge, der bistod en rask kvinde med prævention, blev straffet efter lægeloven. Adam Jacobi skrev om strafferettens nyeste udvikling i Tyskland. Trods frastødende enkeltheder som straffelove med tilbagevirkende kraft og vidtgående analogi, hvorefter udtrykkelig lovhjemmel ikke var krævet, hvis gerningen stred imod straffelovens grundtanke eller folkets sunde retsbevidsthed, var dommerne ikke gået over gevind; nogle mente, at anbringelse $\mathrm{i}$ koncentrationslejr var underkastet domstolsprøvelse! Verkko beskrev international kriminalstatistik, fyldt med franske, ja italienske citater; på grund af juryens ofte irrationelle frifindelser var udgangspunktet ved bedømmelse af forbrydelser mod liv og legeme i lande med jury ikke doms-, men tiltalestatistik. Aage Worm skrev om straf i Holland, hvor individualiseringen gik så vidt, at der var særlige afdelinger for fanger over 60. Der var ingen kriminel lavalder, hvorfor børn afsonede småbøder for manglende cykellygte; hver retskreds havde en afdeling for »Kinderrecht «, som ofte dømte til »Zuchtshool«; der var tre forskellige psykopatanstalter, to privatdrevne.

Nyman havde hele tre bidrag, bl.a. om bødeinddrivelse; da 9.369 afsonede bøder i 1934, var reformer nødvendige. Hanne-Marie Tjensvoll skrev om Institut de Criminologie i Paris. Gunnar Rudstedt skrev om høje svenske høje recidivtal for ungdomsfængsel. Oluf Skjerboek omtalte en svensk betænkning om opdragelseshjem for vanskelige børn samt børneforsorg og kriminalitet i Danmark og anbefalede hurtigst mulige fjernelse af børnene fra hjemmet. Almquist talte mod hævn og gengældelse og for humanitet, og Nissen optrykte sit bidrag til Berlin 1935 om den humaniserende fangebehandlings gode virkninger. Jørgensen talte om den nyeste højesteretspraksis og afslørede, at Højesteret oftere skærpede end mildnede. Henrik Sachs omtalte en international kriminalistkonference i København med Goll som præsident, bl.a. om bekæmpelse af terrorisme. Haack anmeldte Birger Wedberg: Tärningkast om liv og død. Jeg har læst bogen og gentager Haacks ros, den er aldeles fortræffelig.

Goll afgik og blev hyldet forrest $\mathrm{i}$ årgang 1937, men døde straks efter og blev mindet i næste nummer som den store praktiker og humanist med den strålende personlighed. Blandt de gamle bekendte skrev Victor Hansen om den danske straffeprocesreform, hvor domsmændene, som han gerne så som generel erstatning for juryen, nu var indført. Tjensvoll skrev om de dårlige franske fængsler; 
det værste, St. Lazare, lå i en bygning fra det 11. århundrede, restaureret 1680 og først nedlagt 1927! Verkko resumerede sin bindstærke finsksprogede undersøgelse og redegjorde for kønnet som den vigtigste biologiske faktor for volds- og drabsforbrydelser. Kvinder begik oftere overlagt mord end voldsomt »viljadråp«, var anstiftere og meddelagtige, ikke gerningsmænd, brugte gift, men ikke stikvåben, og skamferede utro elskere ved at kaste vitriol i deres ansigt. Nissen beskrev med et fint billede arv og milieu som tandhjul, der griber ind i hinanden. Falsen fortalte en solstrålehistorie om tvangsarbejdere, der havde bygget en 6.584 meter lang nyttig vejstrækning i Rogaland. Nyman skrev om de restriktive optagelsesregler for forvaringsanstalterne, om frivillig sterilisering og om den vanvittige "preventivlag" af 1910 med forbud mod falbydning af svangerskabsforebyggende midler. Worm skrev om behandlingen af abnorme forbrydere og internerede vaneforbrydere i Belgien; virkningen var så god, at indsatte, der havde fået en »congé« for at søge arbejde, frivilligt vendte tilbage til anstalten, hvis bestræbelsen ikke lykkedes. Arvelo skrev om nye finske love om forsorg for børn - som bl.a. ikke måtte arbejde som »kringvandrande« sanger, musikant, danser eller akrobat, normalt ej heller i restauranter - alkoholister og løsdrivere.

Nye forfattere var Svend Riemer om den sociologiske baggrund for incest i Sverige, hvor forbrydelsen var koncentreret i landdistrikternes underklasse, »statarna«, hvor ligegyldighed og håbløshed dominerede; en dømt fader sagde, at det var bedst selv at være fader til datterens uægte børn, da han alligevel skulle forsørge dem. Erik Westerkjar skrev om den nye danske svangerskabslovgivning. A.P. Larsen beskrev den nye danske militære straffelov og retsplejelov og fremhævede den generelle regel om straf for pligtstridigt forhold, der var nødvendig af hensynet til disciplinen. Nils Regner beskrev nye svenske regler om bødeinddrivelse, nu tog man fat på bødeafsoningsproblemet. Ragnar Lindström drøftede, om fanger kunne påklage disciplinærstraffe til den øverste forvaltningsmyndighed, regeringsrätten.

I årgang 1938 lykønskede Bergendal NTfS med de første 25 år, efterlyste mere penologi og fremhævede Almquists ophøjede menneskelighed. Konklusionen af Hugo Christensens 84 pp. lange afhandling »Nogle Betragtninger over Straffens Begrundelse og Formaal«, var, at balancens genoprettelse er kvintessensen af formålet, og at den offentlige mening må kunne tiltræde straffen; der er mange gode citater fra Ørsted, således som begrundelse for en mild straf: »En ikke ubetydelig Del af Straffelovens Kraft beror paa den Skændsel, der følger med at erkendes og straffes som Forbryder ... Jo mere man efter et Folks Tænkemaade kan regne paa hine Forestillingers Virksomhed, jo mindre behøver Straffen at indeholde af egentlig fysisk Onde.« 
Tjensvoll påviste norsk rets strenghed med hensyn til rettighedsfortabelse efter straffedom, endog retten til »alderstrygd« gik tabt. Thomas Sinding analyserede norsk straffelovs regler om lykkespil og differencehandel, til tider forbudt som hasard. Nissen afvejede strafafsoning efterfulgt af sikring over for ren sikkerhedsforvaring. Der var oplysning om reformer og reformplaner, således betinget dom uden straffastsættelse i Sverige (Nyman); islandske og finske love om sterilisation og kastration (Tryggvi Sveinbjörnsson og Honkasalo), hvor adgangen til indgreb ved tvang var meget vidtgående, men restriktiv over for frivillige indgreb, samt danske love om enhedspoliti og de kommunale arresthuses overgang til staten (E. Thune Jacobsen, Kampmann). Falsen holdt et stemningsmættet foredrag om Opstad tvangsarbeidshus, Hurwitz mindedes Frantz Dahl, og Westerkjær anmeldte den første fornemme De nordiska Kriminalistföreningarnas Ärsbok 1936.

Salomonsen døde og blev mindet $i$ årgang 1939. Ny norsk redaktør blev riksadvokat Haakon Sund. Over for Hugo Christensens naturvidenskabelige teori om kræfternes balance fremhævede Karl O. Christiansen straffens etiske grundvold. Knud Sand, Retslægeraadets formand, skildrede på 105 pp. de heldige følger af 187 frivillige kastrationer i Danmark gennem 10 år; der var næsten ikke tilbagefald i kriminalitet, mange var prøveudskrevet, og hjemlen til kastration ved tvang var aldrig blevet udnyttet. Trygve Leivestad hævdede, at determinismen kun var mulig som et abstrakt tilskuersynspunkt, og at den enkelte aldrig kunne betragte sig selv som behersket af ubrydelige love. L.G. Lindencrona hævdede i »Ungdomsbrottsligheten «, at moderens fravær fra hjemmet ved erhvervsarbejde kunne skade barnets sociale tilpasning og udvikling. Nyman og Ernst Leche oplyste om prøveløsladelse og straffeprocessuelle reformforslag i Sverige. Schweiz fik med snævert flertal i folkeafstemning en enhedsstraffelov, hvor strafferetten før hørte under de 25 kantoner, af hvilke to endog ikke havde straffelove, men dømte efter uskreven sædvaneret (Krabbe), og Allan Etzler besøgte fængslerne i Estland og Letland, dårligere end de svenske, men i klar fremgang, ak ja, kun tre år efter sænkede mørket sig. Med forbillede i det tyske universitet i Prag og Køln skitserede Heinz-Werner Walensky unge juristers undervisning i kriminalistiske hjælpevidenskaber.

Haacks to lange retshistoriske artikler om trolddom, heksebrændinger og forskrivninger til djævelen i det 17.-18. århundrede fyldte årgang 1940. Rudstedt beskrev et interessant eksperiment på ungdomsfængslerne om frigang til at tage arbejde hos en arbejdsgiver i den sidste tid inden løsladelsen til forberedelse af denne. Pastor Garpestad fortalte om norske fangers pauvre skolekundskaber, Nissen om psykiaternes store rolle i strafferetsplejen og fangebehandlingen under den nye individualiserende behandling. Walter Lunden fortalte på svensk om 
ungdomskriminalitet i U.S.A. og Miltiades Porfyrogenis på dansk om det stadige arbejde med en ny græsk straffelov, i gang siden 1904 uanset mellemliggende revolutioner og regimeforandringer. Sverige fik en kriminalteknisk anstalt $(E$. Glas), reformarbejdet med den svenske løsdriverlov kom endnu et lille nyk videre (Ivar Agge), og kronohäkten overgik fra länsstyrelserne til fångvårdsstyrelsen. »Paa Grund af den internationale Situation« blev den nøje planlagte kongres i Rom i Commission internationale pénale et pénitentiaire udsat, foreløbig til Aaret 1942«. 1914 om igen.

Årgang 1941 stod i de store værkers tegn. J. Scharling skrev en anerkendende anmeldelse af Hurwitz: Den danske Strafferetspleje, og P.M. Sachs skrev om værker af Skeie, Agge og Krabbe, hvor generalpræventionen spillede en større rolle end i NTfS's spalter. Da Danmark kun havde ét ungdomsfængsel, advarede Cai Jensen mod at anbringe bander og komplotter i dette. Hardy Göransson skrev om udviklingen i Sverige fra »den oskuldsfulla barnaåldern inmängd ibland mannaålders avskum « i 1825 til det nye ungdomsfængsel, skabt især ved påvirkning fra Danmark, og Sverker Groth skrev om radikale indgreb mod den voksende svenske ungdomskriminalitet.

Anmeldelsen af Kjcersgaard: Forbrydelsens Aarsager nævnte, at da nazisterne jog kvinderne tilbage til hjemmet, faldt den kvindelige kriminalitet drastisk. Fridtjof Lassen påviste, at det filosofiske årsagsbegreb ikke er lig den juridiske årsag. Kristian Hansson grundede over, at kriminaliteten er konstant, uanset hvilken teori der styrer dens bekæmpelse; justisdepartementet afgjorde sager om benådning, efter at Kongen havde forladt Norge, og Akershus Landsfengsel var overladt tyskerne. Finske fanger havde måttet evakueres på grund af Vinterkrigen. Haakon Sund fortalte om efterforskningen af brandsager. K. Kirchheiner sammenlignede danske og svenske regler om bedrageri og underslæb og kritiserede dansk straffelovs krav om berigelseshensigt, »for at «, som en uheldig arv fra Goos' berigelseslære. Senere praksis accepterer almindeligt forsæt.

Kampmann døde og mindedes i årgang 1942. Karl O. Christiansen skrev om kriminelle levnedsløb i Vridsløselille ud fra sondringen mellem akutte og kroniske kriminelle efter længden af mellemliggende kriminalitetsfri perioder, og overlæge Paul Reiter, Herstedvester, om psykopaterne, »de karakterologiske Vanskabninger «, hvortil han henregnede 3-5\% af befolkningen, og som han fandt det næsten umuligt at helbrede, selvom han ikke udelukkede spontanpacificering hos de ældre og ikke opgav terapeutisk behandling. Hans Chr. Kjorsgaard gengav fra det kriminalbiologiske institut i Hamborg frygtelige historier om falske selvanmeldelser, bl.a. om en mand, der tilstod flere mord og ca. 500 indbrud for at komme ud af koncentrationslejr, hvor han havde siddet i 6 år. 
Ud fra hjertevarm humanitet og venlig fasthed skrev Nissen om fængselsmandens personlige forhold til fangen, i hele tidsskriftets historie har jeg ikke set en ædlere repræsentant for fængselsvæsenets humanisering. Granfelt fortalte, at en lov om unge forbrydere, der knæsatte opportunitetsprincippet og gjorde det lettere for unge at opnå betinget dom, var vedtaget straks efter Vinterkrigen, men ikke kunne træde i kraft på grund af den næste krig. Waagensen redegjorde for organisatoriske ændringer i personundersøgelser med henblik på betinget dom og senere hjælp til løsladte; man veg tilbage fra at inddrage arbejdet under staten. Göteborgs politimester Ernst Fontell klagede over, at det var for let at stjæle, bl.a. var låse under al kritik, så nu havde politiet åbnet et rådgivningsbureau. Agge skrev om mened, der ikke blot hindrer statslige myndigheder i at fungere, men endog sætter publica fides i fare. Uden kommentarer refererede Waagensen fra Blätter für Gefängniskunde artikler om straf og fængsler i Generalguvernementet Polen, hvor bespisningen af fangerne frembød vanskeligheder, om den dalende kriminalitet i Tyskland efter magtovertagelsen og om den alt for lille arbejdsydelse fra fangerne i de tyske fængsler.

I årgang 1943 blev Stjernberg afløst af Bergendal som svensk redaktør. Størst indtryk gør Honkasalo: »Krigets inverkan på brottsligheten i Finland«. Modsat den voldsomme stigning i kriminaliteten ved Frihedskrigen i 1918, præget af »det hat, som ... länge hade sönderslitet vårt folk«, viste Vinterkrigen en klar nedgang, delvis fordi den mandlige ungdom var under fanerne, men også på grund af det totale folkelige sammenhold. Også under den nye krig tydede intet på, at »vårt folks moraliska styrka vore på upphällningen«. I et andet vægtigt finsk bidrag fortalte Verkko om kriminalstatistikkens fødsel i Frankrig og Belgien, særlig Quetelet; det aldrig afgjorte spørgsmål var, om det forhold, at kriminalitetens niveau var stort set ens fra år til år, talte for determinisme, hvilket Quetelet nærmest afviste, idet individet handlede frit, selvom massen var konstant.

Med mange tabeller gennemgik Gunnar Dahlberg fra »Statens rasbiologiska institut « livsrisikoen for at blive dømt for forbrydelser; risikoen er størst for de yngste mænd; er man blevet 50 som ustraffet, er man næsten sikker på at forblive det livet ud. Sverker Groth skildrede den svenske ungdomskriminalitets udvikling i mellemkrigstiden, stigning hvert år, men et lille fald 1939-1940, vel på grund af de militære indkaldelser. Överdirektör Hardy Göransson gennemgik en aktuel debat om straffeteorier - generalprævention og gengældelse skulle hindre specialpræventionen i at løbe løbsk - og afskaffelse af cellestraffen, hvor fængselsfolk advarede mod den ødelæggende smitteeffekt af totalt fællesskab mellem fangerne. Karl O. Christiansen, der samme år i forening med bl.a. Hurwitz stiftede Dansk kriminologisk Selskab, som fik afgørende betydning for Dansk Krimina- 
listforenings senere udvikling, fulgte sin artikel fra 1942 op med de samme 126 fangers kriminelle milieu, hvor han fastslog de kolossale andele af psykopater, $11,4 \%$ af de akut og 37,4 \% af de kronisk kriminelle; ægteskab kunne have en gunstig virkning på de kronisk kriminelle, medens de erhvervsmæssige forhold var elendige for begge grupper; om kriminaliteten eller de defekte sociale forhold kom først, var uvist. Borgsmidt-Hansen skildrede sikkerhedsforvaring, som modsat arbejdshus aldrig blev en succes, og spurgte, om det var de forkerte, der idømtes denne sanktion. Oluf Emborg analyserede domme om bordel; jeg noterer, at den sippede eufemisme »massageklinik« allerede da var kendt. Nissen kaldte hjælp til fangernes familier en samfundsopgave, som hjælpeforeningerne ikke havde mulighed for at løse.

Fra årgang 1944 overtog direktør for fængselsvæsenet Hans Tetens den ledige danske plads i redaktionen. Gustaf Birch-Lindgren og Gunnar Rudstedt fortalte om den nye svenske forvarings- og interneringsanstalt i Hall, desværre præget af krigstidens prisstigninger; »givetvis « var der ikke indvendigt nøglehul i cellerne, og da en fange i Norrköping var undsluppet igennem en åbning på $16,5 \mathrm{~cm}$, var afstanden mellem jerntremmerne $14 \mathrm{~cm}$. Trods krigen var der indført reformer i Finland, bl.a. var prøveløsladelsesreglerne mildnede (Granfelt). Nissen mindedes den afdøde generalsekretær i den internationale fængselsforening Jan Simon van der Aa, hvis sproglige kunnen var så stor, at han talte dansk ved en højtidelighed i Oslo. Han afviste forvaring efter stive kriterier og krævede individuel bedømmelse, gik imod det dobbeltsporede system, hvor strafafsoning fulgtes af forvaring, samt beklagede skærpelove fra 1942, som fyldte fængslerne med førstegangsdømte.

Worm fortalte om en studierejse i 1936 til alle engelske Borstalinstitutioner, hvor fangerne var placeret efter deres særpræg, og en god »Association « gav støtte til og førte tilsyn med de prøveløsladte, samt beklagede de traditionelle fængslers ledende ansattes dårlige muligheder for at påvirke fangerne. Læge Axel $H$. Arnfred beskrev en sag, hvor en akut sindssyg havde slået fire kvinder med en økse, bl.a. sin moder, som dræbtes; han var nu helbredt fra sin psykose, men hvornår kunne han løslades? Gribende var lægerne P. Dickmeiss' og Ib Ostenfelds beretning om to incestsager (moder og søn, som hun på grund af bortadoption først fik forbindelse med, da han var 15 år; broder og søster) på grund af exceptionelle psykologiske forudsætninger. Ubetinget straf var ufornøden. Broderens lange tilståelse - han var den aktive i forholdet og havde forsøgt selvmord var af diskretionshensyn gengivet på fransk!

I årgang 1945 opdelte Karl O. Christiansen forbrydelserne efter, om der forelå tillidsbrud. Mange tillidsbrydere havde sociale tilpasningsvanskeligheder; de 
idømtes mange, men korte straffe, de var sleske, ofte psykopater, og alt prellede af på dem. Fra Herstedvester fortalte overlæge Georg Stürup og Karl Johan Ebbe om behandling af psykopater og foretrak tidsubestemt forvaring frem for tidsbestemt psykopatfængsel; mange lod sig frivilligt kastrere; jo mere human behandling, des lettere var det at komme ud af det med de vanskeligere elementer. $\varnothing_{j-}$ vind Hardeng ønskede en psykopatanstalt i Norge, hvor der var for mange psykopater i tvangsarbejdsanstalter og fængsler. Reidar Sveen skrev om ildspåsættelse og seksualitet og foreslog mentalundersøgelse i brandsager, selv når motivet syntes økonomisk. Almquist nævnte et svensk reformforslag om fuldbyrdelse, f.eks. frigang inden prøveløsladelse, men advarede imod hovedkulds overdrevne lettelser, da det var svært at slå bak. Arvelo omtalte med stolthed omfattende reformer i Finland selv i krigstid.

Sidst i årgangen skrev Johs. Andences om det norske retsopgør, bl.a. problemet om Grundlovens forbud mod tilbagevirkende straf og de store bøder og erstatninger. Nissen skrev om Quislingregeringens hårrejsende love, værst vel ved at sikring kunne besluttes af en politimand alene på mistanke om bl.a. politiske overtrædelser som f.eks. propaganda for kongehuset, og om de nye love for retsopgøret; en detalje: hvis en N.S.-mands hustru selv havde udvist en national holdning, kunne hendes halvdel af fællesboet ikke inddrages. P.M. Sachs skrev om det danske straffelovstillæg, bl.a. om genindførelsen af dødsstraf og om handlinger begået inden 29. august 1943, hvor der stadig var en dansk regering. Og så havde Haack for sidste gang læst Monatsschrift für Kriminalbiologie und Strafrechtsreform, nu var det slut med de tyske tidsskrifter.

Almquist, født 1860, udtrådte af redaktionen i årgang 1946 og blev efterfulgt af Göransson. Hartvig Nissen døde og fik en enestående varm nekrolog af Kyhn Gløersen; den store humanists testamente var brochuren »Straffen og landssvikerne«, hvor han talte for de dømtes genrejsning og genoptagelse i arbejdslivet efter udstået straf. Nu fyldte den svenske reform tidsskriftet, Schlyter skrev om fuldbyrdelsesreformen med nøgleord humanisering og individualisering, tidligere prøveløsladelse og overførelse til åbne fængsler; Bergendal skrev om ansvarslæren og de enkelte forbrydelser, bl.a. de komplicerede embedsforbrydelser, ophævelsen af religionsforbrydelserne og forslaget om straf for »hets mot folkgrupp«; Carl-Henrik Ericsson skrev om arbejdsdriften, hvor man skulle vælge det fag, som gav fangen gode fremtidsudsigter og styrkede selvtilliden, Gunnar Thurén om det blomstrende idrætsliv i ungdomsfængslet Skenäs. Verkko skrev med overbevisende statistiske tabeller om barnemord i 1700-tallet og sammenhængen mellem rugpris og tyverier i 1800-tallet. Arnfred skrev om endnu en ung sindssyg øksemorder, og læge Else Nordbek studerede 256 oligofrene forbrydere på den 
Kellerske Aandssvageanstalt; de begyndte tidligere i puberteten end normale og begik flere brandstiftelser og sædelighedsforbrydelser mod børn. K. Leudesdorff og Vagn Skriver skrev om forsorgsarbejdet for danske fanger. Krigen afspejledes $i$ et nyt forslag fra Pella om at kriminalisere angrebskrig, i en anmeldelse af Jørgen Trolle: Syv Maaneder uden Politi om København i den politiløse tid, i et nødråb fra Axel Hye-Knudsen om de fortvivlede pladsforhold efter de af modstandsbevægelsen iværksatte ca. 15.000 interneringer efter befrielsen og en artikel af vicefængselsinspektør Bent K. Paludan-Müller, under krigen selv politisk fange; hans kritik af de miserable venteceller inden afhøring, »skabene«, og de elendige bogsamlinger gør indtryk.

Arvelo afløstes i årgang 1947 som redaktør af Verkko, der også mindedes verdens ældste statistik for voldsforbrydelser, det svensk-finske tabellverk fra 1748. Gösta Ringius skrev om detaljeret undersøgelse af dømte med over 6 måneders straffetid med henblik på anbringelse i den rette anstalt. Thorsten Sellin optrykte et foredrag i Dansk kriminologisk Selskab om kriminologi og etiologisk forskning, heri den gode pointe, at vi kan takke forbryderens ekstreme adfærd for vor viden om menneskesjælen. Johannes Halvorsen og Tetens skrev om behandling af de dømte norske og danske landssvigere. Begge lande frygtede de intelligente politisk skolede fangers påvirkning af de svagt udrustede, hvorfor man i Danmark afstod fra internt fangeselvstyre; det store fangetal, $19.000 \mathrm{i}$ oktober 1945, medførte brug af tyskernes lejre, da fængslerne ikke kunne rumme alle.

Carl Aude-Hansen undsagde progressionssystemet og nævnte det penible spørgsmål om fangernes ukontrollerede samkvem med ægtefæller og kærester, hvilket kunne føre til, at børn blev sat i verden, som fangerne ingen mulighed havde for at forsørge. Aage Hansen skrev om ungdomsfængslets første ti år og fremdrog Schlyters manende ord: »De skal ikke interessere Dem saa meget for, om der kommer nogle i Ungdomsfængslet, som ikke skulde have været der; men De skal passe paa, at der ikke er en hel Del, der gaar uden om Ungdomsfængslet, og som burde have været anbragt der.« Chr. Givskov skrev om de amerikanske training-schools. Theodor Petersen skrev om strafudmåling, man må ikke for de ubestemte domme glemme de mange traditionelt afgjorte sager; det er ingen eksakt videnskab, han spurgte ved frokostbordet i byretten, om en hæderlig underofficer, der havde gennemtævet en ualmindelig vanartet dreng, skulle straffes for vold med bøde eller hæfte. Fem barnløse dommere voterede for bøde, fem med børn for hæfte! Når dommeren var i tvivl, skulle han vælge den strenge eller den milde løsning, men ikke forfalde til en mellemløsning. Karl O. Christiansen anmeldte Louis le Maires disputats om kastration. 
Hovedredaktøren Haack, den sidste af grundlæggerne fra 1913, døde og blev mindet af Hurwitz i årgang 1948. Den danske psykiater Hjalmar Helweg anså $i$ sin studie over Hitlers mentalitet ikke denne som sindssyg, men - som også den norske psykiater Ingiald Nissen - som psykopat af den selvhævdende type med hysteriske træk. Hitler skabte ikke Tyskland, men Tyskland ham, i et sundt samfund var han blevet sat på plads. Bortset fra Hitler var interessen for Tyskland ophørt, et belgisk, et italiensk og et amerikansk tidsskrift blev refereret, men ingen tyske.

Rudstedt og den senere danske justitsminister Helga Pedersen havde besøgt amerikanske fængsler; hun havde fravalgt de dårligste institutioner, fremhævede de store fangetal og kritiserede, at dansk kriminologi kun interesserede sig for psykopaterne, men ikke den store gruppe; han nævnte både de mørke sider, andengenerationsindvandrernes store kriminalitet, og de snusfornuftige økonomiske argumenter for mildhed - en fangedag i et federalt fængsel kostede 1,32 \$, en dag i probation kun 9 cent. Ørnulv Ødegård talte om moral og personlig ansvarlighed fra psykiatrisk synspunkt og hævdede, at alle følelser havde deres ret, også vreden mod forbryderen; han afviste Freuds tese, at det etiske og sociale kun hørte hjemme i en overbygning. Stürup skrev om den psykiatriske fangeobservation og $H$. Worsaae Petersen om det nye åbne fængsel Nørre Snede. Fra Sverige skrev Ericsson om arbejdsdriften, Tore Strömberg om det stadig store problem förskingring og Bertil Persson om det praktiske problem, hvornår en rattfyllerist »fører« køretøjet. Karl O. Christiansens recension af Hurwitz' håndbog om kriminologi varslede emnets voksende betydning.

\section{1949-1978}

Den store ændring i tidsskriftets historie indtraf i 1949. Hurwitz blev hovedredaktør, også af navn, med redaktion i København. Haakon Sund erstattedes af Andenæs. Tidsskriftet blev medlemsblad for alle nordiske kriminalistforeninger og fik med et slag flere hundrede nye abonnenter, og i denne forbindelse indtrådte retsmedicineren Gabriel Langfeldt, Oslo, og riksåklagare Maths Heuman, Stockholm, i redaktionen, der også fik to islandske medlemmer, højesteretsdommerne Thórdur Eyjólfsson og Jónatan Hallvardsson. Samtidig ændredes navnet til Nordisk Tidsskrift for Kriminalvidenskab eller NTfK som et udtrykkeligt signal om, at indholdet ikke tilsigtedes at være snævert juridisk, men også spændte over penologi, kriminologi og kriminalpolitik. På en måde kom navnet i samklang med, hvad der allerede var tidsskriftets indhold, når man betænker reportagerne fra udenlandske fængsler og Karl O. Christiansens kriminologiske artikler. Modsat i 1913 vedgik redaktionen navn og gæld, idet årgang 1949 ikke blev den første, 
men den syvogtredivte. Schlyter sluttede sin hjertelige hilsen »Det bör betraktas som et lyckligt omen för denna tidsskrifts framtid, at ordet »straff« försvunnit ur dess titel« - ved tidsskriftets 50 års jubilæum i 1963 afslørede Hurwitz, at Schlyter havde gjort navneskiftet til en betingelse for fortsat svensk støtte til tidsskriftet.

Årgang 1949 voksede til 388 sider, hvor årgang 1947 kun havde 251. I stedet for få og lange artikler var der uhyre mange mindre, af hvilke jeg kun kan omtale de vigtigere. De lange statistiske beskrivelse af fængselsforhold udgik, men antallet af anmeldelser steg voldsomt, 46 bøger og tidsskrifter anmeldtes, og 7 yderligere tidsskrifter omtaltes. De enkelte anmeldelser var dog kortere end de få lange anmeldelser i det gamle NTfS. Modsat den tidligere tyske orientering havde især Hurwitz læst en mængde engelsk og amerikansk litteratur. Schlyter fyldte 70, blev hyldet og lykønskede selv den danske forening med de første 50 år. Erik Solem, stor som dommer og forfatter af en afhandling om Holberg som jurist, døde. Vigtige emner blev behandlet fra flere lande, lægens tavshedspligt af Ketil Motzfeldt, le Maire og Inkeri Anttila - det syntes, som om reglen var gennemhullet af flest undtagelser i Danmark Le Maire skrev desuden om retsvildfarelse; han afviste sondringen egentlig/uegentlig retsvildfarelse, roste et svensk forslag, som ville udvide adgangen til straffrihed for undskyldelig retsvildfarelse, og hånede domme med dissens eller forskel mellem instanserne. Lægen Erik Strömgren talte for narkoanalyse (»løgnedetektor«), også over for sigtede, dog kun ved frivillighed, og kun de for sigtede gunstige oplysninger kunne videregives, men Jørgen Trolle svarede skarpt, støttet af Stürup, at hvis apparatet brugtes, skulle alt frem i lyset.

Trolle havde selv et bidrag om straffen for forbrydelser begået af gamle og anbefalede en generøs fortolkning af tilregnelighedskravet og gerne mildere straf. Franz Marcus skrev om forbrydelser mod menneskeheden pådømt i den britiske zone i Tyskland, bl.a. en sag, hvor 3 marinedesertører, der 5.-6. maj var gået over grænsen til det befriede Danmark, men af danske var bragt tilbage til skibet, blev henrettet for faneflugt 10. maj 1945! Den svenske interneringsnämnds praksis blev skildret af $B$. Brandt; de ubestemte domme synes ikke at have noget formål, da næsten alle kun blev tilbageholdt på mindstetid. Omvendt hævdede overlæge Thorbjørn Kjølstad, at sikring anvendtes for lidt i Norge, alt for mange recidiverende tyve fik deres 90 dage, hvorefter de havde »gjort opp« med samfundet og atter gik ind i forbrydergeledderne. Filosoffen Åke Pelzäll var skuffet over, at strafbegrebet endnu ikke var afskaffet. Et fint nyt NTfK.

Årgang 1950 bragte som velkomment nyt »kronik« med små nyheder fra alle nordiske lande. Efter de mange specialpræventivt prægede årgange fulgte Andenæs: »Almenprevensjonen - illusjon eller realitet?«, en af de vigtigste artikler i 
tidsskriftets historie. En god pointe, almenpræventionen skifter efter hvilke overtrædelser den gælder, for en gangs skyld hørte vi om de mange små politiovertrædelser; der var også væsentlige bemærkninger om betydningen af straffens størrelse. Hertil knyttede sig to danske bidrag om strafudmåling, først Hurwitz' anmeldelse af von Eybens disputats, som antydede et takstsystem efter objektiv grovhed såsom det stjålnes værdi og forstraffe, men også kravet om lighed, næsten retfærdig gengældelse, dernæst P.M. Sachs' afhandling, hvor han særlig påviste en tendens mod mildhed, »ein Zug zur Milde«, i enhver strafudmåling over tid. Thórdur Eyjólfsson skrev om de strenge islandske regler om administrativ frihedsberøvelse; Justitsministeriet havde vid adgang til at påstå umyndiggørelse, en umyndiggjort kunne indlægges imod sin vilje; Island havde fortsat en lov om spedalskhed af 1898 og 1909. Verner Goldschmidt besøgte Danmarks Riges yderste udpost i Thule; få overtrædelser og meget milde reaktioner.

Paavo Hiltunen behandlede det penible spørgsmål om tidligere straffedommes betydning for skyldspørgsmålet; principielt forkasteligt, men i praksis ikke til at få livet af. Kai von Fieandt skrev om finske ungdomsforbrydere; de adskilte sig ikke fra normalpopulationen i intelligens, derimod nok i skolepræstationer. Ragnar Kolstad bagatelliserede filmen »Gategutter «s kriminogene betydning; nok havde unge tyve efterlignet filmens fremgangsmåde, men tusinder havde set den uden at stjæle. Langfeldt kritiserede de norske utilregnelighedsregler og mente, at Quisling burde have været mentalundersøgt; kriteriet »varig svekkede sjelsevner « var håbløst. Karl O. Christiansen skrev om den danske kriminalitetsudvikling, op under krigen, ned efter krigen, samt anmeldte et amerikansk værk, som bestred den populære opfattelse om den lave kvindelige kriminalitet. Den hjertensgode tyske kriminolog Rudolf Thieme, som havde fået et nyt liv i Danmark - midlertidigt også i Sverige som landflygtig i anden potens - døde. Og som det mest bizarre bidrag psykiateren Max Schmidts artikel om tatovering af især prostituerede kvinder; de af ham beskrevne tatoveringer nær genitalia kunne han næppe have beset uden næsten blufærdighedskrænkende adfærd!

Granfelt, finsk redaktør siden 1925, fratrådte i årgang 1951, afløst af professor Bo Palmgren. Krabbe og Skeie døde. Vægtigst var Vilhelm Auberts retssociologiske studie om 72 næringsdrivendes holdning over for nye norske næringsretlige straffebestemmelser. Alle krævede lovlydighed in abstracto, men nærmere udspurgt undskyldte de næsten alle overtrædelser, hensynet til fortjenesten var det første hensyn. »Kan det kombineres med bestemmelsene, så er det bra.« Von Eyben iagttog en tendens mod brug af retslige standarder i kriminalretten, bl.a. illustreret ved dolus Alexanderson, »forsætlig god tro«, og sagesløsbegrebets forskellighed i Bredgade og Nyhavn, og tilkendegav sin manglende sympati for den, 
der slår op i straffeloven for at konstatere, om han er på den rette side af det strafbares grænse. Han blev hårdt kritiseret af Trolle for sin »Regel-Nihilisme«.

Hurwitz fastholdt mod von Liszt, som han ellers hyldede, det værn for lovovertræderen, som ligger i den ved dom fikserede straffetid. Le Maire skildrede sager, hvor de upåvirkelige værste mordere trods mental afvigelse ikke blev sat i forvaring, men idømtes livsvarigt fængsel, men omvendt talte statsadvokat $K$. Kirchheiner mod ubestemte foranstaltninger efter små overtrædelser, værst en sag om 13 års anbringelse på sindssygehospital efter tyveri af $25 \mathrm{kr}$. H. Bahr gennemgik den nye norske beredskabslov bl.a. med mulighed for dødsdom; det mest vidtgående forslag, en forræderidomstol som eneste instans, hvis dom kun kunne gå ud på døden eller frifindelse, der ikke udelukkede efterfølgende tiltale ved anden ret, blev ikke gennemført. Ivar Strahl skrev om bødestraffen, bl.a. med den gode pointe, at trods næsten fuldstændig afskaffelse af bødeafsoning i Sverige blev lige så mange bøder betalt i Stockholm som i København og Oslo. Nye fængsler blev bygget, i Danmark Kragskovhede med kraftig anvendelse af det amerikanske klassifikationssystem (Carsten Rafael), i Sverige ungdomsfængslet Roxtuna som en reaktion på massive rømninger; bl.a. forsøgte man med kvindeligt personale som mere beroligende (Gunnar Marnell). I Trondhjem Tugthus fik forstanderen oprindelig ikke løn, kun skattefrihed, men i 1745 måtte man betale løn for overhovedet at få en ansøger (Kjell Bugge). Trolles fortrinlige Procedure $i$ Straffesager anmeldtes, alle unge anklagere bør læse den. Og så påviste $\mathrm{John} \mathrm{Ca}$ vanagh (Journal of Criminal Law and Criminology), at normale børn ikke tog skade af tegneserier. Det var da godt!

At årgang 1952 svulmede op til 508 store sider, skyldtes NTfK's nye rolle som medlemsblad for kriminalistforeningerne, idet forhandlingsgrundlaget for det tredje nordiske kriminalistmøde i København 3.-7. juni i 1952 fyldte de første tohundrede sider.

Den livlige, stenografiske debat - hele tyve tog ordet om færdselslovsspørgsmålet - kan læses i De nordiske kriminalistföreningarnas årsbok 1951-1952 (kort resumé i min Dansk Kriminalistforening 1899-1999). NTfK gengav også mødeprogrammet, herunder damernes program med lunch og mannequinopvisning hos Fonnesbech i København og besøg på et slot på Fyn, medens deltagerne besøgte Nyborg Statsfængsel og Søbysøgaard Ungdomsfængsel. For alle tre emner var der trykt et langt bidrag fra en hovedreferent samt indlæg fra korreferenter fra alle eller næsten alle øvrige lande, Island var ikke glemt.

Stürup var naturligvis referent til det første emne »Lægelig, psykologisk og psykiatrisk behandling af lovovertrædere«. Efter fine eksempler på en vellykket behandling på Herstedvester konkluderede han, at medens man hidtil i det retspsykiatriske arbejde havde lagt eftertrykket på en udskillelse af de grupper, der skulle fritages for den sædvanlige straf, måtte hovedinteressen 
nu lægges på gennemførelse af en terapi i et langt større antal tilfælde end hidtil tænkt. Torsten Erikssons synspunkter fremgår indirekte af hans referat af en amerikansk sag, hvor rutinemæssig undersøgelse af en stor dreng, der havde knust et par ruder, viste, at han havde planlagt at dræbe sin fader, hvorfor han idømtes en behandlingsdom! I Ödegårds indlæg var en tankevækkende parentes: »(Det kan hævdes prinsipielt at ingen som har begått en strafbar handling er helt psykisk normal, men i praksis vil en så konsekvent holdning ikke la seg gjennemføre).«

Honkasalo var referent på det andet emne »Tidsubestemt frihedsberøvelse som reaktionsform mod lovovertrædere, « paradoksalt, idet han som andre finner var skeptisk over for ubestemte domme af hensyn til retssikkerheden; uden at afvise dem krævede han maksimum fastsat af retten. De øvrige lande var mindre betænkelige. Jesper Simonsen sluttede stærkt: »Reformbestræbelser må rettes på at gøre frihedsbegrænsningen tåleligere og resocialiseringsbestræbelserne mere effektive. Det kan derimod ikke anerkendes som en berettiget konsekvens af frihedsgodet, at personer, der frembyder akut fare for alvorlige lovbrud, til given tid kan kræve frigivelse.«

Den islandske kriminaldommer Valdimar Stefansson var referent på det tredje emne »Den kriminalpolitiske behandling af berusede automobilister«, til alle tider et for den praktiske retshåndhævelse højaktuelt spørgsmål. Det store skisma var den faste promillegrænse, gennemført i Norge og Sverige, men ikke i de tre øvrige lande. Fire lande straffede med korte frihedsstraffe, Island derimod med bøde i førstegangssager, ikke efter principielle overvejelser om frihedsstraffens skadelighed, men fordi der ikke var fængselsplads nok. P.M. Sachs drøftede betinget dom, endog betinget førerretsfrakendelse.

Resten af årgang 1952 var præget af vægtige norske artikler. Riksadvokat $A n d r$. Aulie skrev om sjælelig »force majeure«, en indre, uimodståelig trang. I de fleste sager idømtes forbryderen almindelig straf, som i »chokolademordsagen«, men i ekstreme tilfælde skete frifindelse, som i en sag om en frihedskæmper, der efter tidligere tortur angav ikke blot sin gruppe, men et stort antal yderligere hjælpere (i Danmark er afsagt en tilsvarende dom). Leivestad påviste, at lægdommere, der havde medvirket i både jury og meddomsrett, ikke i nævneværdig grad foretrak det ene frem for det andet system. Nils Christie bragte en sociologisk studie af norske fangevogtere, der havde udført tjeneste i tyske tilintetgørelseslejre i Nordnorge; fælles for alle var stærke autoritære træk, og de Quislingtilhængere, der meldte sig af ideologiske grunde, havde udvist en værre adfærd end de økonomisk motiverede og manglede evne til at identificere sig med de serbiske fanger.

Anders Bratholm beskrev »probation« i U.S.A., bl.a. det retssikkerhedsmæssige problem, at tiltalte ikke kan krydsforhøre dem, der har afgivet ugunstige udtalelser om ham, hvilket i Williams-sagen medførte dødsdom (Williams blev dog benådet). Kyhn Gløersen skildrede 100 års norsk fængselsvæsen, og overrettssakfører Arvid Fossum fortalte, sekunderet af Andenæs, om den 64-årige, der for tyveri havde afsonet idømte straffe på i alt 28 år, og efterlyste en mulighed for betinget dom, når en gammel tyv begår en mindre forbrydelse efter flere års straffri 
vandel (jeg afbrød selv som dommer med held en kriminel karriere ved en betinget dom i sag nr. 28, da der var håb om bedring). Sten Tengelin (svensk) kritiserede ensidigheden i Edwin Sutherlands berømte »White Collar Crime«, og politiadvokat Jørgen Smith, senere min dygtige og venlige chef som politimester i Rudkøbing, påviste på grundlag af praksis, at samtykke til udstedelse af dokumenter $\mathrm{i}$ andenmands navn, her usandfærdige papirer om varers påstået østtyske oprindelse, ikke udelukkede straf for dokumentfalsk. Donnedieu de Vabres og Tulenheimo døde og blev mindet.

I årgang 1953 kunne man læse Hans Kelsens forelæsning »Hvad er retfærdighed?«. Han anså alle værdidomme for subjektive og kun opnået ved følelserne, kun gyldige for den, der dømte og kun relative. Kelsen, der særlig analyserede Platons og Jesu lære, opgav at besvare spørgsmålet, men valgte selv subjektivt den retfærdighed, under hvis ægide videnskab, sandhed og oprigtighed blomstrede, tolerancens retfærdighed. Gunnar Mortensson beskrev en psykiatrisk undersøgelse af 255 danske landssvigere; nok var der mange psykisk afvigende, men disses hyppighed svarede til befolkningen, og den udbredte opfattelse i 1945, at landssvigerne var psykopater og intelligensdefekte, blev ikke bekræftet. Derimod fandt Ragnar Christensen hos norske landssvigere overrepræsentation af sindslidende, især paranoikere, jfr. Hitlers eget paranoide præg. Ulrik Borch efterlyste en norsk kriminologisk undersøgelse af landssvigerne som Karl O. Christiansens danske.

Nils Beckman gennemgik et forslag til Brottsbalk. Både den gifte og den ugifte moder fik strafnedsættelse for barnemord; svangerskabsafbrydelse var fortsat strafbar, også for kvinden; brugstyveri blev straffet som tyveri, når gerningsmanden ikke havde leveret tingen tilbage; et gammelt stridspunkt blev løst, idet injurianten fik ret til at føre sandhedsbevis jfr. under årgang 1918. Johan Bremer fortalte om efterundersøgelse af legalt kastrerede personer i Norge 1935-1949, mindre optimistisk end den tidligere danske undersøgelse. Han forventede, at kastration i fremtiden næsten kun blev taget i brug over for åndssvage. Den svenske overlæge Torsten Sondén skrev en lang beretning fra en studierejse til Italien. Roccos love fra 1930 gjaldt fortsat. Behandlingen af voksne fanger manglede helt individualisering, og den psykiatriske behandling var utilstrækkelig, derimod var behandlingen af mindreårige fortrinlig; med varme skildredes en »drengerepublik« under en katolsk præsts milde ledelse. Den amerikanske professor Philip Jessup gennemgik de forgæves bestræbelser på at skabe en international kriminaldomstol og de formidable politiske hindringer. Dansk kriminologisk Selskab fejrede et dobbeltjubilæum, 50 møder på 10 år. 
Kyhn Gløersen efterfulgtes i årgang 1954 som redaktør af Johannes Halvorsen. Goldschmidt beskrev den nye grønlandske kriminallov, som kodificerede den tidligere uskrevne milde og stærkt individualiserende praksis, der næsten ikke kendte fængsel, men anvendte bl.a. forvisning, forbud mod at opholde sig på det sted, hvor forbrydelsen var begået. Andenæs indledte en debat, fulgt af Hurwitz, Stang og Trolle, om en omstridt vedtagelse i Stortinget, hvorefter forbudet mod at drage medlemmerne til ansvar for deres ytringer i tinget også omfattede en sag kun om mortifikation, hvilket Andenæs vendte sig imod; Stortinget fik det sidste ord, idet Høyesterett i Rt. 1957,33 afviste et sådant søgsmål, fulgt op i Danmark 1965. Aubert skrev i forlængelse af Sutherland om »White Collar Crime«, hvis problem er, at gerningsmændene hverken af sig selv eller af samfundet opfattes som forbrydere; der afspejledes en kamp mellem et traditionelt og et nyt politisk statussystem. Sjefsinspektør Øystein Gjelsvik fulgte op med en skildring af kontrolordninger i næringslivet og de traditioner, der modvirker lovlydighed; når konkurrenterne overtræder loven, gør man det også selv.

Leivestad gennemgik den stramme norske lovgivning om lægers tavshedspligt og udtrykte sympati for den danske regel, der underkaster spørgsmålet om vidnefritagelse en konkret afvejning. Hye-Knudsen refererede tre sager, hvor løsladte forbrydere begik drab, men tilføjede, at disse tragedier kun kunne undgås, hvis man aldrig løslod disse fanger, hvilket var utænkeligt. Læge Erik Kiørboe beskrev epileptikeres kriminalitet, ofte præget af bortforklaring af ordinære forbrydelser. Kurt Stillschweig drøftede straf for forbrydelser begået i beruselse, især problemet forsæt og vildfarelse. Verkko spurgte, om den finske voldskriminalitet skyldtes, at finnerne var halvprimitive.

Verkko døde, et trist tab, mindedes i årgang 1955 og efterfulgtes af Honkasalo, hvem ellers? Bergendal udtrådte, erstattet af Agge. Jacob Molland og Einar Bakke fortalte om de norske regler om spirituskørsel. Allerede ved en promille på 0,5 var den »biologiske tærskel« overskredet, til gengæld var andelen af ulykker, der skyldtes alkohol, meget ringe i forhold til den samlede mængde ulykker. Jørgen Smith havde to retshistoriske artikler, først om større sager om svig og uredelighed, derpå om overtrædelse af skatte- og afgiftslovgivningen og den manglende folkelige fordømmelse heraf, selv efter at Kongen i 1753 og 1766 havde instrueret biskopperne om at lade præsterne prædike om toldsvigens syndighed efter Guds og Kongens lov. Statsadvokat Niels Parelius beskrev udmålingspraksis i norske drabssager, bl.a. den eneste påtaleundladelse efter et medlidenhedsdrab under ekstremt formildende omstændigheder, en mand på 68, der dræbte sin sindssyge datter for at spare hende for lidelser ved anbringelse uden for hjemmet. 
Bistået af Strahl og Hurwitz skrev den franske professor Marc Ancel om den nye straffeteori défense sociale, rettet både mod klassisk gengældelseslære og positivistisk determinisme med afskaffelse af straf; man ønskede en humanistisk og moralsk strafferet. Christie interviewede 98 varetægtsfanger om deres forventninger til deres egen dom - de fleste bedømte den korrekt - og hvad de ville have idømt sig selv, hvis de havde været dommer; formueforbrydere anerkendte i højere grad systemet end de stærkt negative løsgængere, og man foretrak (kortere) straf frem for (længere) behandling. Og så fortalte anklageren i den danske »hypnosemord «-sag, statsadvokat Erik Bech, den fantastiske historie om bankrøveren og dobbeltmorderen, der hævdede at være hypnotiseret til sin forbrydelse af den medtiltalte, der idømtes livsvarigt fængsel »for påvirkning af forskellig art, herunder hypnotisk påvirkning«.

Årgang 1956 var som de øvrige i denne periode fyldt med gode domsreferater, her Leivestads om norske domme i 1954 og 1955. Christie efterlyste forskning om recidiv og trøstede med, at i det mindste løsladte drabsmænd aldrig recidiverede. Modsat Karen Berntsen og Karl O. Christiansen, der af specialpræventive grunde ønskede korttidsstraffen afløst af især betingede domme, påpegede Aude-Hansen, at en kort straf kan være den rigtige reaktion mod intermitterende kriminelle, der igennem livet har en del sager, men også lange kriminalitetsfri mellemperioder. Ulf Lindh beskrev åtalsprövning, tiltale i mindre sager kun når »ur allmän synpunkt påkallat«, som den bedste måde at udskille atypiske sager på; indskrænkende fortolkning synes bortvalgt som alternativ udvej.

Politiadjudant Egil Breen behandlede det evige problem om straffens etik; af deterministiske grunde forkastede han retfærdighedsargumentet, men accepterede præventionshensynet, dog at straffen ikke må overstige, hvad retfærdigheden kræver, så slap den alligevel ind. Jørgen Smith skrev om overtrædelser af den økonomiske restriktionslovgivning i krigs- og krisetider og om White Collar Crime, hvor han delvis i opposition til Sutherland og Aubert fremhævede, at også underklassen kan begå disse forbrydelser, således overtrædelse af rationeringslovene og skattesvig. Endelig var der to bidrag fra livets afslutning. Helge Hoff afviste legalisering af medlidenhedsdrab, men accepterede betinget dom i ekstreme tilfælde, og prosektor Jørgen Voigt ønskede obduktion i flere tilfælde uden for København og refererede bl.a. en sag, hvor en kvinde, der tilsyneladende var død af naturlige årsager, var kværket af en yngre slægtning, der ville have hendes penge.

Årgang 1957 rummede oplæg til det fjerde nordiske kriminalistmøde i Oslo, to hovedemner og seks mindre emner. 
Høyesterettsdommer O.C. Gundersen var referent på emnet »Skattesvik som kriminalpolitisk problem«, Jørgen Smith, Inkeri Anttila og Hans Thornstedt korreferenter. Forholdene var meget ens, skattetrykket var steget til 15-20\% af indtægterne, en lignende del af indtægtsmassen blev unddraget beskatning i Danmark, Norge og Sverige, og hver anden skatteinspektion i Finland medførte efterbeskatning. Straffesager var sjældne, særlig i Norge var tilleggsskatt helt op til $100 \%$ af det unddragne skattebeløb en mere praktisk reaktion end en lille bøde. Gundersens retspolitiske løsning var ikke flere straffesager, men mere effektiv ligning, som måske endog kunne få homo economicus til at holde sig »så noenlunde innenfor lovens rammer«. Det andet hovedemne »Bör bestämmandet av brottspåföljden skiljas från avgörandet av skuldfrågan och möjligen även anförtros åt särskilda organ?« havde Strahl som referent. Han foreslog mulighed for opdeling af processen i to stadier; normalt skulle retten afgøre begge spørgsmål, men det skulle være muligt at inddrage behandlingsorganer med judicielt indslag til at tilpasse foranstaltningen, og fastsættelse af sanktioner på ubestemt tid behøvede ikke ske i selve processen.

De seks mindre emner var »Biltillgrepp« (Gustaf Persson), »Gruppeterapi og andre nyere behandlingsmetoder overfor lovovertrædere« (Stürup m.fl.), »Klientel- och behandlingsundersökningar som grundval för kriminalpolitiskt reformarbete « (Agge), »Behandling af beruselse på offentlige steder« (Sveinbjórn Jónsson), »Vilka åtgärder bör man träffa för att tillvarataga den förorättades ersättningskrav? « (Palmgren) og »Bruken av varetektsfengsel« (Bratholm). På én gang evige og aktuelle emner.

Af de øvrige bidrag i årgang 1957 var de vigtigste de lange beretninger om Rock'n Roll optøjerne i Oslo (Elg Elgesem og Knut Sveri) og nytårsoptøjerne i Stockholm (Carl Holmberg), hvor sociologiske undersøgelser viste, at forskellen mellem uromagerne og normale unge ikke var stor, bortset fra at en uforholdsvis stor del af de norske uromagere kom fra »broken homes«, og at de voldsomme stockholmere var mindre sensitive for, hvad andre tænkte om dem, og dermed havde en lavere tærskel af sociale hæmninger; den stadig voksende fritid var et problem i sig selv.

Honkasalo redegjorde for de seneste årtiers udvikling i den finske kriminalitet, især nedgangen $\mathrm{i}$ antallet af mord (51 i 1927, 39 i 1955) og drab incl. vold med døden til følge (224 i 1927, 71 i 1955); Finland var blevet normalt og roligt. Jørgen Remvig og Stürup gennemførte en indtrængende undersøgelse af døvstumme lovovertrædere, af hvilke der kun var 32 af en gruppe på ca. 1.200-1.500. Kun de få, der faldt uden for det intensive fællesskab mellem danske døvstumme, var kriminelle; her dominerede sædelighedsforbrydelserne, særlig hos de 5 i forvaringsanstalten. Som bilag til årgangen var vedlagt første hæfte af studien »Alkoholvaner og kriminalitet (Erik Christensen, Erik Jacobsen, Alvar Nelson og Max Schmidt).

Vægtigst i årgang 1958 var Andenæs' artikel om strafudmåling, til en vis grad et forsvar for takstsystemet og udmålingstraditionen; han krævede, at dom- 
meren klarlagde sig de emotionelle faktorer for udmålingen for at sætte dem under censur af forstanden og moralen. Modsat Hurwitz' indskrænkning af kriminologien til kriminalitetsfaktorerne inddrog Christie strafferetten og retssystemet som en del af denne; om mørketallet bemærkede han, at af ca. 20.000 efterforskede sager var der kun rejst tiltale i knap 3.000. Bo Gerle gennemgik en retspsykiatrisk efterundersøgelse af »mordbrännare« og fremhævede det lave recidiv og den så godt som ikke-eksisterende risiko for recidiv i samme forbrydelse. Sven Erkkilä skrev om selvmord blandt finske straffefanger; tallet var ikke højt, men der var triste eksempler på for sen indgriben over for selvmordstruede fanger.

Fængselspræst Erik Hindse-Nielsen og Hye-Knudsen anbefalede et perspektiv for igangsætning af et løsladelsesforløb for (i hvert fald nogle) livstidsdømte efter ti års afsoning. Med Storm P.'s ord er det svært at spå, især om fremtiden, men Karl O. Christiansen og Arne Nielsen forsøgte at beregne den fremtidige kriminalitet i de store fødselsårgange 1942-1946, også med inddragning af efterkrigstidens lette fald $\mathrm{i}$ kriminalitetshyppigheden, og forventede stigning også efter 1970, hvor de store årgange alle havde nået voksenalderen. Karl O. Christiansen og Lars Nordskov Nielsen havde desuden foretaget en stor undersøgelse af kriminelle under 18 år, der havde fået tiltalefrafald mod børneforsorg, den altovervejende reaktion i dansk praksis; det triste var det meget store recidiv, over $40 \%$. Den store fængselsreformator Margery Fry døde.

Den meget fine årgang 1959 var domineret af vicefængselsinspektør Vagn Kildemoes' $101 \mathrm{pp}$. lange skildring af Statsfængslet i Vridsløselille ved dets 100 års jubilæum, det fængsel, der ved bygningen ansås for at være Danmarks mønsterfængsel, bygget efter det strikte Philadelphiasystem, fanger med maske i streng adskillelse, senere lempet. Han beskriver fangernes liv, men også personalets på én gang hyggelige og afsondrede tilværelse, de vigtigste personligheder som Frederik Bruun, den første inspektør, og Ammitzbøll, inspektør i 39 år, overfyldningen og de dramatiske begivenheder under og efter krigen. Kongen besøgte fængslet straks efter bygningen, den fhv. justitsminister Alberti afsonede en stor del af sin fængselsstraf her, digteren Kaalund var i mange år den idealistiske overlærer etc. Læseren beklager blot, at der aldrig i NTfK har været at læse tilsvarende store beskrivelser om Botsfengslet og Långholmen.

Bortset fra denne afhandling og en studie af Niels Pape om 9 tilfælde fra retspsykiatrisk praksis, hvor tidligere akriminelle kvinder i klimakteriet havde begået meningsløse magasintyverier, var årgangen fyldt af vægtige norske bidrag. Bratholm beskrev benådning i kriminalretlig betydning som et i praksis uundværligt institut; han anbefalede det ikke flyttet bort fra Kongen i Statsråd, men afviste ikke et rådgivende nævn. Parelius skrev om Hetlesagen, der plagede Norge fra 
domfældelse i 1907 for et tvivlsomt drab via genoptagelse og frifindelse i 1943 til livsvarig billighedserstatning for den stadig levende dømte i 1959. Andenæs holdt en fornem gæsteforelæsning i Helsingfors om strafferet, vurderingsfri kriminologisk forskning og kriminalpolitik og sluttede med at tilslutte sig tanken om et nordisk kriminologisk forskningsråd; om de faktiske forholds betydning citerede han Golls bonmot: »Vi behøver bare at vide, at tyveri af en hest og forurening af drikkevand er de største forbrydelser i Arabien, for ligesom i et glimt at se det hele samfunds liv og forhold for os." Aulie advarede mod de mange gentagne påtaleundladelser og betingede domme, selv i grove voldssager, som han kaldte laissez-faire politik, ikke som en kompliment. Sveri beskrev rystende stor barnekriminalitet, begået i bander, »gjeng«; en fjerdedel af alle afslørede forbrydere var under 15 år, og vaneforbrydere begyndte i 12-13 års-alderen! Endelig skrev $K$. Erikssen om sovjetiske strafferets- og straffeprocesreformer, bl.a. opgivelsen af de værste analogiregler.

I årgang 1960 undersøgte fängelsepsykiater Achille Westling, Helsingfors, det triste fænomen, at de 48.628 børn, som under krigen 1941-1944 havde været opfostret i Sverige (samt 3.764 i Danmark), hvor de havde haft særdeles gode forhold, efter hjemvenden til Finland havde en højere kriminalitet end gennemsnittet; da effekten aftog over tid, antog han, at tilpasningsvanskelighederne efter hjemkomsten havde hovedskylden. Birgit Werner havde forsket i biltyveri i Sverige, hvor forbrydelsen var flere gange hyppigere end i Danmark, selv iberegnet den større automobilpark. I et langt bidrag beskrev overlæge Emma Vestergaard en indgående efterundersøgelse af 13 kvinder, udsat for incest af deres fædre; i de fleste tilfælde var forholdet dybt traumatiserende og havde bevirket langvarige neuroser og udtalte seksuelle konflikter.

Andenæs, Sveri og Ragnar Hauge samt Ola Nyquist og Strahl havde undersøgt mørketallet ved udspørgning af stud.jur.'er; omtrent halvdelen havde begået promillekørsel, især i Norge, og mange havde stjålet i forretninger. Efter statistiske undersøgelser konstaterede Karl O. Christiansen, Lise Møller og Arne Nielsen, at livsrisikoen for at blive straffet var $10 \%$ for mænd og $1 \frac{1}{2}-2 \%$ for kvinder, samt at risikoen var størst for aldersklasserne 18-20 år. Preben Wolf undersøgte recidivet med udnyttelse af så godt som alle kombinationsmuligheder og nåede det uventede resultat, at recidivet er omtrent det samme efter betinget som efter ubetinget dom, således at kriminalpolitiske konklusioner var vanskelige at drage. Hurwitz mindedes årets store døde, Schlyter, »den førende skikkelse i dette århundredes nordiske kriminalpolitik «, og psykiateren Hjalmar Helweg.

En af de vigtigste artikler i tidsskriftets historie må være Christie: »Reaksjonenes virkninger« $i$ årgang 1961. Han når det forbløffende resultat, at der ikke 
kan konstateres forskelle, hvilket må medføre skepsis over for brugen af lange, tidsubestemte foranstaltninger frem for en kortere straf, samt at den bedste virkning indtræder, når intet gøres; omvendt er han klar over, at samfundet ville gå i opløsning, hvis det aldrig skred ind mod lovbrud som i den politiløse tid i Danmark. Hvor finder vi balancepunktet? Heikki Mälkki havde undesøgt »påföljdseftergift«, hvor retten helt undlader at fastsætte en retsfølge; den ikke-finske læser er frapperet ved oplysningen om, at kun nogle, men ikke alle retskredse anvendte instituttet. Jan Björk skrev om den strafferetlige behandling af »missanpassad ungdom« i Schweiz. Finn Tofte fortalte om en opsigtsvækkende behandling i Horsens Statsfængsel, hvor man før lange samtaler med de forvarede indsprøjtede dem intravenøst med »narcodorm « for at trænge ind i deres psykiske struktur, naturligvis på frivilligt grundlag. Kaare Svalastoga gennemgik over 100 danske voldtægtssager sociologisk og konstaterede, at ikke blot gerningsmændene som forventet tilhører de laveste lag, men også de fleste ofre. Folke Wetter og den engelske fængselsmand Lionel Fox døde. Göransson og Heuman forlod redaktionen og erstattedes af justitieråd Nils Beckman og lagbyråchef Carl Holmberg.

I årgang 1962 fulgte indlæg til det femte nordiske kriminalistmøde i Helsingfors.

Inkeri Anttila stod for det første plenaremne »Åtgärder mot ungdomskriminaliteten sedda mot bakgrunden av kriminalitetens allmänna utveckling i de nordiska länderna under de senaste åren«. Der var tre korreferenter og mængder af statistiske oplysninger. Bortset fra Danmark var der stigning i alle lande. Sanktionerne blev derimod mildere, og forsorgsforanstaltninger anvendtes i stadig stigende omfang i stedet for straf. Det andet plenaremne »Avhør av mistenkte, tiltalte og vitner i straffesaker« var tildelt Andenæs, som bifaldt udviklingen henimod at betro afhøringen til parterne snarere end retten. Ved det vigtige spørgsmål, om anklageren eller forsvareren skal afhøre tiltalte først, tilsluttede han sig den danske ordning, hvor anklageren begynder, bl.a. stiller det forsvareren i en vanskelig stilling, hvis ting som er ubehagelige for tiltalte, kommer frem under hans afhøring.

Der var fire sektionsemner. Hye-Knudsen talte om livstidsstraffen og ønskede på ny nærmere regler for løsladelse af de dømte. Kyösti Jousimaa beskrev »Undersökning av omfattande brott på det ekonomiska livets område« og stillede kolossale krav til den ledende efterforsker, som skulle være uddannet i kriminalpolitiet, være jurist, fortrolig med økonomiske spørgsmål, forvaltning, bogføring og bankvæsen samt beherske finsk, svensk, fransk, tysk og engelsk etc. Han mente, at opregningen svarede til forholdene i praksis! Skyddskonsulent Börje Nyblom talte om »Tillsyn och annan eftervård efter kort frihedsstraff«; ingen kunne være uenig om det ønskelige i forsorg også for løsladte korttidsfanger, men det lød meget svensk, at han tildelte nykterhetsnämnden en stor rolle i denne efterforsorg. Endelig havde Knud Waaben et langt indlæg om »Den strafferetlige reaktion overfor truende personer«; han var ubehageligt klar over det næsten uløselige problem, at for sen indgriben kan medføre de værste konsekvenser, endog drab, men det kan skade at tage for hurtigt affære ved trusler fra nærtstående personer. En mulig løsning 
kunne være en omgående anholdelse efterfulgt af at lade sagen falde uden dom, når forholdene var blevet roligere. Den efterfølgende debat kan, desværre for sidste gang, ses i årbogen (kort referat i min bog fra 1999).

Blandt de øvrige bidrag i årgang 1962 vil jeg fremhæve Anttilas og Westlings store studie om udmålingskriterier, hvor de analyserede samtlige domme for flugt fra fængsler (strafbart i Finland), 342 over en femårsperiode. Da den strafbare handling udadtil var ensartet $i$ alle sager, afgav de store variationer i udmålingen et frugtbart undersøgelsesfelt; blandt de klareste differencer var, at kvinder straffedes mildere end mænd. Erik Bjerg Hansen vovede på grundlag af en dobbeltmordsag at antage mulighed for partiel psykose, modsat herskende dansk teori (Helweg og Pontoppidan), der fastholdt, at hele sjælelivet angribes. Kaj Arentsen og C.J. Hansen beskrev en gennemgribende ambulant behandling af kriminelle alkoholister. Svend Gram Jensen opsummerede flere års debat om dødsstraffens berettigelse. Agge erstattedes som svensk redaktør af professor Hans Thornstedt.

I årgang 1963 forfulgte Per-Edwin Wallén begreberne mord og drab igennem svensk ret fra middelalderen til Brottsbalken. Oprindelig er mord det hemmelige drab samt drab under brud på et særligt troskabsforhold (ægtefælle, herskab), men i det 19. århundrede bliver kriteriet det afvejede forsæt, »med berått mod«. De syv internationale kongresser om kriminalantropologi 1885-1911 blev skildret af Klas Lithner, der opregnede alle emner og udtog et pr. kongres, bl.a. Lombrosos sammenligning mellem homoseksualitet og medfødt forbryderiskhed; de har samme ejendommelige og umoralske psykologi og er neurotisk sygelige og uforbederlige. Overlæge Jan Sachs spurgte, om »psykopater « - han har afskaffet begrebet psykopati, derfor anførelsestegnene - kan behandles, og mente nærmest ja; han foretrak tidsbestemt særfængsel for tidsubestemt forvaring, da de forvarede kun tænker på deres frigivelse. Riksadvokatfullmektig Frithjof Gripne sammenstillede den stigende ungdomskriminalitet og den samtidige accelererende formildelse i reaktionerne, og Bratholm kom tæt på at give Gripne ret ved at indlæse en årsagssammenhæng, men ville dog ikke umiddelbart anerkende, at det ville være god politik at skærpe reaktionerne væsentligt. Christie modstillede en norsk og en siciliansk ungdomsgruppe og fremhævede de kriminalitetstruende faktorer for den norske »gjeng «, bl.a. at den ikke rummede piger eller kun piger med exceptionelt lav rang.

Årgang 1964 gav fem spændende artikler, to norske, en svensk, en finsk, en dansk. Andenæs nævnte i sit foredrag »Inntrykk fra amerikansk strafferettspleie« bl.a. angelsaksiske juristers stolthed over uberettigede frifindelser af processuelle grunde som en pris at betale for retssikkerheden. »Deres bedømmelse av frem- 
mede systemer bygger som regel på et solid grunnlag av uvitenhet. Det er således en vanlig forestilling blant amerikanske jurister at den kontinentale prosess pålegger den tiltalte å bevise sin uskyld.« Christie analyserede »edruelighetsnemndene« og dilemmaet ved at forene tvang og hjælp hos samme myndighed. Han accepterede, at der ikke gribes ind over for den »som rolig og fredelig skader seg selv, og bare seg selv, ved å drikke seg fra eiendom, helse og liv ... Det er vel kanskje også et spørgsmål om det representerer noe høyt ideal at det finnes tvangsinngrepsmuligheter overfor personer med lidelser som ikke blir andres."

Hans Klette gennemgik tre rattfylleriundersøgelser i Malmöhus län, bl.a. vanskeligheden ved tilbageregning, det gamle problem om, hvorvidt alkohol indtaget kort før kørslen har virket under kørslen. Som dansk må man være taknemlig for, at da vi indførte de faste promillegrænser i 1976, valgte vi formuleringen »under eller efter kørslen«, så det af Klette nævnte problem ikke opstod. Klettes tanker om at straffe passageren for medvirken til kørslen er heldigvis aldrig blevet dansk ret. O. Katila og P. Hellsten beskrev syv finske sager om drenge under 15 år, der havde begået mord (to rovmord) eller drab (fem tilfælde); de to mordere var følelseskolde, eksplosive psykopater. Flere ofre var drengenes fædre, og i disse tilfælde havde moderen $\mathrm{i}$ årevis været aggressiv mod faderen. Kriminalpsykolog John Andersson beskrev »Rock and Roll«-optøjerne i København 5.-10. august 1957 og en efterfølgende interviewundersøgelse af de anholdte 63 unge. De fleste havde kun indfundet sig for at overveje urolighederne, men ikke for at deltage selv, og den værste efterfølgende konsekvens synes at have været en negativ holdning over for ret og politi hos de mange, der blev anholdt og fik en bøde på typisk $100 \mathrm{kr}$. hver.

I årgang 1965 skrev Clas Amilon en lang beretning om franske fængsler, bl.a. den grundige differentiering i klassificeringsanstalten Fresnes, hvor alle med straffetid over 2 år overvåges og bedømmes efter en observationsperiode på 6 måneder. Rättschefen Holger Romander gennemgik den nu lykkeligt gennemførte brottsbalk, som dog ikke måtte bremse for yderligere nødvendige reformer; prøveløsladelse var allerede ved at blive overvejet på ny. Overlæge Bent Florian Sørensen refererede 22 domme om patologisk rus fra Retslægerådets praksis og understregede, at denne rus, modsat hvad mange tror, ikke er en uventet reaktion på et ringe kvantum alkohol, men en usædvanlig reaktion på høj spiritusindtagelse. B. Borup Svendsen forsvarede den af ham beundrede Stürup og Herstedvester mod »ubeherskede og groft fortegnede journalistiske og advokatoriske indlæg i dagspressen, både den populære og den mere seriøst debatterende«.

Karl O. Christiansen og Lone Pál undersøgte recidivet i Danmark 1933-1960, konstaterede som særlig karakteristisk efterkrigsårenes stærkt faldende recidiv- 
hyppighed og advarede imod ukritisk sammenligning af recidivprocenter fra forskellige år. Jan Vilgeus anbefalede tyveri fra automater straffet netop som tyveri, ikke som bedrageri, jeg er enig. Jørgen Smith beklagede dommernes tilbageholdenhed med igangsætning af sager om falsk forklaring i retten og mente, at mørketallet for denne forbrydelse måtte være meget stort. Donald Cressey, forfatter til »Other People's Money«, spiddede verbaliseringsprocessen hos den ansatte, der tilegner sig firmaets penge, $» j e g$ lånte bare «, og foreslog interne programmer til hjælp til sanering af de ansattes økonomiske problemer. Bratholm overvejede i »En snarvei til sannheten?« brug af løgnedetektor i strafferetsplejen, som han forkastede, bl.a. med frygt for konsekvenserne, hvis alle forbrydere blev afsløret, selvom han fandt det overdrevet, at der ikke ville være tilstrækkelig mange på fri fod til at bygge de fængsler, hvor resten af os skulle placeres. Også jeg må afvise løgnedetektoren. Jeg kan ikke stå for Sven Erkkiläs bemærkning om de finske drikkevaner, »alkoholen bör vara stark och förtäringen skall ske fort« (i en artikel om spirituskørsel i Helsingfors og Åbo).

I årgang 1966 skrev Eva Nordland om »Allmennprevensjon og disiplin i oppdragelsen« med udgangspunkt i en artikel af Andenæs. Hun gik ind for gruppeorienteret disciplin som et sidestykke til almenpræventionen og veg ikke tilbage fra lette straffe såsom en påtale, fratagelse af goder, som resten af gruppen nød godt af, og eventuelt et særlig opdrag for at genoprette den forvoldte skade. Andenæs selv havde to vægtige bidrag $\mathrm{i}$ årgangen. Sammen med Ragnar Hauge påviste han, at det var umuligt at få norske juryer til at domfælde for uagtsomt drab, særlig færdselsdrab, og sætte forbryderstemplet på en brav mand på grund af et øjebliks tankeløshed eller uforsigtighed. I de øvrige nordiske lande var praksis langt mere konsekvent. Den nærliggende løsning, afskaffelse af juryen i sager om uagtsomt drab, er først gennemført i 1988. Endvidere gennemgik han Bengt Börjesons betydelige og, nok mest i Sverige, indflydelsesrige værk »Om påföljders verkningar«. Trods megen anerkendelse betvivlede han, om Börjeson havde fået alle nuancer med, f.eks. tog Börjesons inddeling af forbryderne i risikogrupper ikke hensyn til, at af to, der begge havde gjort sig skyldige i tyveri, kunne den ene have et enkeltstående forhold og den anden en serie, hvilket kunne forklare, hvorfor den første fik betinget dom og den anden kom i fængsel.

Klette beskrev den svenske »trafikbrottslighet« og påviste bl.a., at 1/4 af spiritusbilisterne også havde begået andre forbrydelser, og at de fleste overtrædere, modsat hvad mange troede, tilhørte de socialt laveste lag fuldstændig som straffelovsovertræderne; gruppeundervisning var en mindre reaktion end at give synderne en bøde og sende dem tilbage i færdslen. B. Paludan-Müller var mistrøstig over for det danske ungdomsfængsel, som i stedet for Golls »raske Drenge« 
rummede et hårdt klientel, der kun anså tidsubestemtheden som en uretfærdighed og endog forsøgte at forbryde sig ind i en tidsbestemt straf; Paludan-Müller kom tæt på at opgive sanktionen, selvom han ikke sagde det med rene ord. Og så talte Jan Sachs mod den danske praksis, at delvis utilregnelige mordere idømmes livsvarigt fængsel i stedet for forvaring med bedre behandlingsmuligheder.

I 1967 fulgte det sjette nordiske kriminalistmøde i Stockholm, nu desværre uden debatten efter oplæggene, da årbogen var ophørt.

I sit kolossale oplæg »Trafikforseelserne og deres behandling med særligt henblik på motortrafikanterne« gennemgik Theodor Petersen ikke blot nordisk, men fransk, tysk, engelsk og amerikansk praksis. Mange nyttige foranstaltninger, som han omtalte, er senere indgået i dansk ret, f.eks. den islandske regel om, at der dømmes efter den højere promille, hvis alkoholkoncentrationen stiger efter kørslen som følge af indtagelse af alkohol før eller under kørslen. Gunnar Marnell talte i det andet plenaroplæg »Fängelsesamhället« for en omdannelse af fængslet til et terapeutisk samfund, en behandlingsenhed samt for udskiftning af en militariseret omgangsform med generel demokratisering. Hans sociologiske og kritiske syn på fængslerne var typisk for tiden.

Der var seks mindre sektionsemner. Jon Palle Buhl talte veloplagt i »Pornografi« om romanen »Fanny Hill«, der blev frikendt, i hvilken sag han var forsvarer, og anbefalede afkriminalisering af både trykte skrifter (det skete tre dage efter mødet i Stockholm) og billeder (det kom to år senere). Palmgren anbefalede i »Rättshjälpen för anhållna, häktade och fångar« radikale reformer, således at forsvarer ikke beskikkes af retten, men af den lokale advokatforening, som også skal granske forsvarerens salærregning, desuden at det offentlige altid skal udrede udgifterne til forsvarer uanset sagens udfald. Netop dette oplæg har givetvis fremkaldt en livlig debat, som jeg gerne havde set gengivet. De sidste fire oplæg var Rolv Ryssdal: »Korttidsbehandling av unge lovbrytere«, Karl-Erik Törnqvist: »Kriminella alkoholister och deras behandling«, Curt Falkenstam: »Polisreportage«, og Gösta Rylander: »Utillräknelighet«.

Det største andet bidrag i årgang 1967 var Finn Tofte: »Klinisk kriminologi«, der fyldte et helt hæfte på 120 pp. Han krævede ord som straf og fængsel ændrede og straffesystemet ændret til lægelig behandling, profylaktisk og terapeutisk. Den ubestemte tid fandt han i utallige tilfælde direkte ødelæggende på et slidsomt opnået behandlingsresultat. »Enhver lovovertræder har en psykisk baggrund for sin handling, er psykisk afvigende, hvis man nu vil benytte den gængse, noget odiøse talemåde.« Alle burde have tilbud om lægelig behandling, så tidligt og effektivt som muligt. I den meget væsentlige artikel »Konservativ och radikal kriminalpolitik i Norden« betegnede Inkeri Anttila ikke længere den klassiske skole som konservativ og behandlingsideologien som radikal, men slog til lyd for en vidtgående afkriminalisering som virkelig radikal kriminalpolitik, bl.a. af sædelighedsforbrydelser, som mest bæres af hensynet til moralen som f.eks. forbud mod por- 
nografi. Endelig havde Vagn Greve sin første artikel i bladet »Om ungdomsfanger og recidiv«.

Den ældste nordiske kriminalistforening, den norske, fyldte 75 år i 1967 og mindedes af Andenæs $i$ et foredrag, trykt $i$ årgang 1968. Efter lange pauser, senest under krigen, gennemførte man nu møder hvert år. Han betonede den tiltrækkende oplevelse ved studiet af de stenografiske referater, der gav »øket respekt for innsikten, klokskapen og den menneskelige engasjement hos dem som har gått før oss«. Sammen med Bratholm og Christie skrev han en rejseberetning fra Sovjetunionen; de anerkendte, at kriminaliteten var lavere end i Vesten, men strejfede de uhyrlige forbrydelser begåede af de styrende selv, og sluttede, at en højere kriminalitet end i et autoritært samfund kan være en del af prisen for at leve $i$ et frit samfund. Christie skrev også om langhåret livsstil, hvor stofbrug var en væsentlig ingrediens. Han havde »ingen store vansker med å akseptere den totale forbudslinje på det punkt av utviklingen som vi nå befinner oss. Men erfaringene fra alkoholforbudet tilsier at utviklingen må følges med vaktsomme øyne, og forbudslinjen oppgis om omkostningene overstiger en viss margin. « Hauge havde en morsom enquête om, hvor meget man ville betale for at undgå 30 dages frihedsberøvelse, med det uventede resultat, at mange ikke ville betale særlig meget, 30 $\%$ af de adspurgte mindre end $400 \mathrm{kr}$.

Ivar Danvad, Erik Andersen og Aage Kirkegaard skildrede alle 203 anbragte i Sikringsanstalten i Nykøbing Sjælland fra de første patienter i 1918 til dato. $45 \%$ var skizofrene, 29 \% var psykopater; de, der havde begået mord eller forsøg på mord, var fortrinsvis psykopater. Efter anvendelsen af nyere psykofarmaka anbragtes færre i anstalten. Overlæge Mogens Nimb talte om narkobehandling. Han var ikke imponeret af praksis om betingede domme og prøveløsladelser, da genindsættelse for overtrædelse af vilkår var sjælden, men omvendt prioriterede han tvang lavt. Han foreslog forbedret fremme af patienternes motivation, herunder specialafsnit på sygehus, selvom det ville blive dyrt. Fra Sverige skrev Joen Björnberg og Kjell Björnberg om det subjektive rekvisit og de psykisk abnorme; da den syge netop på grund af sin svaghed ikke altid opfyldte kravet om forsæt eller uagtsomhed, burde han ikke erklæres straffri, men frifindes pure og undgå skammen ved en domfældelse; med Voltaire »la honte est dans le crime, et non pas dans le supplice.« Sven Erkkilä skildrede barnemord og fosterfordrivelse efter den seneste finske lov om spørgsmålet.

Tetens gik af og trådte tilbage og afløstes af den nye fængselsdirektor Lars Nordskov Nielsen, ligesom Waaben indtrådte i redaktionen fra årgang 1969. I »Kampen mod straffen « gik Alf Ross til kamp mod de naturvidenskabeligt orienterede eksperter fra den positive kriminologiske skole, der fandt moralsk misbil- 
ligelse og straf som udtryk herfor uforenelig med determinisme, »en vildfarelse der skyldes ufordøjet filosofi«. Han fastholdt tilregnelighedskravet samt med Goos kravet om skyld, ansvar og tilregnelighed som borgerens Magna Charta over for statsmagten. »Psykopatiproblemet fra behandlingssynspunkt« af Stürup lignede et testamente på et tidspunkt, hvor den tidsubestemte forvaring blev angrebet fra alle sider og retssystemet var på vej tilbage til den klassiske skole; han fastholdt den individualiserende behandling som mere humanitært hensigtsmæssig over for de forvarede end standardiseret fængselsbehandling. Han erstattede ordet psykopat med »karakterinsufficient $\ll$.

En ny fængselstype skildredes af fængselsinspektør H.J. Heilbo, der i $»$ Frihedsberøvelse og normaltilværelse« slog til lyd for balancekunst mellem et normalt liv og fængslets krav, herunder de andre justitsmyndigheders forventninger og indsigt. Svend Gram Jensen og Mogens Moe analyserede og kritiserede praksis, hvorved ankeinstansen, når en betinget dom gøres ubetinget, gør straffen kortere, respektive længere, når en ubetinget dom ændres til betinget. Jørgen Verner drøftede sagkyndig psykologisk eller psykiatrisk bistand til dommeren ved afhøring af børn i sædelighedssager; tilværelsen er lettere i vore dage efter indførelsen af afhøring til et videoapparat. Olle Ekstedt beskrev den problematiske svenske lov om »tillrättaförande« af bødedømte ved en kort ubetinget frihedsstraf, når bøden ikke betales. I en sprænglærd artikel »Putativ nöd« kritiserede Nils Jareborg den nye fortolkning af den svenske nødværgeregel, hvorved fejlagtig antagelse af en nøds- eller nødværgesituation ikke udelukker straf, hvis fejltagelsen kan bebrejdes den handlende som uagtsom. Størst risiko for at blive voldsoffer i Oslo var ifølge Brit Bergersen Lind unge spirituspåvirkede mænd fra de lavere klasser boende i Oslo Øst; da årsagen til volden af halvdelen blev betegnet som »fyllekrangel«, kunne mange ofre lige så godt være blevet gerningsmænd selv.

Fra årgang 1970 afgik Hurwitz som hovedredaktør (men blev i redaktionen), efterfulgt af Waaben. Andenæs blev afløst af Christie i den norske redaktion og Jónatan Hallvardsson af professor Jónatan Thormundsson i den islandske. »Är brottsbalken redan omodern? « spurgte Romander, der i 1965 havde hilst den velkommen, sammen med Alvar Nelson og svarede nej, men det ville den blive, hvis man ikke afkriminaliserede især i sædelighedskapitlet, bl.a. søskendeincest, og visse krænkelser af den offentlige orden. I »Butikssnatterier ur kriminalpolitisk synvinkel« fandt K.W. Modigh og Sveri, at det enorme psykiske ubehag for »respektabla« personer, som afsløres første gang, taler for at vente med straf til anden gang, altså ikke afkriminalisering, men »extrem förenkling«. Også de yngste butikstyve skulle behandles mildt, kun politi og børneværn, ikke retten, skulle inddrages. Raimo Lahti gennemgik den nylige finske lovgivning om svanger- 
skabsafbrydelse, sterilisation og kastration. Der indførtes en social indikation for abort, når nedkomst og pasning af barnet ville være »avsevärt betungande« for kvinden; der var i Nylands län opimod 150 legale aborter pr. 1.000 fødsler, syv gange mere end i Lapplands län. Tvangskastration blev afskaffet som en krænkelse af individets retssfære, og frivillig kastration kun tilladt på restriktive vilkår. Paavo Uusitalo sammenlignede recidivet efter løsladelser fra lukkede og åbne fængsler; der var ikke målbare forskelle, men af både økonomiske og sociale grunde var åbne fængsler bedst.

Bratholm gennemgik udkastet til ny norsk straffeprosesslov, bl.a. det evige spørgsmål om juryens afskaffelse, som Bratholm og næsten hele komitéen gik ind for; han citerede formanden Andenæs' svar på spørgsmålet om, hvad han selv ville vælge som tiltalt. »Hvis jeg var skyldig, ville jeg ikke betenke meg på å velge jury. Var jeg uskyldig, ville jeg tenke meg godt om.« Christie modstillede i »Samfunnstilpassing eller ungdomstilpassing « teenagekulturen, som han affærdigede, og ungdommens modkultur, som han stod forstående overfor. Langfeldts påstand i bogen Gåten Vidkun Quisling om, at Quisling burde være mentalundersøgt, hvilket meget muligt havde medført, at han ikke var blevet dødsdømt og henrettet, skabte røre i Norge. Jørgen Smith kritiserede det amerikanske »bail«system, for hårdt mod sigtede i små sager, for mildt mod farlige forbrydere. Moe benyttede den nye regel om votering under navn i Højesteret til at skelne mellem milde og strenge højesteretsdommere uden dog at sætte navn på dem. Karl O. Christiansen konstaterede lavere recidiv for tidligere straffede landssvigere, højere for tidligere ustraffede. Forsvareren Hans Brøchner anbefalede ved den danske forenings årsmøde betinget dom i grupper, som Højesteret holdt udenfor, som arbejdspladstyveri og socialbedrageri, endog spirituskørsel, også for betinget førerretsfrakendelse; i alle tilfælde har senere praksis og lovgivning fulgt ham.

I årgang 1971 afløstes Johannes Halvorsen i den norske redaktion af ekspedisjonssjef Helge Røstad. Ross kritiserede det vidtgående subjektive danske forsøgsbegreb og foreslog straf alene for iværksættelseshandlinger samt - med nedsat takst - forberedelseshandlinger, som efter deres beskaffenhed eller nærmere omstændigheder vækker formodning om at være foretaget $\mathrm{i}$ forbryderisk øjemed. Christie anmeldte med tilslutning et værk af Karen Berntsen om tilbud til stofmisbrugere og foreslog reduktion af tvangsforanstaltninger; den uundgåelige tvang skulle iværksættes af jurister. Endvidere skrev han en stor anmeldelse af nyudgaven af Hurwitz og Karl O. Christiansens Kriminologi, som han roste som håndbog, men ikke lærebog; han savnede et tredje bind om reaktionssystemets kriminologi. Jørgen Littauer og John Kjcergaard påviste, at tildeling af invalidepension til prøveudskrevne fra Herstedvester for mange havde været af væsentlig 
igangsættende betydning for den sociale stabilisering. Birgit Werner fra Mariestad refererede i »Den faktiska brottsligheten« og »Socialgruppsfördelning vid självdeklarerad brottslighet« en stor undersøgelse, hvor over 12.000 værnepligtige anonymt angav sig selv for gængse forbrydelser som tyveri, spirituskørsel m.v. Hele $48 \%$ havde begået butikstyveri, den hyppigste overtrædelse. Kun få var afslørede, hyppigst de, der havde begået mange overtrædelser. Ved den danske forenings årsmøde i 1970 talte forsvareren Arnold Rothenborg om »Særsanktionernes fremtid «. Han anerkendte, at det Stürupske system, »Kampen mod straffen«, havde humaniseret sanktionssystemet, men angreb forvaring af vedholdende små berigelsesforbrydere. Kun de værste aggressionsforbrydere burde kunne holdes forvarede på ubestemt tid. Ungdomsfængslet angreb han særlig stærkt, nok er de unge indstillede på at sone, men vil ikke sidde længere end andre. I 1973 blev de fleste tidsubestemte sanktioner afskaffede, bortset fra forvaring af de allerfarligste.

Nils Beckman døde i januar 1972. Af- og nedkriminalisering var på dagsordenen. Vagn Greve og rigsadvokat Per Lindegaard talte om »Berigelseskriminalitet i velfærdssamfundet « ved den danske forenings årsmåde i 1971. Greve anbefalede vidtgående afkriminaliseringer, bl.a. for undladelse af at betale sin gæld, og en afgift til bestjålne ved butikstyveri snarere end straf. Lindegaard bifaldt visse afkriminaliseringer og hånede særlovgivningens nykriminaliseringer efter princippet nulla lex sine poena, men advarede mod at gøre forretningen kompetent i sager om butikstyveri, da dette kunne medføre afpresning. Han brugte Andenæs' berømte billede om slæbetovet: Retsordenen går foran og slæber den almindelige retsbevidsthed med sig, men afstanden må ikke blive så stor, at slæbetovet brister. Derimod bifaldt han mildnelser, betinget dom i stedet for ubetinget, gerne bøde og i så fald politisag med mulighed for bødeforelæg.

Alvar Nelson gennemgik de mange måder, hvorpå den tidligere pligt for den svenske anklager til altid at rejse tiltale var modificeret ved regler om rapporteftergift, åtalsunderlåtelse og àtalsprövning, og spurgte, om det er lykkeligt at placere magten hos forvaltningsmyndigheder snarere end domstolene. Blandt andre iagttagelser i Jens Feilberg Jørgensen: »Nogle årsagsproblemer indenfor strafferetten « om konkurrerende skadesårsager i sager om uagtsomt manddrab, var, at medens accept af risiko, f.eks. at ofret med viden om tiltaltes beruselse kører med ham, kan udelukke erstatning, består strafansvaret fuldtud. Kauko Aromaa analyserede finsk praksis om strafnedsættelse ved formindsket tilregnelighed og påpegede det paradoksale ved, at straflempelsen kan blive mere end opvejet ved samtidig anvendelse af reglen om skærpelse for recidiv. Viking Modeen orienterede fyldigt om finske straffedomme i 1970-1971. 
Ved det syvende nordiske kriminalistmøde i København i 1973 beskrev Christie i det første plenarforedrag »Strafferett og samfunnsstruktur« dommernes mindskede rolle i samfundet siden 1815; i det snævre samfund udløses konflikter i vold eller retssag, men når staten og socialvæsenet ordner alt, bliver dommeren overflødig, og når han endelig bruges, er det ikke som moralsk dommer om fortiden, men som regulator af fremtiden. Christies løsning var den paradoksale, at dommeren skulle vende tilbage til moralen, men ikke nødvendigvis strengheden. Anttila tog i »Kriminalvård i frihet - social service eller kontroll? « udgangspunktet i, at fængselsvæsenet var dømt til at mislykkes; hun var klar over uundgåelighed af kontrol for de til frivård - hun foretrak betegnelsen »social service« - dømte, men anbefalede, at kontrol og hjælp blev skilt ad, endog at forskellige myndigheder udøvede de to funktioner.

Karen Berntsen nævnte, at 2/3 af alle 14-21 årige i København havde røget hash, og at hun forventede, at alle havde gjort det inden for et par år; hun beskrev Ungdomsklinikkens nedtrapningsarbejde og mente, at efterfølgende anbringelse i provinsen var det hyppigste. Hovrättsassessor Erland Aspelin anbefalede høje bøder, der blev inddrevet med kraft, i stedet for korte frihedsstraffe og mente, at sådanne bøder ville være lige så afskrækkende som en kort frihedsstraf (jfr. under 1968). Hovrättsassessor Jan Freese skrev om »Behandlingen av psykiskt avvikande lagöverträdare«; bl.a. at mentalundersøgelse forudsætter tilståelse eller »övertygande bevisning «, samt at undersøgelse ikke må foretages i bødesager. På mange punkter svarede dansk ret til svensk ret. I kriminalistmødets sidste sektionsoplæg »Skader og tab forvoldt ved kriminelle handlinger « fremlagde Preben Wolf et kolossalt materiale, hvoraf fremgik bl.a., at unge, ugifte, lavt uddannede mænd af arbejderklassen, der boede i storbyerne, særlig i Helsingfors, havde størst risiko for at blive udsat for vold, at langt under $50 \%$ af voldsofrene havde anmeldt overfaldet til politiet, samt at kun få havde søgt erstatning og næsten ingen fået det. Anmeldelsesfrekvensen er utvivlsomt steget i Danmark efter loven om erstatning fra staten til voldsofre i 1976.

Hans Gammeltoft-Hansen drøftede i »De processuelle normers betydning for virkeliggørelsen af den materielle strafferet«, hvorvidt disse regler er fremmende, modvirkende eller indifferente for konstateringen af strafforudsætningerne, især oplysning og vurdering af faktum. Et velkomment bidrag var Jónatan Thormundsson: »Vurdering af tilregnelighed efter islandsk ret«; Island anvender et juridisk-psykologisk kriterium som i Danmark, nemlig om der er kausalitet mellem sindssygdommen og handlingen, så at tiltalte i gerningsøjeblikket ikke var i stand til at styre sine gerninger. Af en studie om voldtægt i Helsingfors 19661970 af Matti Virkkunen, Martti Tenhu og Antti Penttilä fremgik bl.a., at forbrydelsen var i stigning, og at der hyppigere end før var mere end én gerningsmand (41,5\%). Lahti fulgte sin artikel fra 1970 op og mente bl.a. at kunne konstatere, at den friere adgang til abort i Finland havde medført nedgang i tallet på ikkelegale aborter allerede i de første syv måneder efter ikrafttrædelsen af den nye lov.

Heikki Ylikangas resumerede en undersøgelse om vold i historisk perspektiv; fra ca. 1780 var der en eksplosiv stigning, især i Österbotten, skedekniven var 
yndet af enkeltmand, medens banderne anvendte »knoppiskan«; da terror holdt vidnerne tavse, blev næsten ingen dømt. Rolf $B$. Wegner analyserede varetægtsfængsling af unge under 18 i Norge og drøftede muligheden for en alternativ institution. Endelig fortalte Lithner en intrikat historie om den grønlandske eskimo, som i 1926 efter sin dåb tilstod at have skudt den amerikanske geolog Ross Marvin i 1909 på Pearys polarekspedition som intervention i nødværge. Hverken amerikansk, canadisk eller dansk ret kunne ramme drabet, dansk ret fordi Thuleområdet først fik strafferetlige regler i 1929.

Bo Palmgren og Honkasalo døde, og den finske redaktion blev fra årgang 1974 genskabt ved optagelse af Anttila, polisöverinspektör Kyösti Jousimaa og överdirektör for fångvårdsväsenet K.J. Lång. En forsvarer var indleder ved både den svenske og den danske forenings årsmøder. Henning Sjöström havde taget boksehandskerne på. Fængsling kun ved sandsynlighed for ubetinget fængsel i mere end et år; bagatellisering af alle klassiske fængslingsgrunde, især kollusionsarresten; udførlig omtale af en konkret, utvivlsomt af alle genkendt sag, hvor fængslingen kaldtes »tortyr«; krav om politirapportens totale fjernelse fra bevisførelsen, da dommen kun må bygge på det i retten sagte, »icke vad den mistänkta varit utsatt för i häktet«. Jørgen Bang var anderledes ligevægtig og afvejet. Han optog det principielle spørgsmål om anklagerens pligt til objektivitet, som giver ham en fordel over for forsvareren, men er uopfyldeligt for mennesker. Han ønskede en ret for forsvareren til at afhøre »egne« vidner først, men leverede selv hovedargumentet imod, nemlig risikoen for, at han stiller det farlige spørgsmål, hvis besvarelse belaster tiltalte.

Røstad gav en udførlig redegørelse for den norske kriminalstatistik og kriminalitetsudvikling. Mørketallet og den faldende opklaringsrate antydede en endnu større forøgelse i antallet af forbrydelser; blandt tilfældigheder, der kunne farve tallene, var historien om et lensmandsdistrikt, hvor sigtelser for drukkenskabsforseelser i ét år steg fra 0 til meget store tal, fordi en vikarierende bybetjent havde patruljeret i nogle måneder og målt drukkenskaben med byens strengere målestok. Andenæs fangede de nye signaler i kriminalpolitikken, af- og nedkriminalisering, særreaktionernes opgivelse og takstsystemets genoplivelse i forening med humanitet og retfærdighed. Lars Meling: »Individualprevensjonen og juristane sitt kategorimistak«, den første nynorske artikel i NTfK, anbefalede en nyklassicistisk tilbagevenden til moral og etik. Sveri beskrev voldsforbrydelsernes udvikling, hvor særlig gaderøverierne var steget. Christie roste stærkt Ulla Bondesons disputats om fångsamhället, især hendes brug af fangernes kendskab til forbryderargot som tegn på deres prisonisering. Emma Vestergaard (se også 1960) efterundersøgte 12 kvinder, som mange år forinden var udsat for voldtægt eller 
voldtægtsforsøg. For alle var det en chokerende oplevelse, alle havde endnu angstfænomener, flere var svært neurotiserede. Jónatan Thormundsson drøftede skattesvig med delvis sympati for den nye danske regel om optagelse af særlig grove overtrædelser i straffeloven, men anså effektiv kontrol for det bedste modtræk. Peter Sigsgaard havde analyseret alle 67 skadestuebehandlede voldstilfælde over 7 måneder i Godthåb, Grønland, det halve af Frederiksberg, men Godthåb havde ca. 8.000 indbyggere, Frederiksberg ca. 97.000. Mørketallet svarede til Stockholm. Den lille arktiske by havde på disse områder skandinavisk storstadspræg.

Den vigtigste artikel i årgang 1975 var Aspelin: »Utvecklingslinjer i svensk kriminalpolitik efter brottsbalkens införande«; han beskrev afkriminalisering af især overtrædelser af blot moralsk art, »depenalisering« ved udskiftning af bødestraf med en afgift, udvidelse af muligheden for åtalseftergift og rapporteftergift, processuelle forenklinger, delvis erstatning af frihedsstraffe med bøder og betingede domme, men også skærpelse af visse voldsforbrydelser, skatte- og milieuforbrydelser, endelig oprettelsen af brottsförebyggande rådet, BRÅ. Bertil Werner skildrede den svenske debat om udviklingen fra absolut til relativ åtalsplikt, hvor det sidste skridt ikke var taget. Leif G.W. Persson argumenterede i »Tillfället gör tjuven« for en »tillfällesstruktur« af kriminologien, d.v.s. at tyven stjæler, som tilfældet byder sig; er der mange automobiler, begås mange tyverier af automobiler etc.; han krævede til sidst retfærdige og lige sociale præmisser for de forskellige individer som den bedste forebyggelse af kriminalitet.

Aromaa beskrev en »våldsgallup« i 1970 og atter 1973 som offerundersøgelse; yngre »intellektuelt arbejdende « mænd syntes at være mere udsat for vold end før, hvilket ikke svarer til de gængse iagttagelser. Hauge og Harald Stabell analyserede politivirksomheden i Follo (syd for Oslo); medens den udgående patrulje var koncentreret om lovovertrædelser, vedrørte $41 \%$ af publikums henvendelser assistance, d.v.s. at politiet blev betragtet som et generelt serviceorgan; mon dette stadig gælder i dag? Gram Jensen beskrev den ekstraordinære nedsættelsesregel i straffelovens $\S 85$ og efterlyste en nedsættelse af de høje minima særlig for manddrab. Lise Koch påviste, at der under straffefangers udgang som f.eks. orlov hver tredje week-end i praksis sjældent var misbrug, og at udgang snarere burde tildeles endnu mere liberalt henset til dens gavnlige virkninger. William Rentzmann beskrev de mulige alternativer til de skadelige frihedsstraffe, week-end fængsel, fremmøde hos politi som ren kontrol og særlig samfundstjeneste, som han ventede sig mest af. Den senere udvikling har i høj grad fulgt ham. Thórdur Eyjólfsson døde. 
Karl O. Christiansen døde og mindedes varmt af Waaben. Årgang 1976 bragte hans sidste artikler om urbaniseringens betydning for kriminaliteten og om udviklingen i Japan, hvor kriminaliteten var mindsket hvert år siden krigen, muligt på grund af samhørighedsfølelsen mellem befolkningen og det lokale politi. $\mathrm{Nu}$ kom for første gang en islandsk kronik. Lars-Göran Engström forelagde i den svenske forening et forslag om sexuella övergrepp - »sedlighet« og »(o)tukt« hørte ikke hjemme i en moderne lov - med vidtgående lempelser, nedsættelse af den kønslige lavalder til 14 år, afkriminalisering for incest, dog med en aldersgrænse på 18 år i den nedstigende linje, og henvisning til den voldtagne kvindes adfærd som formildende omstændighed. De næste to årganges svenske krönika refererede de kraftige protester mod forslaget, og i den sidste ende gennemførtes kun nedsættelsen af den homoseksuelle lavalder til 15 år. Anttila ønskede alle særregler for unge forbrydere afskaffet bortset fra en generel regel om mildhed over for en tiltalt under 18 år, som kun i undtagelsestilfælde kunne idømmes fængsel; for første gang så jeg en ekspertkomité omtalt, som bevilgede midler til oversættelse fra finsk til svensk.

Kåre Bødal skildrede fængselsvæsenet i Norge, både institutioner, bygninger - Botsfengslet var nedlagt som landsfængsel og Møllergaten nedrevet - og klientel. Justitsminister Inger Louise Valle fra Arbeiderpartiet ville ikke bagatellisere tyveri, den lille mands nye bil eller flotte plastbåd fortjente beskyttelse, men hun påtalte, at nykriminaliseringer som milieu- og skatteovertrædelser straffedes mildt som forseelser, hvor gamle overtrædelser som især tyveri straffedes strengt som forbrydelser; hun ønskede frihedsstraf erstattet med andre sanktioner, f.eks. samfundstjeneste, som nu havde nået Norge. Ole Ingstrup omtalte en dansk udvalgsbetænkning, hvor flertallet foreslog reglerne om genindsættelse af prøveløsladte eller fuldbyrdelse af betinget dom for vilkårsovertrædelse afskaffet, bortset fra ny kriminalitet; mindretallet, bl.a. Lindegaard, var kraftigt imod, og reglerne er ikke blevet ændret. Beth Grothe Nielsen kritiserede dansk praksis, hvorefter der straffedes for underslæb selv uden et lidt tab, blot der var påført ofret risiko for tab.

Endvidere omfattede årgang 1976 hovedindlæg og diskussion fra et nordisk symposium i Sverige, efter at Sverige og Finland havde afskaffet de udtrykkelige regler om strafskærpelse ved recidiv, återfall. Der var stort set enighed om, at der stadig ville blive taget hensyn til återfall, men i mindre grad end før (Dag Victor). Vagn Greve fastslog, at ved ligestilling af førstegangsforbrydelse med recidiv ville argumentet for en mild behandling af debutanter forsvinde; konsekvensen ville ikke blive en mild behandling anden gang, men en hård behandling første gang. 
Det vægtigste, stadig læsværdige bidrag i årgang 1977 var Andenæs' gennemgang af nyere amerikansk forskning om almenpræventionen. Udgangspunktet var behandlingstankens fallit, valget stod ikke imellem almen- og specialprævention, men mellem almenprævention og ingen reaktion. Samtidig inddrog han socialøkonomernes indmarch $\mathrm{i}$ forskningsfeltet med slagordet: »To reduce the frequency of crime, economists generally recommend we raise the cost of crime." Anerkendelsen af lovens legitimitet hos de berørte befolkningsgrupper var også af stor betydning. Hauge påviste fra særlig engelske undersøgelser - som de fleste andre kriminalister omtaler Hauge kun angelsaksisk eller nordisk litteratur, men aldrig kontinentaleuropæisk - at politiet opfatter almenhedens opfattelse af politiet som langt mere negativ, end den i virkeligheden er, og at dette kan påvirke politiets adfærd over for især unge mænd, ofte af minoritetsgrupper, på uheldig måde.

Waaben talte for bevarelse af prøveløsladelsesinstituttet ud fra et ønske om at reducere straffens længde, særlig ved de lange domme, »som jo er lette at idømme men svære at fuldbyrde og at udstå«, en fin formulering. Desuden kan prøveløsladelse slå bro over spændingsforholdet mellem den »rigtige« dom på domstidspunktet og den straf, man vil fastholde, når den første indignation har lagt sig. Agnete Weis Bentzon skildrede grønlandsk retspraksis i sager om voldtægt og husherrens vold mod hustru og andre kvindelige familiemedlemmer og påviste den betydelige forskel mellem synet på disse forbrydelser hos de danske anklagere og de meget milde grønlandske dommere.

Desuden omfattede årgangen hovedindlæg og diskussion fra et finsk-svensk symposium i Åbo »om modern strafflagsstiftning«. Jareborg analyserede den strafbare uagtsomhed og påviste, at culpa fremtræder enten som gerningsculpa, hvor selve handlingen er retsstridig, eller personlig culpa, hvor en retmæssig handling udføres på uforsvarlig måde. Pekka Koskinen beskrev, hvordan den finske straffrättskommitté ændrede den tidligere lovs effektansvar til et fareansvar, men tilføjede, at man for ikke at skulle rejse alt for mange sager for uagtsom farefremkaldelse muligt kunne anvende effekten som selektionskriterium og kun rejse de sager, hvor faren var udløst i en ulykkelig følge. P.O. Träskman opstillede et ambitiøst program om juridiske personers strafansvar, »Det är svårt att motivera att småtjuvar bestraffas om ingen straff följer för att fabriken smutsar ner land och sjö, « medens Asko Lehtonen påviste det begrænsede ansvar i gældende ret. Patrik Törnudd og Lauri Lehtimaja kommenterede det endnu halvfærdige finske straffelovsforslag.

Brottsförebyggande rådets betænkning Nytt straffsystem, som indvarslede nyklassicismen i svensk og nordisk kriminalpolitik, blev i årgang 1978 angrebet kraftigt af Ulla Bondeson i »Vad är nytt i Nytt straffsystem?« Hun bestred, at indivi- 
dualpræventionen var modbevist, og hævdede sin egen teori om negativ individualprævention, jo mere indgriben, des skadeligere virkninger. Hun frygtede for, at den nye teori om proportionalitet med tillæg af återfallets betydning ikke ville føre til mildere straf, men i hænderne på konservative til en reaktionær udvikling. An-Magritt Jensen gennemgik 63 kvinder dømt ved Oslo byrett i 1977. De fleste tilhørte de laveste lag, men der var ikke megen forskel til dømte mænd, bortset fra, at kvinderne udviste mindre dristighed og hyppigere blev dømt for simple end grove tyverier. Ifølge Oslolægen Ottar Tangen mishandles børn oftest af den biologiske moder, som omvendt nyder stor yndest hos myndighederne; værst en sag, hvor børneværnet havde fjernet en mishandlet spæd pige hos en plejefamilie, men hvor en dommer 2 år senere gav moderen barnet tilbage; $2 \frac{1}{2}$ måned senere blev barnet mishandlet til døde.

Ross analyserede uagtsomhed, som han i lighed med den nyeste teori gav både en objektiv og subjektiv side. Han hævdede, at overtrædelse af udtrykkelige forskrifter kun har vejledende betydning, og at det afgørende kriterium er domstolenes selvstændige, skønsmæssige vurdering, hvis praktiske udformning han roste. I stedet for betegnelsen »bevidst uagtsomhed« foretrak han »hensynsløshed«, engelsk »recklessness«. Flemming Balvig forbandt Christiania med den kortvarige nedgang i kriminaliteten i midten af 1970'erne og betonede den positive nedkriminalisering, der selv efter en overtrædelse bragte gerningsmanden ud af kriminaliteten, f.eks. hjalp man en christianit, der i en kuldeperiode begik indbrud og stjal en ovn, til at få en ovn på billige vilkår; Balvig udtrykte det ved, at tyven blev sparket opad i stedet for nedad. Professor Stanley Anderson fra Santa Barbara roste i »Ombudsmen and Prisons in Scandinavia« ombudsmandsinstitutionens undersøgelser af forhold og klager i fængslerne og konkluderede »In a word, Ombudsmen foster fairness within prisons. « For Danmark roste han fængslerne som endnu mere »progressive« end i Sverige, især Herstedvester, hvorimod han kaldte danske arresthuse »disgraceful« som i det meste af resten af verden. Han beklagede, at domstolene ikke var undergivet ombudsmanden i Danmark og andre lande, der havde den danske ombudsmand som forbillede, modsat Sverige og Finland.

\section{1979-2012}

Medens tidsskriftet i 1948-1949 fik en mægtig styrkelse, hvilket gav sig udslag i fyldigere format, nye rubrikker etc., var krisen i 1979-1981 langt alvorligere, endog livstruende. Igennem mange år var der opstået stadig større forsinkelser. For at holde forsinkelserne stangen kom redaktionen ind på at udsende dobbelthefter, kun i ét år i 1960'erne og 1970'erne blev der udsendt fire separate numre. 
Også indholdsmæssigt var der problemer. Da årbogen nedlagdes efter 1962, aftalte man, at alle årsmødeforedrag skulle trykkes tillige med den følgende debats hovedpunkter, men i praksis kom kun de danske foredrag nogenlunde regelmæssigt, debatten aldrig. Endelig var det smukke, ja elegante format langt dyrere end kontingentet kunne klare. Det blev ikke bedre ved, at Kandrups bogtrykkeri udover det fornemme arbejde havde udvist betydelig kulance ved at lade gælden vokse, et beløb der naturligvis måtte udredes, hvis man ville overgå til et billigere trykkeri.

Heldigvis var der ved to krisemøder i 1979, det ene i Oslo ved det ottende nordiske kriminalistmøde, enighed om at redde tidsskriftet. Forsinkelserne gjorde man kort proces med ved, at den næste årgang kaldtes »1979-1980«, også årgang 1981 blev meget tynd, to hefter. Den store redaktion afløstes af en ordning med kun én redaktør og muligt en redaktionssekretær pr. land. Fra Danmark, Norge og Island fortsatte Waaben, Christie og Thormundsson, fra Finland indtrådte Träskman og fra Sverige Jareborg. Christie var også formand for Nordisk Samarbejdsråd for Kriminologi, der på denne måde viste sin vilje til samarbejde med NTfK.

I 1981 afløstes Waaben som hovedredaktør af Greve og fortsatte alene som dansk kronikør. Greve sanerede økonomien. Som foreningsblad kunne NTfK opnå momsfritagelse, hvilket krævede mindst 4 numre pr. år, ingen abonnenter udover medlemmerne og ingen annoncer. Greve fjernede de sidste to annoncer, »tvangsindmeldte « de sidste ikke-medlemmer - enkelte forsvandt - bragte medlemstal og abonnenter op fra ca. 330 til ca. 600 og udsendte 4 eller 5 numre pr. år, og endelig, smerteligst, opgav han den fornemme høje skikkelse og brune omslag og gik over til et mindre format på billigere papir. Kandrups bogtrykkeri, der fortsat anvendtes, fik sit tilgodehavende betalt. I 1982 udtalte den danske forenings bestyrelse varm anerkendelse til Greve for, hvad der uden overdrivelse kan karakteriseres som tidsskriftets redning.

Nyklassicismen, det vigtigste plenaremne i kriminalistmødet 1979, blev angrebet af Christie, der fastholdt behandlingstankens omsorg, lindring, pleje og godhed. Specialpræventionen i positiv forstand var svækket, men ikke negativt jfr. Ulla Bondeson. I stedet for »datamaskineløsningen « ville han civilisere konflikterne bl.a. ved konfrontation mellem gerningsmand og offer. Törnudd fastholdt som korreferent nyklassicismen og fremhævede dens retssikkerhed, bl.a. ved at skærpende omstændigheder skal konkretiseres i loven, medens en friere bedømmelse er tilladt for formildende omstændigheder. Christies løsning kunne lige så vel medføre uacceptabel strenghed som mildhed.

I sektionsmødet »Modern ekonomisk brottslighet« kritiserede Sten Heckscher de lave straffe for moderne forbrydelser og konkluderede, at disse virkede som olie i samfundsøkonomien, og vil man af med dem, forudsætter det dybtgående forandringer i samfundet, som ligger uden for 
et nordisk kriminalistmødes rækkevidde. Der var to norske indledere om emnet $»$ Rettssikkerhet og rettslig kontroll under fullbyrdelse av frihetsberøvende sanksjoner«; journalist Gerd Benneche krævede lighed og forudsigelighed samt fuld aktindsigt for den indsatte og nærmest forkastede skønnet, medens byråsjef Arild Kjerschow så historisk på problemet og understregede, at mange forbedringer var begyndt som individuelle begunstigelser og aldrig kunne være gennemført på én gang ved lov.

Tove Stang Dahl påviste, at Christies og Goldschmidts »ikke-intervention« og aktive tolerance mod gerningsmanden kun er gyldig over for stærke ofre som forsikringsselskaber, men ikke for svage ofre, særlig kvinder som ofre for vold fra ægtemand eller samlever. Ingstrup anbefalede læge kontaktmænd m.v. både af økonomiske og ideologiske grunde og langede ud efter nyklassicismen, »unuanceret og sjusket ... ophøjet filosofisk selvglæde«. Endelig sammenlignede Uusitalo i plenaremnet »Samhällsplanering och kriminalitet« den lave kriminalitet i Tammerfors med patriarkalske arbejdsgivere og stærk arbejderbevægelse og det mindre sammenhængende Lahtis, medens Balvig hævdede, at kun en radikal omfordelings- og udjævningspolitik ville afhjælpe den lille restgruppes massive kriminalitet.

Blandt andre bidrag til årgang 1979-1980 var indledningerne til den danske forenings årsmøde i 1979 om isolation af varetægtsfængslede, der blev angrebet af landsdommer Ole Unmack Larsen, overlæge Finn Jørgensen og advokat Henrik Viltoft og forsvaret af fængselsinspektør Jørgen Heilbo med nuanceret beskrivelse af den isoleredes dagligdag. »Polisen och bostadsinbrott« af Johannes Knutsson analyserede den faldende opklaringsrate, fra ca. $14 \%$ til ca. $6 \%$ på 10 år; tilsyneladende anholdtes og afsløredes lige så mange som før, men der var ikke tid til at efterforske flere forhold end dem, der opklaredes af sig selv. Landsdommer Henning Brøndsted beskrev det grønlandske retsvæsen, særlig de læge kredsdommere, på grund af en bog af Agnete Weis Bentzon og gav et smukt billede af et forenklet, men fungerende system. En mand fra Østgrønland, der i beruselse havde skudt sin hustru, blev idømt tilsyn og afvænning for spiritusmisbrug, da anstaltsanbringelse i Vestgrønland ville gøre det vanskeligt for ham at vende tilbage til en normal tilværelse; landsretten stadfæstede. Lithner: »Tillämpning av opportunitetsprincipen vid åtal i USA« analyserede et ved første øjekast meget lidt betryggende system, som dog ved nærmere indblik var rationelt; især tvang den overvættes arbejdsbyrde til slutning af sager i voldsomt omfang.

Hurwitz døde i 1981 og blev mindet af Andenæs. I denne årgang kom man vidt omkring. Andenæs havde været i Kina; han anerkendte bestræbelserne på at (gen)skabe et retssamfund efter kulturrevolutionens rædsler, men betvivlede muligheden herfor i et samfund, hvor al magt var samlet på samme hænder; nok forbød straffeloven tilbagevirkende kraft, men da magthaverne alligevel havde magt til at definere kontrarevolutionær virksomhed, var dette forbud ikke meget værd. Gisli H. Gudjonsson og Hannes Petursson beskrev drabsforbrydelsen i Island, 
næsten intet før 1940, men stor stigning i den nye republik; kun tre kvinder var dømt for drab, men 18 af 34 ofre var kvinder; Hæstarettur anerkendte formildende omstændigheder i en sag, hvor en mand i ustyrligt raseri havde dræbt sin hustru, der under et ægteskabeligt samleje var blevet ved med at kalde ham ved et forkert navn. Elina Helander beskrev samernes ældre ret; rentyverier var en hyppig forbrydelse; stjal man af sult, blev man straffet mildere end hvis man havde solgt det stjålne, og tyveri fra en fremmed stamme tog man ikke alvorligt.

Mere hjemligt gennemgik Gorm Toftegaard Nielsen og Sven Ziegler straffesager efter særlovgivningen og var enige om, at anklagemyndigheden skulle foretage en selvstændig vurdering og ikke blot være særmyndighedens »forlængede arm«. Persson kortlagde prostitutionen i Sverige; ca. 2.000 prostituerede, ca. 100.000 kunder, nogle hundrede »hallickar«; han anviste flere måder at bekæmpe prostitutionen på, men afviste kriminalisering af de prostituerede og/eller deres kunder. »Kriminaliseringar som inte kan kontrolleras effektivt är enbart av ondo.«

Den danske forenings formand, rigsadvokat Lindegaard, skrev den første artikel i årgang 1982, den første i det nye format, en grundig gennemgang af alle trykte domme 1973-1980, hvor spørgsmålet om betinget dom spillede en rolle; praksis var mildnet særlig for arbejdspladstyveri og socialbedrageri. Vægtigst $\mathrm{i}$ denne årgang var Andrew von Hirsch: »Nyklassicism, proportionalitet och straffets grunner«, et præcist forsvar for nyklassicismen. Almenpræventionen begrundede kun, at der blev straffet, men ikke hvor meget, og moralvirkningen fandt han ubevist. Derimod udtrykte proportionalitet, »just desert«, præcist graden af »klander« over for forbryderen, nøjagtig som karakterens størrelse viste, hvor meget eller lidt eksamenskandidaten havde fortjent.

Madeleine Löfmarck gav en stofmættet gennemgang af den omfattende lovgivning mod skattesvig, skyldnersvig, hæleri m.v. og efterlyste enklere og bedre kontrollerbare foranstaltninger af hensyn til både effektiviteten og retssikkerheden. Leif Petter Olaussens referat af norske offerundersøgelser i 1971, 1974 og 1981 viste en flerdobling af opgivne legemskrænkelser og trusler i 1981 end tidligere, hvad enten det skyldtes en sænket tolerancetærskel eller en reel opgang. Unge, enlige i Oslo med mellem- eller høj indkomst var langt mere udsat for vold m.v. end ældre, gifte, der boede på landet. Lise Koch drøftede »Retspolitiske problemer vedrørende indsattes rettigheder under straffuldbyrdelse«; under henvisning til det betænkelige ved, at kriminalforsorgen både fastsætter reglerne, forvalter dem og sanktionerer brud på dem, foreslog hun en fængselslov (gennemført 2001). Årgangen bestod af 5 små hæfter til tiden, ikke flere forsinkede dobbelthæfter. 
I årgang 1983 opregnede Teuvo Peltoniemi de forskellige teorigrupper for familievold - psykopatologiske, familiedynamiske, kulturelle, samfundsstrukturelle - og spurgte, om familievold adskilte sig fra anden vold, og hvor længe ville det være et modeforskningsområde? I »Vad är ära? « kontrasterede Tuija Mäkinen sager om ærekrænkelse i 1919/1920 og 1978, fortrinsvis i Helsingfors. Antallet af sager var faldet fra 996 anklagede pr. million indbyggere i 1900 til kun 23 i 1979, især var beskyldninger for forbrydelse eller økonomisk uredelighed gået tilbage; at kalde en kvinde »hora« var stadig en yndet injurie. Jukka Kekkonen og Heikki Ylikangas forbandt frihedsstraffens historiske gennembrud med den almene kontrolpolitik, som strafferetten er en del af, og forklarede den tidlige enevældes forkærlighed for kropsstraffe modsat den oplyste enevældes mildhed med, hvilke samfundsklasser regimet støttede sig på.

BRÅ's överdirektör Bo Svensson foreslog, at hvert forslag om strafskærpelse skulle ledsages af et forslag om modsvarende lempelser, så nettoresultatet blev uændret fangetal. Det gode ved bøden var, at den ikke kunne forklædes som en fordel for den dømte. Landsdommer $H$. Kallehauge analyserede narkotikasager ud fra retssikkerhedssynspunkter; de gængse gode beviser manglede, og dommene måtte afsiges med støtte i indicier; det var en heksekedel, som ikke måtte blive til hekseprocesser. Jan Petersen gennemgik de første 6 års sager, 44 i alt, fra statsadvokaten for alvorlig økonomisk kriminalitet, der viste den nye myndigheds berettigelse, og Lindegaard beskrev danske domme, især Glistrupsagen om en advokats skattesvig i kolossalt format, fra 1980-1983; forrige gang NTfK havde disse nyttige oversigter, var i 1972. Der var en kronik fra Europarådet (Erik Harremoes). Mere end før var der mange, lange og oplysende boganmeldelser, hele artikler.

Jareborg udtrådte af redaktionen, afløst af Heckscher. Årgang 1984 svulmede op til 502 pp., deraf 184 pp. indlæg til det niende nordiske kriminalistmøde i Helsingfors.

Hovedemnet var »Kriminalitetsudviklingen 1950-92«, Balvig referent og Bo Svensson, Sturla Falck, Törnudd og Timo Aho korreferenter. Alt var med, i Danmark stagnerende kriminalitet i lavvækstsamfundet 1950-1958 og stigende kriminalitet i højvækstsamfundet derefter, den synkende moral særlig ved tyverier over for ukendte, den lille restgruppe, der begik de mange forbrydelser, stofmisbrugets udvikling fra modefænomen til socialt problem, »overklassens luner blev underklassens laster«, de tilsvarende stigninger i de andre lande, men også de særlige finske forhold med højere opklaringsprocent og strengere straffe, som dog i de senere år var kraftigt mildnede, bl.a. ved afkriminalisering af fylleri og afskaffelse af tugthusstraffen.

Hans Holmér omtalte bl.a. telefon- og rumaflytninger, overskudsinformation og provokation. Fængselspsykiateren Matti Tuovinen skrev i »Ett fängelse i fängelset« om skadevirkningerne 
ved isolation under afsoningen. Sysette Vinding Kruse drøftede strafansvar for juridiske personer, gængs i Danmark, næsten ukendt i de andre lande. R.N. Torgersen, »Reaksjonene ved promillekjøring « noterede umuligheden af ensartede regler i de nordiske lande; det var ikke god tone at foreslå bøde i stedet for frihedsstraf af samfundsøkonomiske hensyn. Heckscher, »Samhällstjänst«, afspejlede den fortsatte svenske modvilje mod sanktionen på grund af risikoen for glidning ved anvendelse på andre end dem, der ellers ville blive dømt til fængsel, og social skævhed i udvælgelsen. Håkon Lorentzen skrev om vold fra og mod politiet og pegede på en ny arbejdskultur i politiet med vægt på effektiv og hurtig »oprydning«. Träskman, »Den allmänna opinionen, massmedia och rättssäkerheten«, havde mange udfald imod den finske presse; han frygtede pressens tendens til at reducere kriminalitetens problem til enkeltsager, værst et dobbeltmord begået af en fange på orlov.

I samme årgang påviste Tavs Folmer Andersen og Balvig, at af unge fra et slumområde i København blev $37 \%$ strafferegistreret mod kun $16 \%$ af unge fra et bedre boligkvarter (Emdrup), og at forskellen steg ved inddragelse af forsørgerens erhverv og boligstandarden. Det forsinkede svenske lovforslag om sexualbrott var renset for de mest omstridte ingredienser i udkastet fra 1976 (Anita Meyerson). Risto Jaakkola satte Verkkos moralstatistik ind i finsk og europæisk historisk sammenhæng. Andenæs' omtale af norske domme 1982-1983 omfattede demonstrationerne ved kraftværket ved Alta, hvori deltog professorerne Christie og Mathiesen, de store bøder, som Høyesterett godkendte, og det intrikate problem om konfiskation af de ski og skistave, som de dømte brugte for at komme ind på det forbudte område, og som tilhørte »Folkeaksjonen «, som anklagemyndigheden forsømte at inddrage i sagen. Røstad analyserede sædelighedsforbrydelser i 1982 og 1983; voldtægt var i stigning, og flertallet af voldtægtsforbrydere var tidligere straffede, ofte massivt; han havde næsten medfølelse med blotteren, der gentog sin overtrædelse hver uge og ofte kom blåfrossen og gennemvåd hjem - )i et så barskt land som vårt vinterstid [er det] ikke ... så lett å utfolde seg fullt ut på et gebet som dette«. Per Ole Johansen udforskede kontrollørerne ved hjemløseherberger i Oslo og fik bekræftet sin hypotese om, at de ansatte ved det største herberg, hvor de praktiske problemer, især med drikkeri og forsøg på at indsmugle alkohol var størst, havde mere autoritære holdninger end de ansatte på mindre og afsides beliggende herberger.

Årgang 1985 stod i Nordatlantens tegn. »Kriminalitetstendenser i Island« af Hildigunnur Ólafsdóttir burde have været med ved kriminalistmødet i 1984. Tendenserne lignede de øvrige nordiske lande, en lang årrække med stigende kriminalitet efterfulgt af stagnation; der var større tolerance over for økonomisk kriminalitet end over for traditionel kriminalitet, synspunktet er unægtelig blevet ændret siden da. Lægerne Inge Lynge og Anne Køster skildrede de grønlandske 
bestemmelser om psykisk abnorme og mentalobservationer, af hvilke de mest belastende foretoges i Danmark, ofte fulgt af anbringelse i Herstedvester. En grønlandsk kronik af Elisceus Kreutzmann resumerede de stadig forgæves bestræbelser på afsoning i Grønland også af de tungeste dømte, uløst endnu i dag; Grønlands eget kriminalforsorgsnævn afslog ansøgninger om overførsel til afsoning $\mathrm{i}$ Grønland. Landsdommer C.K. Kjorsgaard analyserede de intrikate rettighedsfrakendelser i interprovinsielretlig belysning, især spørgsmålet om førerretskendelsers territoriale virkning mellem Danmark og Færøerne; hans løsning, at frakendelse kun har umiddelbar virkning i den rigsdel, hvor den er bestemt, og at udvidelse til den anden rigsdel skal løses særskilt, gerne samtidig, synes rigtig.

Uden for Nordatlanten redegjorde Bratholm og Träskman for det langsomme slid med reformen af de norske og finske straffelove. Bratholm havde en fin kommentar til den foreslåede afskaffelse af overførslen af sager mod unge til børneværnet; »Påtalemyndigheten overlater saken til barnevernsnemnda og barnevernsnemnda overlater lovbryteren til seg selv.« Henning Koch fortalte om sin deltagende observation med det aarhusianske ordenspoliti og om den store fremgang i ordenspolitiets effektivitet efter politikredsreformen af 1973, der syntes at have truffet det rette. Balvig påviste, at danskerne ikke - som populært antaget var verdens mest tyvagtige folkefærd, det syntes bare så, fordi mørketallet var langt mindre end f.eks. i Finland og U.S.A. Selv i Zürich i det fredelige Schweiz var risikoen for at blive udsat for tyveri større end i Danmark! Afdelingsleder Lotte Skovgaard, kriminalforsorgen i min by Hillerød, fortalte om sit arbejde, helt ned til de små, men vitale bevillinger fra hjælpekassen som ophold til en elsket hund på hundepension.

Den store begivenhed, der prægede årgang 1986, var den svenske forenings 75 års-jubilæum, som fejredes med fire vægtige artikler over den meste af et hæfte efter Magnus Sjöbergs indledning. Alvar Nelson, »Svenska kriminalistföreningen 1911-1986 i ett nordiskt perspektiv«, trak de store linier op, nævnte de store, ikke blot i Sverige, især Schlyter, for hvem det stærke samfund var bygget på »ansvarstagande, icke maktbegär«, en fin formulering. Indbyrdes påvirkning blev fremdraget, således Dansk kriminologisk Selskab som inspiration for Kriminalpolitiska Sällskapet. Aspelin var trofast tilhænger af justitsminister Lennart Geijers radikale afkriminaliseringsønsker, men advarede mod »depenalisering «, afgifter i stedet for straf, dels af retssikkerhedshensyn, dels af hensyn til social lighed. Marianne Håkansson: »Tretton år med kriminalvårdsreformen«, skitserede den senere udvikling, bl.a. i retning af udvidet brug af villkorlig dom, frigang og permission, hvor misbrugsraten var radikalt faldet. Bo Svensson ønskede maksimal tilbageholdenhed med at regulere erhvervslivet ved hjælp af straf og foretrak 
administrative afgifter og andre sanktioner. Blandt andre svenske bidrag var Madeleine Löfmarck: »Nyklassicismen - vart tog den vägen?«, der bestred både, at behandlingstanken havde rådet uindskrænket inden nyklassicismen, og at denne senere havde udkonkurreret den. »Den avfärdade behandlingsideologin har efterträtts av - ingenting. « En betænkning fra Fængselsstrafkomitéen blev gennemgået af formanden, Carl-Johan Cosmo, der ønskede klare anvisninger i loven for at sikre lighed og forudseelighed.

Uden for Sverige var det vigtigste en studie af Trude B. Nergård og Olav Molven: »Nordmenns holdning til vinningskriminalitet«, der på grundlag af 1.040 interviews påviste, at en stærk religiøs holdning øger en restriktiv holdning til formueforbrydelser, især hos de unge. Willem de Haan (oversat til dansk) fortalte om store udvidelser i det nederlandske fængselssystem, hvilket ikke stemte med den gængse opfattelse af Nederlandene som landet med det laveste fangetal i Vesten. Lars Nordskov Nielsen analyserede det vanskelige forhold mellem tavshedspligt og oplysningspligt i kriminalforsorgen; hvor meget må kriminalforsorgen fortælle andre myndigheder om fangernes forhold? Ulla Høg fortalte om EFkriminalitet, det var første gang; jeg var anklager i en af de sager, hun beretter om (om tomater), den gik delvis i stykker på grund af forældelse.

Årgangens sidste hæfte var tilegnet Inkeri Anttila til 70 års dagen, 18 bidrag fra alle fem lande dækkende tidens kriminalpolitiske spørgsmål, men også hyldende fødselaren, således Røstad, der fremdrog hendes arbejde i det internationale kriminalistmilieu, herunder som direktør af HEUNI, Helsinki Institute affiliated with the United Nations.

I årgang 1987 fastholdt von Hirsch og Jareborg i polemik med Madeleine Löfmarck proportionalitet mellem forbrydelse og straf som det grundlæggende princip for strafudmåling, også af etiske grunde; straf indebærer dadel, som bør gradueres efter udvist skyld; ordet »nyklassicisme« brød de sig ikke om. »Slag i luften mot brottsligheten « af Alvar Nelson gennemgik og kritiserede de mange sanktionsafgifter indført især af Olof Palmes anden regering; retssikkerheden var krænket, og de få, som ramtes, oplevede indgrebet som en uretfærdighed. Per Ole Johansen skildrede i »Kampen om den tvungne voldgift 1927-1929« den store konflikt, herunder den sejrrige civile ulydighed, som endte med total amnesti over for nærmest sabotage mod loven; når der er tilstrækkelig mange bevidste lovbrydere, er loven umulig at håndhæve. Historisk var også Bertil Frosell: »Tugt og dadel« om Goos' strafferetlige tænkning; det er ikke umuligt, at Goos fik mere indflydelse på den danske straffelov af 1930, end også jeg har været tilbøjelig til at tro. 
I deres gennemgang af norske domme 1984-1985 omtalte Svein Slettan og Toril M. Øie bl.a. den kritisable dom Rt. 1984,1146, hvor Høyesterett ved strafudmålingen i en sag, hvor tre tyrkiske indvandrere dræbte en landsmand, som havde haft seksuel omgang med en 18-årig kvinde, der var henholdsvis datter og søster af drabsmændene, tog hensyn til skikken i de domfældtes hjemland. Bibliotekar Halvor Kongshavn gennemgik i »Hasj på apotek « avisernes omtale af Christies og Ketil Bruuns bog »Den gode fiende«; nok tog pressen udgangspunkt i bogens anbefaling af, at cannabis blev tilgængeligt for indkøb på apotek, men de rigtige anmeldere havde fanget budskabet. Peter Kramp m.fl. havde undersøgt 27 unge 15-17 årige, der havde begået alvorlig kriminalitet, heraf 9 drab, drabsforsøg eller vold med døden til følge. Trods retspsykiaterens og Retslægerådets anbefaling i alle sager af psykiatrisk behandling eller inddragelse under bistandsloven var 10 idømt almindelig fængselsstraf; flere var grænsepsykotiske; Kramp foreslog en lukket psykiatrisk afdeling for at undgå den ofte katastrofale fængselsstraf. Endelig var der ca. 80 (af 422) pp. boganmeldelser af hele 53 værker, en fin udvikling (1987 var mit eget første år som anmelder i NTfK).

Heckscher afløstes fra årgang 1988 som svensk redaktør af Bo Svensson. Årgangen var mest norsk, herunder anmeldelsen af Andenæs: Et liv blant paragrafer (v/Lindegaard) blandt de 61 boganmeldelser. I gensvar til von Hirsch og Jareborg fastholdt Andenæs både almen- og individualpræventionens berettigelse ved siden af proportionalitet, som ikke kunne stå alene; han anerkendte, at behandlingssynspunkter ikke kunne begrunde en strengere udmåling, men i sjældne tilfælde en mildere, f.eks. for at afbryde en kriminel karriere. Ole-Jørgen Skog og Elisabeth Bjørk fandt klar korrelation mellem alkoholforbrug og voldskriminalitet i Norge 1931-1982 og antog, om end med åbent blik for andre muligheder, indbyrdes kausalitet. J.Chr. Gjertsen: »Forbrytelser med døden til følge på Vestlandet 1950-1984« beskrev 140 sager i alt, heraf 118 efter 1965; Christies ord i 1969 »et umistelig gode « ved den norske kriminalitet, at den var så fredsommelig, var gjort til skamme. Riksadvokat Georg Fr. Rieber-Mohn, "Straffutmåling ved vold «, betegnede udviklingen især for forsætligt drab som urovækkende og anbefalede en udmåling mere inspireret af den strenge danske (12-16 års fængsel) end den milde svenske praksis (lige over 6 år). Leif Petter Olaussen refererede en opinionsundersøgelse i tre norske politikredse med dårlig dækning; af 7.000 svarede 4.235 , heraf 541 med offererfaring; $81,2 \%$ af alle havde tillid til politiet, dog kun $72,7 \%$ af ofrene.

Den i 1987 afdøde Ivar Strahl mindedes smukt af Alvar Nelson. Narkotikakontrollen i Finland blev beskrevet af Kimmo Hakonen og Osmo Kontula; der var få sager om grove overtrædelser d.v.s. over 500 gram cannabis, og ingen straf var 
strengere end 6 måneders fængsel. Ingstrup: »Elektronisk tilsyn« - det var første gang - tog både af etiske og praktiske grunde afstand fra denne kontrolform, som senere er indført i vidt omfang i Danmark. Og endelig beskrev professor Erich Buchholz fra DDR østtysk strafferet og kriminalpolitik, nærmest inspireret af défense sociale, idet straffens formål var at beskytte det socialistiske samfund og reintegrere forbryderen i dette; det var sidste udkald inden DDR's undergang. Som advokat efter 1990 forsvarede Buchholz de tiltalte, der havde dræbt »republikflygtninge« ved muren, med argumentet, at de dræbte var skyld i deres egen død ved blot at indfinde sig ved grænsen! Ikke den mest indtagende forfatter i NTfK's historie.

Vel halvdelen af årgang 1989 bestod af indlæg til det tiende nordiske kriminalistmøde i Stockholm.

Hovedemnet »Upplever fängelsestraffet en renässans?« havde tre indledere. K.J. Lång omtalte de særlige finske forhold, krigene, lange idømte straffe, men få dømte; han ønskede autonomi for administrationen, medens demokratisk kontrol fra politikere, der tænker i enkeltsager, medfører uacceptable krav om strengere straffe. Thorsteinn A. Jónsson beskrev de islandske erfaringer, hvorefter alle førstegangsdømte og alle for spirituskørsel dømte indtil 1978 blev benådet mod bøde på grund af mangel på fængselspladser; særlig spirituskørsel begås massivt, ca. 2.500 sigtede pr. år, 1,3 \% af befolkningen (svarende til 65.000 sager i Danmark!). »Jeg kan ikke få øje på noget, der tyder på andet end at frihedsstraffen har en lys fremtid. « Bo Svensson fremdrog de svenske erfaringer stik imod de finske, mange, men korte fængselsdomme; hverken tyveri eller vold ramte så hårdt som i det 19. århundrede; han ønskede derfor lavere strafferammer, bøde i stedet for frihedsstraf etc., snarere end manipulerende mellemformer som f.eks. samfundstjeneste.

Kallehauge: »Reaktioner over for psykisk afvigende lovovertrædere« påviste, at forholdsmæssighed havde sneget sig ind i praksis. Rieber-Mohn: »Miljøkriminalitet « fastholdt over for industriens ønske om forebyggelse snarere end straf, at netop på dette område forebygger straf, og almenpræventionen er særlig stærk. Klaus Helminen understregede, at varetægtsfængslingen rammer hårdere end straf, fordi den rammer uforberedt. Inger Nyström: »En effektivisering af straffprocessen i enklare brottmål«, nævnte anklagerens roller, »objektiv« undersøgelsesleder, »dommer« ved tiltalespørgsmålets afgørelse, hvor han ofte stiller for strenge krav, sluttelig part under domsforhandlingen. Helge Waal: »Kriminalvård eller socialvård for unge lovbrytere« advarede mod at lade stå til, »Ingen reaksjon er ingen god reaktion«. Törnudd: »Kriminologi och kriminalpolitik«, udtalte, at der ikke er definitive løsninger; den, der lover en mirakelkur, er enten en charlatan eller kræver en samfundsomstyrende hestekur, hvis pris vi ikke vil betale. Nordskov Nielsen gik ind på EMRK's store betydning for straffeprocessen, og så havde han endda ikke fået den epokegørende Hauschildtdom med, afsagt umiddelbart før mødet i Stockholm.

Blandt de øvrige bidrag i 1989 var smukke mindeord om Aubert af Christie samt historisk betonede artikler. Waaben sammenlignede straffene for vold og tyveri i 
historisk lys og sluttede, at problemet ikke er førstegangsstraffen, men de hårde gentagelsesstraffe for tyveri. Agnete Weis Bentzon: »Frygtelige tider og frygtsomme jurister « tog udgangspunktet i de tyske juristers svigten 1933-1945 og trak paralleller til danske jurister. Dommerfuldmægtig ved landsretten i Godthåb Henrik Garlik Jensen gengav grønlandsk kritik af de milde straffe og anklagemyndighedens lave strafpåstande på grund af manglen på anstaltspladser i Grønland, herunder et grønlandsk Herstedvester. Det synes som om de grønlandske holdninger ikke længere var præget af mildhed (se under 1977). Alvar Nelson mindedes den internationale kriminalistforenings 100 års jubilæum, dens efterfølger Association Internationale de Droit Pénal og tilsvarende foreninger.

Vigtigst i årgang 1990 var et stort hæfte i anledning af den finske straffelovs 100 års-jubilæum. Träskman indledte og havde bearbejdet og til dels oversat bidragene. Dan Frände skrev om klassikeren Honkasalo og den totalitære strafferet; Honkasalo var fortrolig med den nazistiske strafferet, men sympatiserede ikke med den; han gik ind for racehygiejne, men det var almindeligt tankegods i tiden (i Danmark Steincke og Goll). »Förutsebarhetens betydelse inom Honkasalos läran om kausalitet i straffrätten « af Kimmo Nuotio dyrkede især det intrikate adækvansproblem, f.eks. i det klassiske eksempel, hvor A afleverer en kasse til skibstransport og opgiver indholdet som kaviar, men fortier, at der er sprængstof $i$ kassen. Den ansatte B taber culpøst kassen med en sprængningsulykke til følge. Hvem har ansvaret? Ari-Matti Nuutila: »Möjligheten att handla annorlunda som en förutsättning för skuldansvar«, fremdrog Allan Serlachius og hans debat med den sociologiske skole. Jussi Pajuoja: »Ungdomsvåld «, beskrev som det uhyggeligste angreb, incl. drabshandlinger, rettet mod ukendte og tilsyneladende motiveret af et ønske om at virke maskulin og »tough«. Kjell Sevón: »Legalitet, effektivitet och legitimitet som kriterier för straffrättens normativa koherens«, tog udgangspunkt i en teori om retten som »förstelnad politik«.

Blandt andre bidrag var Otto Christensen m.fl.: »Fjerndrab, et nyt fænomen«, der i Danmark havde iagttaget det samme uhyggelige fænomen i praksis som Pajuoja i Finland. Kjell-Inge Bjørvik kritiserede »Boomerangsagerne« i Bergen, hvor flere, der havde afgivet forklaring om politivold, senere selv blev anklaget og til dels dømt for falsk anklage eller forklaring. Den amerikanske professor Gene M. Lutz undersøgte kriminalpolitiske holdninger i det danske Folketing, hvor de mest udbredte straffeteorier var ønsker både om resocialisering og om opretholdelse af offentlig orden og sikkerhed, men ikke gengældelse. Karsten Revsbech: »Kommunalbestyrelsesmedlemmers strafbare medvirken til borgernes lovovertrædelser i dansk ret« omtalte bl.a. en sag, hvor jeg dømte en viceborgmester for medvirken til ulovlige rituelle slagtninger ved at overlade de slagtende en 
kommunal bygning. N.G. Stoiko udtrykte i »Den sovjetiske strafferetspleje under ændring « et forsigtigt håb til fremtiden, læseren kunne mærke, at denne artikel var skrevet i Gorbatjovs periode. Peter Garde: »Erfaringer fra Kronebanksagen« skildrede en meget stor dansk sag om økonomisk kriminalitet, her en mellemstor banks undergang på grund af uforsvarlig långivning.

I årgang 1991 afløstes Svensson som svensk redaktør af högskoleadjunkt Lena Holmqvist. I Slettans og Øies oversigt over norske domme refereredes to afgørelser i Treholtsagen, og det fremgik, at diverse aspekter af denne sag havde nået Høyesterett i alt 13 gange! Mest interessant i Lindegaards oversigt over danske domme var 5 sager, hvor Højesteret måtte afveje, om et påberåbt hensyn til informationsformidlingen kunne føre ellers retsstridige handlinger begåede af journalister uden for det strafbares område, hårfine afgørelser, ikke sjældent med dissens. Britta Kyvsgaard noterede et vanskeligt forklarligt fald i børne- og ungdomshypotesen; forskere har nævnt kohorte-, kontrol- og disciplineringshypotesen. Kirsten Sørensen skildrede elektronisk overvågning i et amt i Californien nødvendiggjort af fængslernes voldsomme overbelastning, op til 5 i samme celle; emnet var højaktuelt over for de danske overvejelser om et tilsvarende system.

W. Frees Christiansen påviste, at selvmordsraten i danske fængsler ikke er højere end uden for fængslerne; en særlig alvorlig sigtelse kan dog være en selvmordsdeterminant. Trude Brita Nergård: „De norske konfliktrådene - et eksempel på symbolpolitikk?«, besvarede dette spørgsmål bekræftende, måske overraskende for den udenforstående; hun undrede sig over, at ordningen nu blev lovfæstet, selvom den havde virket så dårligt. Fængselsinspektør Hans-Jørgen Engbo talte til fængselspræster om »Demokratiske og etiske fordringer til fængslernes magtanvendelse «, bl.a. kritiserede han, at man ikke udleverede rene sprøjter gratis til narkomanerne. Frank J. Porporino m.fl. beskrev »Kognitiv oplæring i canadiske fængsler«, i ikke ringe grad er Canada inspirationskilde for os. Endelig gennemgik Verner Kaae Dansk Ingeniørforenings omhyggelige bygningsmæssige normer om teknisk forebyggelse af kriminalitet - også det er kriminalprævention.

Årgang 1992 indledtes med Lisbeth Bangs redegørelse for en nyoprettet helsetjeneste i Oslo for voldtægtsofre; de umiddelbare tal tydede på, at både tallene for anmeldelse og domfældelse var steget. Garde behandlede især praksis om afhøring af børn til et videoapparat og hævdede som praktiker børns generelle troværdighed som vidner, herunder i de belastende sædelighedssager, på linie med Beth Grothe Nielsen, der på grundlag af nyere forskning punkterede myterne om løgnagtige børn og forførende, fantasifulde pubertetspiger. Kauko Aromaa påviste, at den europæiske integration, herunder indvandring fra Vestrusland og 
Randstaterne, har medført en stigende kriminalitet i Finland. Clemens Stubbe Østergaard beskrev den overhåndtagende guandao, embedsspekulation eller korruption, i Kina som resultat af markedsreformerne samt de af studenter anførte demonstrationer rettet imod embedsmænds profitmageri.

Anette Storgaard sammenholdt norsk og dansk narkotikastrafferet og bekræftede en hypotese om, at forbrydelserne i de to broderlande meget ligner hinanden, herunder med en ret stor andel udlændinge blandt de hårdest dømte, men at straffene i Norge er langt strengere end i Danmark. Knut Papendorf fortalte, at en tysk Landgericht $i$ en ankesag om indsmugling af en smule hash i et fængsel havde erklæret forbudet mod hash, men ikke mod alkohol og nikotin, grundlovsstridigt som en krænkelse af Grundgesetz' lighedspræmis og beskyttelse af personlighedens udfoldelse (i 1994 erklærede den tyske Forfatningsdomstol forbudet for grundlovsmæssigt, bortset fra besiddelse af en ringe mængde til eget forbrug). Ragnhild Schlüter kritiserede kriminaliseringen af »det reisende folk«, »fantene « i Norge. Blandt andre rædsler i Rubya Mehdi: »Islamisering og dens indflydelse på kvinders retlige situation « om ret og uret i Pakistan var, at manglen på lovfæstet bevis for voldtægt - tilståelse eller fire rettroende mandlige øjenvidner - kan medføre piskestraf til anmelderinden for utugt, da bevismæssig gråzone åbenbart er ukendt. I et samfund med mange indvandrere er det vigtigt at kende de etniske gruppers retlige baggrund. På et spinkelt statistisk grundlag, tyve kvindelige indsatte, beskrev Berit Vegheim »Kvinners møte med politiet«; hovedindtrykket af de grundige samtaler var, at den gængse hypotese om politiets større ridderlighed over for kvinder ikke stemmer; bl.a. syntes kvindelige politibetjente særlig hårdhændede over for de indsatte kvinder, som næsten alle kom fra narkotikamilieuet, næsten som var der en speciel gensidig antipati. Og så holdt Bratholm et foredrag ved den norske forenings 100 års-jubilæum og gjorde status for arbejdet med en ny norsk straffelov. NTfK har fulgt de store straffelovskodifikationer til dørs.

Også årgang 1993 behandlede børn som ofre, kvinder som ofre og dømte og muslimske forhold. Tony Olesen m.fl. gennemgik samtlige 90 video-optagede afhøringer af børn anmeldt for at have været udsat for seksuelt misbrug 1986-1991; det ses, at ordningen er vel indarbejdet. Hauge og Jens J. Guslund samt Anette Storgaard satte spørgsmål ved den gængse antagelse om, at kvinder behandles særlig mildt i retssystemet; antallet af sager var dog så småt i begge tilfælde, at det undrer mig, at man mente at kunne drage videregående slutninger på et så lille grundlag. Malene Frese-Madsen redegjorde for den eksplosive udvikling i ofrenes rettigheder i straffeprocessen i USA, således retten til at afgive en forklaring om, hvordan forbrydelsen har opvirket dem, victim-impact statement, inden straffastsættelsen. Kjersti Ericsson behandlede fra et feministisk udgangspunkt di- 
lemmaet mellem at være skyldfrit offer og passivt objekt eller handlende subjekt og dermed medskyldig i overgrebet. Lasse A. Warberg: »Shari'a: Om den islamiske strafferetten (Uqûbât) « gav et billede af, hvad forfatteren kalder en levende, praktiseret hellig ret; det »rettsoptimistiske« syn, at afhugning af blot én tyvs hånd kan forhindre alle senere tyverier, er naivt, men ligeså naivt er det at forsøge at forstå islamisk ret uden at have in mente, at shari'a anses som lex divina, gudgiven ret.

Eva Smith nævnte vanskelighederne ved at opnå tilstrækkelig information om afgørelserne fra den europæiske menneskerettighedsdomstol og foreslog et udvalg med opgave at dissekere disse afgørelser. Garde skrev om EDB og de straffeprocessuelle tvangsindgreb på grundlag af en tysk fremstilling, første gang emnet behandledes i NTfK. Coen Mulder og Karen ten Hove påpegede den internationale retshjælps retssikkerhedsproblemer i forbindelse med det intime samarbejde mellem strafhåndhævelse og skattevæsen i Holland. Iain Cameron skrev om nordisk international strafferet på grundlag af en frisk betænkning fra 1992. A. Kørner, Kramp og Gorm Gabrielsen refererede 69 mentalundersøgelser af ikke sindssyge, men psykisk afvigende og praksis om anvendelse af psykiatriske særforanstaltninger, som hyppigt anvendtes, med mindre den begåede forbrydelse var særlig alvorlig såsom drab. Den største indsats i denne årgang ydedes af Träskman, udover at han fortsat var finsk redaktør, $78 \mathrm{pp}$. af 336 var hans, først en boganmeldelse, dernæst to lange, samhørende artikler om M. Cherif Bassiounis forslag om en international straffedomstol, som han var skeptisk overfor, især fordi han frygtede, at Norden ville blive presset til deltagelse i en repressiv kriminalpolitik, som vi internt havde arbejdet os væk fra, endog med nykriminalisering af forbrydelser som udbredelse af pornografi. Væsentligst var hans $34 \mathrm{pp}$. lange finske krönika, den første siden 1982. Nordisk indstillede kriminalister har af sproglige grunde ingen mulighed for at sætte os ind i finske kilder, så ildsjæle som Träskman, der omhyggeligt opretholder forbindelsen ved at bringe de væsentlige efterretninger på svensk, er af aldeles afgørende betydning.

Første hæfte af årgang 1994 var tilegnet Alvar Nelson på 75 årsdagen, 13 kriminalpolitiske studier fra alle de nordiske lande, heraf hele 6 fra Finland. Vel i anledning af emnet for Nelsons disputats Rätt och ära omhandlede to af bidragene den i vore dage meget forsømte overtrædelse ærekrænkelse, Eero Backman: „Kan vetenskaplig kritik vära ärekränkning?« om den meget lille mulighed for at rejse injuriesag på grundlag af en anmeldelse - falsk beskyldning for plagiat vil dog nok være strafbar - og Toftegaard Nielsen: »Ærekrænkelser - behandles de groveste seriøst af myndighederne? « med fremdragelse af tre sager, hvor meget 
grove beskyldninger, to endog for drab, blev behandlet meget lemfældigt af anklagemyndigheden.

Næste hæfte indeholdt indlæg til det elvte nordiske kriminalistmøde i København. Träskman havde emnet en international straffedomstol og var fortsat skeptisk. Hvis denne domstol anvendte dødsstraf, burde de nordiske lande nægte overhovedet at deltage. Efter hans mening ville den kun have symbolværdi. Stein Ulrich betonede det dynamiske og levende samarbejde i det politisk uafhængige Interpol; europæisk integration medførte øget kriminalitet, bl.a. bandeopgør Tallin havde højere drabsfrekvens end Detroit; der var modstand mod at afgive kompetence fra det nationale politi og bekymring for borgernes retssikkerhed. Owe Horned fastslog, at både humane og praktiske hensyn talte for overførelse af udenlandske strafdømte til afsoning i hjemlandet, men at der var problemer i det lidet rationelle ubetingede krav om den dømtes samtykke og store forskelle i strafniveauet i domslandet og afsoningslandet. Marianne Håkansson var pessimistisk med hensyn til justitsvæsenets muligheder over for den voksende kriminalitet, optimistisk over for internationalt kriminologisk samarbejde, men ønskede udover den angelsaksiske verden åbning mod de romanske lande, også sprogligt. Balvig: »Kriminologi som nationalt modarbejde« krævede forskning på indenlandsk stof, hellere egne iagttagelser fra fængsler og politistationer end ophold på udenlandske universiteter. Internationale kriminologer ophørte i værste fald med at forske. »Det bliver kun til lidt skriveri og opkog på gamle papers i fly og tog på vej fra det ene møde til det andet.«

Thór Vilhjálmsson var koncentreret om EMRK art. 6, især Unterpertinger-sagen og afledet praksis om bevisførelse. Jeg er usikker på, om et krav om ligestilling mellem parterne som af ham antaget kan læses ud af art. 6. Han påpegede, at oplæsning af politirapporter ikke i sig selv er en konventionskrænkelse, men først en domfældelse alene på dette grundlag. Rentzmann påviste, at nøje efterlevelse af alle etiske krav fra Den europæiske Torturkomité og FNkonventionen om barnets rettigheder kan skade mere end det gavner; således kræves det, at en »habil« fanges beslutning om sultestrejke skal respekteres til det yderste, hvor midlertidig overflytning til et civilt sygehus muligt kunne redde ham. Greve: »Forholdet mellem EU-strafferet og national strafferet«, advarede mod centralt udstedte påbud, der vil blive opfattede som en magtdemonstration, og udtrykte en for en lærling af Ross uventet sympati for det 19. århundredes historiske skole; identifikation af neutrale eller fælles områder og vedtagelse af ens love, der kan accepteres, er vejen frem. Lars Oftedal Broch: »Kriminalitetens internasjonalisering «, beskrev forbrydernes evne til omstilling til grænseoverskridende kriminalitet, bl.a. hvidvaskning, og politiets og retsvæsenets store vanskeligheder ved at skabe et samarbejde; helt godt lykkes det kun mellem de nordiske lande indbyrdes.

Udover kriminalistmødet var det vigtigste bidrag i årgang 1994 en 41 pp. lang islandsk kronik af Ragnheidur Bragadóttir, den første i 11 år, indeholdende mængder af oplysninger om de store ændringer i retspleje- og straffelovgivningen, vigtigst adskillelsen af retspleje og forvaltning på underretsplan. Thorsten Sellin døde og blev mindet af Preben Wolf. Kristin Skjørten påviste svagheder i retssystemets behandling af sager om kvindevold; en undersøgelse fra 1986 viste, at $76 \%$ 
af alle sager henlagdes, bla. fordi anmeldelsen blev trukket tilbage, og da ubetinget offentlig påtale blev indført, nægtede mange voldsramte hustruer at afgive vidneforklaring. Paul Larsson: »Samfunnstjenesten sett fra innsiden«, viste, at sanktionen har gode aspekter, og at den bestemt oplevedes som straf af de dømte. En meget lang anmeldelse af Paul Leer-Salvesen: Menneske og straff var underskrevet »Dansk drabsdømt strafafsoner«, nok den eneste anonyme artikel i NTfK's historie; anmeldelsen var klar over, at der ikke er tilgivelse for drab, men håbede på Guds nåde.

Leif Petter Olaussen, jfr. 1988, havde to lange artikler i årgang 1995, »Voldskriminalitetens utvikling de to sidste tiårene« og »Angst for voldskriminalitet $\mathrm{i}$ Norge«. Han fremhævede særlig den strengere praksis om familievold, til tider udover hvad de voldsramte kvinder selv ønskede. En dreng på 1 år 9 måneder havde bidt sin fader i fingeren, og smerten fra biddet fik faderen til at knipse sønnen på munden, så læben hovnede op og der kom et lille sår, der blødte, på indersiden. Høyesterett idømte bøde $1.000 \mathrm{kr} . !$ Angstundersøgelsen bekræftede, at ældre kvinder, der så godt som aldrig udsættes for vold, havde den største frygt for vold. Garde havde ligeledes to artikler, en indførelse i det nye bevismiddel DNA, som nu er blevet så brugt i den praktiske efterforskning, og »Ny fransk straffelov«, der afløste Napoleons gamle Code pénal fra 1810. Ketil Skogen og Lars Wichstrøm: »Kriminalitet og klasse«, mente at kunne konstatere i det mindste en tendens til, at lovovertrædere fra de laveste klasser har større risiko for at blive afsløret af politiet; jeg vil her henvise til, at deres »ungdomskulturelle« adfærd bringer dem lettere i politiets søgelys.

Ted Goldberg: »Den svenske narkotikapolitiken«, gik ikke ind for liberalisering, men han var mistrøstig over for overoptimistiske bemærkninger om, hvor godt den svenske model virkede, og mente, at der igennem 1980'erne var sket en betydelig nyrekruttering af unge til det tunge misbrug. Hans Boger: »Narkotikapolitikk og moral«, påviste, hvor meget mindre skade der var indtruffet i tiden 1800-1910, hvor adgangen til narkotiske stoffer var meget let. Via Kant, Schopenhauer og utilitarismen nåede han til, at den repressive stofpolitik, som skaber så mange ulykker, er umoralsk. Papendorf fulgte sin tidligere artikel om de tyske overvejelser om grundlovsmæssigheden af hashforbudet op. Astrid Holgerson: »Sexuella och rituella övergrepp«, kritiserede aktuelle sager med børn som vidner, og fremhævede som særlig uheldigt den norske Bjugn-sag, hvor børn, der først havde nægtet fuldstændig, at der var sket noget, derefter afhørtes efter »hvis«-metoden »men om han har gjort något med dig, hur kan det ha gått til?« Jeg er enig, en sådan afhøringsteknik bør ikke accepteres. Jaakko Jonkka skildrede den igangværende reform af den finske straffeproces; en rigsretssag var opta- 
get til dom efter afhøringer og procedure på fem successive dage! Arkitekt Beate Ellingsen fortalte om overvejelserne om udformningen af retssalene i det nye Oslo Tinghus, og den flittige pensionist Waaben skrev »En fængselsreform på tegnebrætter omkring år $1800 \ll$.

Fra hæfte 3/1995 stod på omslaget »med støtte af Nordisk Samarbejdsråd for Kriminologi« efter »Udgivet af de nordiske kriminalistforeninger«, og English Summaries blev almindelige.

I årgang 1996 var Beth Grothe Nielsen gæsteredaktør på et hæfte engelsksprogede artikler, bl.a. to russiske og en lithauisk, en engelsk og en amerikansk. Hovedindtrykket var pessimisme på grund af den stadig stigende fængselspopulation efter kortvarige forhåbninger, da fangetallet faldt i Østeuropa umiddelbart efter Murens fald. I U.S.A. var fængselsindustrien så populær, at tidligere lokale protester imod et fængsel i nærheden (»Not In My Back Yard «, NIMBY) var afløst af tilbud om byggegrunde. Thomas Mathiesen betonede massemediernes ødelæggende indflydelse på det kriminalpolitiske klima. Ingstrup gøs ved tanke om, at privat fængselsindustri fra U.S.A. fik indpas i Canada, og hudflettede de mest katastrofale deviser i århundredets kriminalpolitik »Nothing works « og »Just deserts«. Effektfuldt sluttede hæftet med optryk af en optimistisk kronik af Karl O. Christiansen fra 1972, hvor man stadig troede på nedkriminalisering, »Om at affolke fængsler«.

I tråd med tendensen i Beth Grothe Nielsens samling var hendes egen artikel i et senere hæfte »Behandling i seksualforbrydere - den canadiske model«, hvor hun skildrer og anbefaler vidtgående behandlingsprogrammer af afsonere, der er delvis taget som model i Herstedvester. Ida Elisabeth Koch påviste, at regelsættet muliggør intensiv psykiatrisk behandling som alternativ til afsoning af fængselsstraf, men at ressourcerne mangler; hun anbefaler, at staten, ikke kommunerne, tager ansvaret og betaler for disse behandlinger. Det logiske endepunkt nåedes $\mathrm{i}$ Espen Schaaning: »Strafferettens sjel«, det eneste rene abolitionistiske bidrag jeg har læst i NTfK; hans synspunkt er en overkonsekvent anvendelse af in dubio pro reo, hvor han tager Andenæs til indtægt og hævder, at da vi aldrig kan være sikre på den subjektive skyld, har vi ingen ret til at straffe.

Helgi Gunnlaugsson gennemgik islandske undersøgelser, der viste, at medens det praktiske kriminalitetsbillede ikke havde ændret sig, var befolkningen mere optaget af forbrydelser nu end tidligere; læseren noterer, at økonomiske forbrydelser ikke endnu var anset som et problem. Pia Rudolfsson beskriver den svenske virkelighed, hvorefter tilbagefald medfører strengere straf for den nye overtrædelse, og den rejste kritik af, at gerningsmanden på denne måde straffes dobbelt for den første overtrædelse. Henrik Belfrage: »Serievåldtäktsmän« viser be- 
tydeligt tilbagefald for svenske sædelighedsforbrydere uanset arten af den anvendte sanktion, med en undtagelse, dømte, der har gennemgået langvarig gruppebehandling, har lavere tilbagefald; den undersøgte gruppe var dog endnu for lille til at drage definitive konsekvenser. Årets mest fantastiske historie var den finske rigsretsproces, nævnt under 1995. Handels- og industriminister Juhantalo fra Centerpartiet fik for at have afkrævet en bank millionbestikkelse et års fængsel betinget og blev udstødt af rigsdagen, men genvalgt ved næste valg med et stort personligt stemmetal!

Fra årgang 1997 afløstes Träskman, som efter en periode i København nu var ansat i Lund, som finsk redaktør af Frände, men blev sideordnet svensk redaktør. Årgangens vigtigste bidrag var internationale. Hans Göran Franck: »Häkten och fängelse hos Europarådets medlemsstater«, oplyste om problemer omkring varetægtsfangerne, bl.a. overbelægningen og de mange udenlandske fanger. Christie: "Straffens geografi«, oplyste om fangetal, både den gode nyhed om nedgangen i tallene fra Finland, nu på linje med de andre nordiske lande, og de uhyggelig store tal i Rusland og U.S.A. med over en million fanger hvert sted. Lev Samoilov: »Lejrens etnografi« beskrev på grundlag af sin egen afsoning for en politisk overtrædelse fangelejrens sociologi, rangordningen i »tyve« (de ledende), »bønder« (de mange) og »tryner « (de udstødte) og det uhyggelige liv for bønder og tryner. Paulina Tallroth sammenholdt lovgivningen om svangerskabsafbrydelse i Norden og Tyskland med vægt på de intertyske forskelle efter genforeningen, hvor adgangen til abort havde været meget friere i DDR end i Vesttyskland. Peter Kruize kritiserede den nordiske opfattelse, hvorefter Hollands kriminalpolitik præges af stigende strenghed, og hævdede, at der var kommet mere alvorlig kriminalitet, i vidt omfang begået af etniske udlændinge; antallet af fængselsdomme var uændret, men de enkelte dommes varighed større. Helgi Gunnlaugsson: "Kriminaliteten i Island: Internasjonalt perspektiv«, påviste - udover de store mængder af især spirituskørsel - den beskedne og meget uvoldelige kriminalitet, bl.a. på grund af Islands fredelige historie, herunder at frigørelsen fra Danmark blev vundet ved logik og argumenter uden voldelig kamp.

Vigtigst var to modstridende bidrag, af hovedredaktør Greve med effekt sat efter hinanden, Ulrich Sieber (oversat til svensk) argumenterede for en harmoniserende modelstraffelov for hele Europarådets område, ikke blot for EU, især med argumentation, at forbrydelser som bl.a. datakriminalitet og milieuforbrydelser var blevet internationale, og at strafferet og strafhåndhævelse derfor ikke burde være standsede af de nationale grænser. Derimod advarede Träskman mod EU-projektet »Corpus juris« med forslag om en fælles straffelov og straffeproces, særlig en fælles anklagemyndighed, til behandling af sager om svindel med fæl- 
lesskabsmidler; bl.a. påviste han, at dette kan medføre, at der i samme straffesag kan være to konkurrerende anklagere. I 2013 er der gået ca. 15 år siden »Corpus juris« fremtrådte, uden at der er set skridt til gennemførelse deraf.

I årgang 1998 fik Greve sit festskrift som Anttila og Nelson før ham. Blandt de 15 forfattere - 7 danske, 4 finske, 2 norske og 2 svenske - var Jareborg, der oversatte Corpus juris' tekst og i en fodnote henviste til en kritisk rapport fra Uppsala, initieret af ham selv, hvor han i stedet foreslog specialiserede nationale organer og bedre international retshjælp. Beth Grothe Nielsen hævdede, at selektionen ikke kun udvælger enkelte blandt de mange forbrydere, men også blandt ofrene, at det ofte er tilfældigt, hvem der hos politiet får status af offer og hvem som forbryder, samt at de samme personer kan være først forbrydere, så ofre, som da en løsladt dobbeltmorder blev offer for røveri og dødsvold. Toftegaard Nielsen påviste, hvorfor det er nemt at dømme »kulier«, men vanskeligt at ramme forbrydelser i erhvervslivet, uden at det er nødvendigt at forudsætte ond vilje hos de bestemmende. Britta Kyvsgaard viste, hvordan et fald i ungdomskriminaliteten ledsagedes af en mærkbart hårdere behandling af de unge overtrædere, der blev anholdt. Ståle Eskeland spekulerede på grunden til, at O.J. Simpson trods de overvældende beviser mod ham alligevel kunne frifindes af en jury, som lokket af forsvarets demagogiske veltalenhed lod sig påvirke af sekundære elementer som f.eks. at en ledende efterforsker var racist. Träskman kritiserede tendenser i retning af omvendt bevisbyrde, særlig den nye danske $§ 76$ a om konfiskation af ikke blot bevist udbytte, men også af den dømtes øvrige formue eller endog hans hustrus eller samleverskes formue, medmindre det kunne bevises, at midlerne var erhvervede lovligt; også Greve har ivret imod denne regel. Pekka Koskinen gjorde status for den så godt som afsluttede finske strafferetsreform.

I resten af årgangen vil jeg fremhæve en stor islandsk, en svensk og en norsk artikel. Thórdis J. Sigurdardóttir og Hildigunnur Olafsdóttir beskrev vold mod både kvinder og mænd på grundlag af 3.000 spørgeskemaer og svarprocent på 74. 9,4 $\%$ af mændene og 2,8 \% af kvinderne havde været udsat for vold, mændene mest uden for hjemmet og halvdelen af kvinderne i hjemmet. Ekstrapolation på hele befolkningen viste, at 1.000-1.100 kvinder og ca. 650 mænd havde været udsat for vold fra ægtefælle eller tidligere ægtefælle. En dansk undersøgelse viste lidt mindre vold end i Island. Thor Norström kortlagde praksis efter en nylig lovændring om rattfylleri, som tilsigtede - og havde medført - langt færre straffe af ubetinget fængsel og hensyntagen til andre faktorer end promillen, særlig kørslens karakter. Elisabet E. Storvoll og Arild Hovland skildrede unge kriminalitetstruedes besøg på Ullersmo landsfengsel, hvor fangerne skræmte livet af dem, »Scared Straight«. Senere evalueringer viste meget tvivlsomme resultater af disse konfrontationer, og jeg er enig med kritikere som Mathiesen, der forkaster projektet af etiske grunde. 
Redaktionen blev næsten totalt udskiftet. I 1998 afløstes Lena Holmqvist af professor Hanns von Hofer, og i årgang 1999 afløstes Greve, Thormundsson og Christie af Britta Kyvsgaard, docent Ragnheidur Bragadóttir, dr. philos. Hildigunnur Olafsdóttir og professor Kjersti Ericsson. K.J. Lång, død i 1998, mindedes af Träskman især for sin indsats ved nedbringelsen af fangetallet i Finland. Den mærkeligste artikel dette år var Torkil Lauesen: »Vridsløselille Statsfængsel set i fangeperspektiv« på grundlag af hans egen afsoning (løsladt i 1996) af 10 års fængsel for deltagelse i Blekingegadebandens meget alvorlige forbrydelser. Forfatteren, som konsekvent betegner sine forbrydelser som politiske, afviser en dobbeltrolle for betjenten som vogter og socialrådgiver, hylder fangernes »modmagt« og bagatelliserer problemet stærke fanger, idet han omtaler fanger fra rockerbanden »Hells Angels« meget positivt. Artiklen er velargumenterende og velskrevet, men jeg er ikke glad ved at se en sådan mand udfolde sig som ekspert i NTfK.

Christie: »Forebyggelse« beskriver pessimistisk et opdelt samfund, hvor de, der har noget, ikke blot adskiller sig, men forskanser sig. Sven-Åke Lindgren: »Prioriterede och negligerade offer«, omtaler en overset offergruppe, ofre for økonomiske forbrydelser; ofte anmelder de ikke, til tider anses de som medskyldige, »ofre med smudsige hænder«; kun den ressourcestærke stat reagerer, særlig på skatte- og afgiftsforbrydelser. Ross er genstand for to artikler, som strafferetsdogmatiker af Jareborg og som strafferetsfilosof af Nuotio. Jareborg kritiserer Ross' moralistiske linie, der kun anerkender aktiviteter, ikke præstationer, som betingelser for straf og bortser fra skadens indtræden - drabsforsøg er ligeværdigt med fuldbyrdet drab - hvilket udvider det strafbares område uacceptabelt vidt. Nuotio anerkender Ross' kamp mod determinismens opgivelse af skyldkravet, som ville fjerne enhver grænse for statens kontrollerende magtbeføjelser, og betegner Ross som forløber for nyklassicismen. De nordiske kriminalisters bedste ven i Tyskland Karin Cornils: »Om lokalisering af brott på Internet«, afviser lokalisering og dermed straffemyndighed overalt hvor en ytring på internettet kan læses, og foreslår en binding til det fysiske handlingssted plus det sted, hvor den anvendte server er opstillet (også dansk straffelov tilstræber en begrænsning).

Den danske forenings 100 års jubilæum blev fejret med en jubilæumskonference, åbnet af justitsminister Frank Jensen, udnævnelse af Waaben som æresmedlem, tre store foredrag, festmiddag på Børsen og en historisk fremstilling af Garde om de 100 år som et særnummer af NTfK. Nordskov Nielsen: »Bølger i den kriminalpolitiske udvikling«, gennemgik hele århundredet fra de første små reformer af 1905 via straffeloven af 1930 og ophævelsen af de fleste tidsubestemte foranstaltninger i 1973 - som han nægtede at kalde behandlingstankens sam- 
menbrud - til de sidste årtiers politiserede kriminalpolitik, som han stod lidt usikker over for og harmedes ved for så vidt angik strafskærpelserne. Christie: »Hvordan er Danmark mulig?« kombinerede en hjertelig lykønskning til Danmarks kriminalpolitiske stabilitet, ikke flere fanger end for 100 år siden trods kriminalitetens udvikling, med en advarsel til både Danmark og Norge om farlige tendenser, herunder lovgivers forsøg på at binde dommeren med minimumsstraffe, så dommeren risikerede at blive blot og bar sekretær for lovgiveren. Biskop Niels Henrik Arendt: »Straf og menneskesyn«, skrevet med god hjælp fra hans fem arresthuspræster, fastholdt, at ethvert menneske bør behandles som en uundværlig, der kan yde noget til samfundet; han forkastede ikke straf, men straffen måtte ikke tage værdigheden fra mennesker, hverken indsatte eller ansatte. - Det var en herlig dag!

Årgang 2000 indeholdt tre bidrag om dødsstraf. Martin Bergqvist: »Dödsstraffet i U.S.A. - Allmänpräventivt eller brutaliserande« konkluderede, at der hverken er bevis for, at dødsstraf afskrækker, eller at den genererer flere mord. Bergqvist anmeldte også en bog af Alexander S. Mikhlin om dødsstraffen i Rusland med lidet underbyggede argumenter for dødsstraf. Jukka Lindstedt resumerede sin finsksprogede disputats om dødsstraf i Finland under 2. verdenskrig. 522 sovjetiske og 157 finner blev dødsdømt, 443 og 85 henrettet, flest for spioneri, hvilket jeg modsat forfatteren ikke vil kritisere, fra gammel tid er døden den lod, der venter den tilfangetagne spion; forfatteren anerkendte, at retshandlingen $\mathrm{i}$ feltkrigsretterne i hovedsagen var tilfredsstillende.

Gunnlaugsson: »Kriminalitet og straffepolitik i Island« påviste, at frygten for kriminalitet var steget, men at kriminaliteten stort set var uændret igennem ti år. Hauge: »Folkehelseperspektivet og liberaliseringen av nordisk alkoholpolitikk« påviste, at siden opmærksomheden i højere grad rettes imod alkoholens skadevirkning for brugeren selv end virkningen på andre, er en restriktiv alkoholpolitik sværere at fastholde. Tapio Lappi-Seppälä viste, at nedgangen i fangetallet i Finland ikke har medført mere kriminalitet; ganske vist er denne gået op, men ikke mere end i Danmark, Norge og Sverige; kun tallet for drab giver anledning til bekymring. Träskman (nu i Sverige) m.fl.: »Tio år med straffvärdet«, debatterede anvendelsen af »straffvärde« $\mathrm{i}$ retssalens virkelighed; jeg savner ikke begrebet for Danmarks vedkommende.

Ved det tolvte nordiske kriminalistmøde i Oslo dette år fremhævede Lahti, efterfulgt af Henry John Mceland, efter den historiske fremstilling af behandlingstankens storhedstid og tilbagegang den stigende internationalisering og europæisering, »ett hot eller en möjlighet?«. Thomas Mathiesen kritiserede de nye kontrolforanstaltninger, især på europæisk plan, hvis formål i højere grad 
var kontrol med uønskede fremmede end kriminalitetsbekæmpelse. Waaben og Christie skrev om styring med straf. Waaben anbefalede en fortsat udvikling i formildende retning, især anvendelse af samfundstjeneste, hvor han ønskede overgrænsen stadig forskudt opad, medens Christie som strafferetlig »minimalist« på ny anbefalede civile forlig i konfliktrådsregi samt tilgivelse snarere end straf og med åbne øjne accepterede den uundgåelige retsløshed (Garde: »Tilgivelsens begrænsning«, modsagde). Hauge: »Har narkotikapolitikken spilt fallit?«, svarede $\mathrm{ja}$, hvis en politik udover færre brugere medfører øgede skadevirkninger for brugerne. Politimester Bjørn Hareide kaldte politiet en kulturinstitution, der tog vare på, anvendte og formidlede grundlæggende værdier af betydning for samfundet, og krævede, at politiets måde at nå sine mål på samsvarede med retssamfundets etiske grundlag og moralske krav. Rikspolitichef Heckscher sekunderede og fremhævede forskningens betydning for politiarbejdet. Frände krævede proportionalitet mellem skaden ved vidtgående efterforskningsmetoder som aflytning, infiltration og skinkøb og midlernes nyttevirkning; han anerkendte bevisprovokation, men afviste »buggning «. Bertel Österdahl fremdrog udlændingenes overrepræsentation blandt forbryderne og i fængslerne, hvor de ikke er problematiske fanger; han ønskede bedre programmer for de indsatte, som skal udvises. Førstestatsadvokat Inger Marie Sunde ønskede mere debat om de nødvendige regler til sikring af bevis i sager om EDB-forbrydelser.

Vigtigst i årgang 2001 er det af Britta Kyvsgaard redigerede hæfte om »Samfundssanktioner i Norden«, skrevet af hende selv, Lappi-Seppälä, Ragnheidur Bragadóttir, Paul Larsson og Jane Dullum samt Träskman. Forskellene er store, og man kan med hende spørge, om opløsningen af den nordiske strafferetskomité i begyndelsen af 1990-erne har medvirket til, at de fem lande i enkeltheder går deres egne veje, skønt hovedlinierne fortsat er ens. Fælles for alle var indførelse af samfundstjeneste som alternativ til hovedsagelig ubetinget dom, besluttet af retten bortset fra Island, hvor Fængselsdirektoratet efter eget skøn omsætter den af retten idømte ubetingede straf, med føje kritiseret af Ragnheidur Bragadóttir. Mægling i konfliktråd, hvor Christie præger norsk debat, måske ikke praksis, og ungdomssanktioner anvendtes eller planlagdes i flere lande. Träskman påpegede, at det svenske udgangspunkt, »just desert« efter forbrydelsens »straffvärde«, i praksis var blevet til over 20 forskellige sanktioner ved de mange kombinationsmuligheder, så man nærmede sig en individorienteret sanktionsfastsættelse, uden at dette afspejledes i teorien og ideologien.

Vagn Greve beskrev den nye danske straffuldbyrdelseslov på et område, der tidligere var reguleret af spredte regler. Normalitet, selvforvaltning, orden og sikkerhed, skånsomhed, nærhedsprincip inspirerede den nye lov. I stedet for domstolskontrol sås en stadig styrket ombudsmandsinspektion. Samtidig indførtes adgang til prøveløsladelse for livstidsdømte efter 12 års afsoning og domstolsprøvelse, såfremt prøveløsladelse nægtes efter 14 års afsoning. Nuotio skildrede EU's stadig mere intensive arbejde med strafferetten fra det europæiske råds mø- 
de i Tammerfors i 1999 og beslutningen om at publicere en resultattavle om både planer og resultater; først et forslag om menneskehandel, både udnyttelse af underbetalt arbejdskraft og prostitution. Den defensive nordiske kriminalpolitik kom i skyggen af EU's mere repressive og direkte politik. Hofer understregede metodeproblemerne ved alle sammenligninger; ICVS (International Crime Victims Survey) syntes bedst. Träskman kritiserede en avisundersøgelse med sammenligning af straffen i ti fiktive sager i Norden, Tyskland og Holland, som især syntes at vise et lavt dansk straffeniveau for voldtægt, og som udløste skærpelse af voldtægtsstraffen, gennemført i 2002.

I årgang 2002 - hvor Frände afløstes som finsk redaktør af Nuotio - omtalte Thomas Elholm samme spørgsmål som Nuotio i 2001. Af argumenterne for en europæisk harmonisering af strafferetten anerkendte han kun symbolværdien, men pegede på farer, hvis hvert medlemsland forsøgte at få de andre lande til at opfylde dets særlige kæpheste. Birgit Feldtmann: »Anklagemyndighedens rolle nogle komparative tanker om legalitet og opportunitet i det danske og det tyske retssystem«, påviste forskellene mellem danske og tyske regler, men også de ikke uens resultater i praktisk retspleje, når man gik i dybden. Europæisk harmonisering, endog en europæisk anklagemyndighed, var mere end vanskelig i lyset af de grundlæggende og indarbejdede forskelle, selv mellem to retssystemer, som står hinanden så nært som Danmark og Tyskland. Hofer grunder over, at fangetallet $\mathrm{i}$ Holland fra 1975 til 2001 steg fra 19 til 95 fanger pr. 100.000 indbyggere, medens de nordiske lande lå fast omkring 60-65. Skærpelsen skyldtes i høj grad et pres fra vælgerne og en frygt for forbrydelser, måske også en eksistentiel uro og en følelse af utryghed.

Sakari Melander drøftede berettigelsen af kriminalisering, kravet om berettiget interesse, »rättsskydd«, om nødvendighed, ja om ultima ratio, om nytte- og skadebaseret afvejning og om proportionalitet. Også finsk var Henrik Linderborg: »Samhällstjänsten som ett självdisciplinerande straff«, grundige interviews med 28 samfundstjenestedømte. De fleste betonede tvangen og straffen ved tjenesten, som givetvis var mere tyngende end en betinget dom; »Raimo« tilføjede dog som et positivt element, at straffen tvang til en vis rytme og »noggrannhet« og muliggjorde et normalt liv. Yngve Carlsson: »Forebyggingskjøkkenet«, opremsede i en noget søgt metafor velfærdskommunens ekspansion i den sidste generation og de mange nye problemer. Garde fastholdt bedømmelsen af børn som troværdige vidner og var modsat svensk praksis skeptisk mod vidnepsykologer i retten.

Vigtigst i årgang 2003 var en kolossal norsk kronikk af Asbjørn Strandbakken - 50 pp., 253 slutnoter - en nøje gennemgang af arbejdet med en ny norsk 
straffelov, der slutter sig til tidligere årganges dyrkelse af de danske, svenske og finske straffelovsforslag. Han var stort set anerkendende, men på enkelte punkter kritisk, som da kommissionen forsøgte at »snikinnføre« aktiv dødshjælp og her undlod at nævne en central forfatter (Erling Husabø), hvis synspunkter gik imod kommissionen. Strandbakken har kloge ord om Stortingets magt over strafudmålingen; nok har lovgiver det sidste ord, men domstolene har ansvaret for de lange linier, og politiske tilkendegivelser er ofte bygget på et mangelfuldt fundament.

Andenæs døde og blev mindet af Träskman, der bl.a. fremdrog hans vise ord: »Straff må ikke brukes i unøden.« Toftegaard Nielsen, Strandbakken og Träskman: »Om selskabsansvar i Norden«, på tre sprog og dækkende alle fire lande, drøftede en dansk sag, hvor en arbejder kom alvorligt til skade ved egen uagtsomme tilsidesættelse af de ham indskærpede sikkerhedsregler; straf idømt arbejdsgiveren/selskabet i Danmark, men kun der; i Sverige er der ikke engang hjemmel til at pålægge en juridisk person straf. Heini Kainulainen påviste, hvordan tiltalefrafald var blevet en del af den praktiske virkelighed også i Finland; betænkeligheder forelå kun, hvis vold i familien blev sluttet i uacceptabelt omfang. At videnskaben ofte blot bekræfter, hvad vi mente at vide i forvejen, viser Anker Brink Lund: »Kriminalitet i danske massemedier«; tyveri m.v., som udgør størstedelen af anmeldelserne til politiet, spillede en forsvindende ringe rolle i massemedierne, bortset fra lokalpressen, medens mord og alvorlig vold fylder særlig fjernsynet, i lidt mindre grad aviserne. Garde: »Halvfjerds år for Rakel - om reformer i nævningesystemet«, opridsede reformbehovet for den danske jury; »70 år« svarede til tiden fra løftet om nævninger i 1849 til retsplejeloven i 1919 og kom omtrent til at svare til tiden fra de første reformkrav i 1940 til den senere reform, i kraft fra 2008. Peter Scharff Smith: »Isolation og sindssygdom - Vridsløselille forbedringshus 1859-1873 « skildrede fanger, der blev sindssyge af årelang isolation, hvilket system først ophørte i 1930'erne; jeg er enig med forfatteren i hans kritik af de historiske forhold, men kan ikke følge ham i, at disse skadevirkninger er afgørende argumenter mod kortvarig isolation af varetægtsfængslede.

Vigtigst i årgang 2004 var det trettende nordiske kriminalistmøde i Helsingfors, indledt med en smuk tale af republikkens præsident Tarja Halonen, selv tidligere student hos Anttila, og som fremhævede det internationale og europæiske strafferetlige samarbejde. De to plenumemner slutter sig til Helsingforsmødet i 1984, »Brottsutvecklingen i de nordiska länderna 1980-2002 tendenser och förklaringar samt brottspreventionens roll« (Aromaa, Balvig, Gunnlaugsson, Hauge, Jan Andersson) og »Utvecklingen av de straffrättsliga påföljderna i de nordiska länderna« (Lappi-Seppälä, Greve, Bragadóttir, Magnus Matningsdal, Agneta Bäcklund). Det første emne gav et kalejdoskopisk billede, stagnation i Danmark og Sverige, stigning i de andre lande, men forbedret registrering, særlig i Finland, kunne farve billedet; den klareste tendens var en 
eksplosiv stigning i narkotikaforbrydelserne, måske også vold, men her kunne det lavere mørketal på grund af stigende anmeldelseshyppighed spille ind. Det andet emne viste ens tendenser $\mathrm{i}$ de fleste lande, strengere straffe, til dels forhøjede minima, for alvorlige forbrydelser, selv Finland var efter mange års nedsættelser af fangetallet ramt af den »punitiva populismen « med forhøjelse af fangetallet på $30 \%$ til følge, men også øget brug af ikke-frihedsberøvende straffe, især samfundstjeneste, endog de ubetingede fængselsstraffe for promillekjøring i Norge var i vidt omfang erstattet af betingede domme, tvungen deltagelse i kurser m.v. Greve: »Fra indgrebsret til strafferet«, beskrev de mange forvaltningsretlige sanktioner for ulovlige handlinger og advokerede inddragelse af de fundamentale strafferetlige principper i hvert fald for de alvorlige indgreb som fratagelse af erhvervsmuligheder.

Blandt sektionsemnerne fortalte Kirsti Nieminen en trist historie om en nærmest uforbederlig ungdomsforbryder, hvem det nok var gået bedre, hvis de sociale myndigheder havde taget sig anderledes effektivt af ham fra barndommen. Träskman drøftede, ikke uden sympati, om strafferettens almindelige del, f.eks. definitionerne af forsæt og uagtsomhed, burde lovfæstes som sket i vidt omfang i den nye finske straffelov eller fortsat overlades teori og praksis, men også om sociale hensyn m.v. burde medføre ændring af de generelle principper, f.eks. om nødværge burde omdefineres for at beskytte kvindeinteresser, herunder om nødværge mod et forventet senere angreb skal legitimeres. Erling Johannes Husabø: »Strafferetten og kampen mot terrorismen«, den anden nynorske artikel i NTfK, drøftede presset på uskyldspræsumptionen og retten til domstolsprøvning ved sortlistning af organisationer og indefrysning af deres midler, indgreb som det norske menneskeretsinstitut har kaldt »criminal charge « i relation til EMRK artikel 6. Elholm fremhævede betænkelighederne ved EU-samarbejdet på strafferettens område, især de stærke krav om meget vidtgående gensidig anerkendelse af afgørelser og angrebet på princippet om dobbelt strafbarhed.

Uden for kriminalistmødet modsagde Olaussen: »Hvorfor er kriminalitet en sosial realitet?« Christies påstand om, at »Kriminalitet finnes ikke«, og påviste med Durkheim og en nyere filosof Tranøy, at et samfundsmæssigt magtorgan har legitim ret til at gribe ind over for onde handlinger. Paulina Tallroth godtgjorde, at retten til at bruge eget sprog i retten ikke er ubegrænset; Ragnhild Sollund: »Spesiesisme - fenomenets grunnlag og konsekvenser« (species = art) satte mishandling af dyr bl.a. ved slagtning i principielt perspektiv. Vægtigst var den veldokumenterede »Benådning på grund af psykisk lidelse - diagnoser, kriminalitet m.v. i dag og for 35 år siden« af Kramp og Gabrielsen. 50 \% af ansøgerne nu var skizofrene m.v., mere end dobbelt i forhold til to grupper fra ca. 1970, ligesom 75 $\%$ af ansøgerne nu havde et misbrugsproblem mod kun $25 \%$ i det ældre materiale. Alle skizofrene m.v. blev naturligvis benådet, men retten burde aldrig have idømt dem en ubetinget straf i første omgang, og de burde have været mentalundersøgt.

Første hæfte i årgang 2005 omhandlede prostitutionslovgivning i de nordiske lande, af Greve, Johanna Niemi-Kiesiläinen, Bragadóttir, Ulf Stridbeck, Träsk- 
man og Nell Rasmussen. Fra et fælles udgangspunkt, indgreb mod den prostituerede kvinde af hensyn til sædeligheden, af medicinske grunde og socialforsorgsgrunde, derpå afkriminalisering af kvindens forhold, bortset fra Island, var udviklingen nu gået hver sin vej, særlig om spørgsmålet, om prostitutionskunden skulle straffes. Et strafbelagt forbud var gennemført i Sverige og var ved at blive gennemført i Finland, men endnu ikke i de andre tre lande. De folkelige holdninger gik også hver sin vej, i Finland og Sverige støttede måske 80 \% kriminalisering af »sexkøb«, men i Danmark kun $21 \%$. I november 2012 har den danske justitsminister fulgt Straffelovrådet og afslået at fremsætte lovforslag om et forbud. Träskman: »Den som betalar for sex är en brottsling« kritiserede skarpt den svenske lov. Han oplyste, at Socialstyrelsen, Domstolsverket, Riksåklagaren, Justitiekansleren og Rikspolisstyrelsen havde frarådet loven, påviste, at den store politiindsats kun afstedkom få sager på grund af de indbyggede bevismæssige og juridiske vanskeligheder, og hævdede, at loven ikke opfyldte kravene til nykriminalisering, især at straf var den eneste mulige løsning, ultima ratio-argumentet.

Blandt de øvrige artikler i 2005 var Dag Hareide: »Politiets konflikthåndtering i Norden« og Paul Larsson: »Kriminalitetsforebygging og politirollen«, der begge understregede den bløde del af politiets arbejde, internt kaldet »bamsepolitiet«; bl.a. foreslog Hareide opmærksomhed omkring politiets kropssprog. KnutFredrik Hustad omtalte en debat om TV-udsendelse af retssager, efter at Høyesteretts ankebehandling af Orderudmordsagen var blevet vist på norsk TV; de juridiske deltagere i debatten betonede faren for trivialisering og anførte bl.a., at mediets interesser ikke var sammenfaldende med rettens mål om sandhedssøgning. Anders Nilsson påviste, at løsladte fanger var langt svagere nu end før, allerede fordi de ikke opfyldte betingelsen for samfundstjeneste eller elektronisk fodlænke; også andelen af udlændinge var vokset (fra 20 \% i 1992 til 27 \% i 2002). Felipe Estrada: »Våldsutvecklingen i Sverige 1974-2002« påviste på grundlag af et meget stort materiale, samtlige hospitalsindlæggelser efter vold, at efter dette kriterium havde volden ikke været stigende i perioden; der var dog mørketal ved, at henvendelser, der ikke kom videre end tandlægen eller akutmodtagelsen, ikke indgik i materialet. Träskman gennemgik i anledning af en nylig betænkning betingelserne for genoptagelse, et i teorien forsømt emne.

I årgang 2006 skrev Mika Illman om kriminalisering af Holocaustbenægtelse, der måske kan rammes som »hets mot folkgrupp« i Sverige og Finland, medens Danmark afviser strafbarhed. Peter Lindström havde læst en mængde amerikanske artikler og studeret et svensk eksperiment, hvor Örebros politi modsat Eskilstuna anvendte nultolerance. Han konkluderede, at det var ubevist, om nultolerance havde virkning, jeg er enig. Berit Johnsen og Birgitte Langset Storvik gen- 
nemgik norsk praksis om den nye forvaring, som synes at blive anvendt langt mere i Norge end i Danmark, måske til dels fordi Danmark modsat Norge har bevaret livstidsstraffen for de alleralvorligste forbrydelser. Ragnheidur Bragadóttir havde efter opfordring udformet nye skærpede regler om voldtægt og sædelighedsforbrydelser mod børn, som kunne forventes at blive gennemført i Island. Jussi Matikkala gav i »Dolus nordicus« et nyttigt vue over forsætsbetingelserne i de nordiske lande. Modsat ham tror jeg ikke på fællesløsning, forskellene er for store, særlig Vestnordens anerkendelse af sandsynlighedsforsæt modsat Sverige og Finland. Fhv. dommer Niels Viltoft problematiserede aftaler med anklagemyndigheden, særlig om nedsat straf som modydelse for forklaring om andre.

Henrik Tham advarede med føje mod at udfinde ofre til alle overtrædelser, også dem, der tidligere var betragtet som offerløse. Hvor gerningsmanden $\mathrm{i}$ 1970'erne ansås som et offer selv, var den offerorienterede kriminalpolitik nu konstrueret som et nulsumspil, hvor offerets tab gjordes til gerningsmandens gevinst. I samme retning viste Olaussen, at opinionsundersøgelser med samme spørgsmål viste en mere punitiv holdning i 2004 end i 1989, bortset fra Osloområdet. Hofer viste, at volden i Sverige var udbredt i det 19. århundrede, lav mellem verdenskrigene og stigende siden ca. 1960, men at anmeldelser og omdefinition af tidligere accepteret adfærd som vold var steget end mere på grund af mindsket tolerance for smerte og øget følsomhed for vold; endog pornografi ansås som vold! Minna Kimpimäki: »Nationella tolkningar av universalitetsprincipen« beskrev den nyeste udvikling i dette princips udformning særlig i de nordiske lande, bl.a. det praktiske problem, om strafforfølgningen i det mindste kræver, at den sigtede aktuelt er til stede i landet. Lars Korsell: »Ekonomisk och organiserad brottslighet« skildrede med en omfattende litteraturgennemgang udviklingen i synet på de to kriminalitetsformer og foreslog, at opmærksomheden ikke rettes ensidigt mod strafforfølgning for begåede forbrydelser, men i højere grad mod forebyggelse. Stefan Holgersson m.fl.: »Anmälningar mot poliser« udgik fra den store stigning i tallet på anmeldelser, ifølge en studie på 995 til 1.875 på 10 år, hvoraf kun 1,4 \% resulterede i dom; bestræbelser på at ændre den enkelte politimands adfærd var mere frugtbare end udsigtsløs retlig undersøgelse.

Årgang 2007 var på grund af et stort antal indlæg til det fjortende nordiske kriminalistmøde i Stockholm vokset til $480 \mathrm{pp}$.

I det første plenum havde den svenske riksåklagare Fredrik Wersäll en vision om et grænseløst Norden, endog således at det ene lands politi kunne gå over grænsen og foretage en anholdelse (artikel i årgang 2006), ligesom Gustaf Möller, Finland, fastholdt, at der trods EU-samarbejde var grundlag for endnu tættere nordisk samarbejde på strafferettens område, bl.a. at en beslut- 


\section{Peter Garde}

ning i det ene land skulle kunne lægges til grund i de andre lande uden prøvning. I det andet plenum, »Kränkande uttalanden och yttrandefriheter - vad är brottsligt att säga?« talte Eva Jagander: »Hate speech?« om to svenske afgørelser, bl.a. sagen om pastor Åke Green, hvis udfald mod homoseksuelle i en prædiken af Högsta Domstolen blev anset som ikke beskyttet af Sveriges grundlovs regel om ytringsfrihed, men af den europæiske Menneskeretskonvention EMRK. Ragna Aarli uddybede med udgangspunkt i sagen »Tønsberg Blad mod Norge« pressens vidtgående ytringsfrihed i EMD's praksis. Greve kritiserede overbevisende kriminaliseringen af Auschwitzløgnen, den strafferetlige beskyttelse af hele grupper som i dansk straffelovs $\S 266 \mathrm{~b}$ samt retspraksis' overdrevne hensyntagen til de krænkende ytringers form. Björg Thorarensen betonede udvidelsen af ytringsfriheden i Strasbourgs praksis, men også de nye udfordringer for multikulturelle samfund, når grupper kræver straf for krænkelse af deres religøse følelser.

De 20 indlæg om de 12 sektionsemner vidner om nordisk kriminalistiks spændvidde. Frände: »Aktuell straffrättsutveckling inom EU. Harmonisering och ömsesidigt erkännande«; bevisernes frie bevægelighed var et problem. Kyvsgaard og Birgitte Göransson: »Kundskabsbaseret kriminalforsorgspolitik « fremhævede "Scared Straight" som et markant eksempel på et direkte skadeligt program. Agneta Bäcklund og Jesper Ryberg bemærkede, at forskning og viden er ideelt set objektiv, men kriminalpolitik er værdibaseret, udsat for politisering og tryk. Lars Korsell og Anne-Mette Dyrnes udtalte, at de svenske mørketal for korruption var store, idet mange offentligt ansatte blev udsat for bestikkelsesforsøg uden at modtage dem, men også uden at politianmelde dem. Iain Cameron: »EU's sanktionssystem mot terrorism«; optagelse på den sorte liste i FN's sikkerhedsråd eller EU's ministerråd uden retlige garantier var et menneskeretligt problem. Aina Mee Ertzeid og Tham påviste forskellene mellem Vest- og Østnorden med hensyn til ofrenes retsstilling og de norske bestræbelser på at udvide ofrenes rettigheder. NiemiKiesiläinen beskrev de svenske vidnebeskyttelsesprogrammer og den menneskeretlige debat om anonyme vidner.

Harald Strand skildrede den norske strafrabat for tilståelser, og Petter Asp problematiserede plea bargaining. Gabrielsen og Kramp nævnte, at antallet af retspsykiatriske patienter stiger ca. $15 \%$ om året, og en medvirkende grund kan være det stadig faldende antal psykiatriske sengepladser. Lappi-Seppälä fandt i de nordiske konsensusdemokratiers velfærdssamfund en forklaring på de milde straffe sammenlignet med det øvrige Vesteuropa og især U.S.A.; Ulla Bondeson var enig og påpegede, at trygheden medførte en mindre punitiv holdning. Hrefna Fridriksdóttir accepterede det dobbelte system for de 15-18 årige, børneværn og straffesystem, men ønskede bedre samarbejde mellem disse; Stina Holmberg ønskede et rent præventionsprincip. Elina Pirjatanniemi fastholdt af etiske grunde forældelse af samtlige forbrydelser, selvom DNAbeviset nu muliggør opklaring af meget gamle sager - i 2005 førtes en sag om et tredobbelt mord år 1960 - og Romtraktaten om den internationale straffedomstol udelukker forældelse for folkeretlige forbrydelser, hvorimod Petra Lundh godtog afsmitning på svensk ret med udelukket forældelse for de alvorligste forbrydelser.

Mødet sluttede med en paneldebat: »Likhet inför lagen«, Garde hævdede, at fuld lighed i strafudmåling er umulig, forkastede positiv særbehandling af etniske minoriteter og konstaterede, at personer fra disse ved ikke at tilstå påførte sig selv en strengere behandling; Robert Spano fastholdt, at anklagemyndighedens tiltalebeslutning er undergivet gængse forvaltningsretlige grundsætninger, herunder risiko for at blive erklæret ugyldig ved grove fejl; Ragnhild Hennum 
påviste, at bedre sociale forhold medførte bedre mulighed for prøveløsladelse, men ville ikke kritisere dette.

Uden for kriminalistmødet havde Träskman to artikler; i den ene beskrev han den europæiske arrestordre og kritiserede, at den var ensidigt orienteret imod effektivitet snarere end individets retssikkerhed. I den anden, »Var finns Forsete?« [Forsete var retfærdighedens gud i den nordiske mytologi] gennemgik han de vægtigste indlæg fra de nordiske kriminalistmøder og gjorde gældende, at årene 19501990 var nordisk kriminalpolitiks guldalder, men at guldalderen var endt på grund af dels EU-lovgivning, dels et hårdere klima med strengere straffe og særlig en udvidet brug af fængsel. Lindström havde læst amerikanske studier om loven »Three-Strikes and You're Out«, d.v.s. en ekstremt streng straf ved tredje dom, også foreslået i Sverige; han konkluderede, at der ikke var belæg for, at loven havde en præventiv virkning. Estrada m.fl.: »Det ökade våldet i arbetslivet« (d.v.s. kunders/klienters vold mod især offentligt ansatte) konstaterede i en omhyggelig studie en stor stigning i denne vold, og at særlig kvindelige ansatte var mere udsatte i de seneste år; omvendt var volden kun sjældent politianmeldt. Susanne Clausen: »Har samfundstjeneste en præventiv effekt? « besvarede nærmest spørgsmålet med ja; særlig arbejdsløse, hvis sociale bånd blev styrket ved sanktionen, recidiverede mindre end efter en fængselsstraf. David W.M. Sorensen: »Kriminalitetsrejsen. Om indbrudstyves mobilitet« bekræftede de også uden for Danmark gjorte erfaringer, at indbrudstyve bevæger sig over korte afstande, at antallet af forbrydelser aftager med afstanden fra tyvens bolig, at tyve vel af frygt for genkendelse undlader at begå forbrydelser i en bufferzone nær hjemmet, og at tyve ikke nødvendigvis opsøger velhavende kvarterer.

I årgang 2008 gennemgik Dan Helenius de intrikate spørgsmål om grænsen mellem »ne bis in idem« og »lis pendens«, en verserende, men ikke afsluttet sag om samme forhold. Forsell m.fl.: »Från kelgrisar till styvbarn - fusket med välfärdssystemen« skildrede udviklingen i det svenske syn på socialbedrageri, som oprindelig blev benægtet, ja fortrængt, men nu tages alvorligt af begge fløje i det politiske spektrum. Peter Koudahl beskrev en spørgeskemaundersøgelse om de danske indsattes uddannelsesmæssige forudsætninger og ønsker. Toivo Jokkala: »»»Man märker att folk tycker olika, men på papperet ser det ut som om alla tycker samma sak.« En intervjustudie om nämndemän i tingsrätten« bekræfter citatet i titlen; svenske dommere og nämndemän tilstræber og opnår konsensus ofte efter grundige forhandlinger, hvor meningerne bøjer sig mod hinanden; af 9.370 straffedomme i Stockholms tingsrätt i 1992 var $97 \%$ enstemmige; der var 
en vis om end ubekræftet frygt for, at nämndemän fra sverigedemokraterne ville politisere retternes virke.

Garde: »Den norske ankeprøvning (»siling«) i straffesager set fra Danmark« drøftede på grundlag af observationer på stedet de særegne norske procesregler og overvejede deres relevans for Danmark. Annika Suominen omtalte en principiel dom om lovligheden af den europæiske arresteringsordre og den voksende europæisering af strafferetten i Lissabonaftalen. Lindström hævdede, at en forøgelse af det svenske fangetal på $10 \%$ havde medført $5 \%$ færre tilfælde af dødsvold, og en tidligere mindskning på $10 \%$ havde medført $4 \%$ flere indbrud i boliger. Medens kriminologer understregede fængselsstraffens skadelighed, fandt økonomer, at straffen reducerede forbrydelser. Hofer betvivlede Lindströms resultater. Snorri Örn Árnason og Gunnlaugsson: »Etisk dilemma i det islandske forretningsmiljø resumerede interviews med ti islandske mellemledere i virksomheder, der afslørede en hårdere indstilling og en større risiko for økonomisk kriminalitet. Marie-Lisbet Amundsen resumerede interviews med ti indsatte i norske fængsler, alle med mindst syv fængselsophold, nogle med mere end tolv; alle afslørede deres ensomhed, afmagt og angst; enkelte var ligefrem tilfreds med at være i fængsel, så kunne man i det mindste tale med betjentene.

Torben Trances: »Den uformelle straf og velfærdsstaten« konstaterede, at den fængselsdømte var marginaliseret fra arbejdsmarkedet både før og efter afsoning, men at det sociale sikkerhedsnet mildnede indtægtstabet. Moa Forsberg: »Rätt utan Sanning « [konsekvent med stort S] spurgte, om det moderne retsvæsens bestræbelser på overensstemmelse mellem virkelighed, bevisførelse og ret var blevet problematiseret ved en postmoderne anerkendelse af, at begge stridende parter havde et virkelighedsbillede. Ud fra en imponerende beherskelse af emnets historie fulgte Per Ole Johansen sine tidligere 12 titler op i »Organisert kriminalitet - Hva nå?«; løsere organiseret kriminalitet florerede og var måske blevet hyppigere, men på det øverste, politiske plan var Norge fortsat ukorrupt. Kyvsgaard: »Gaderøveri« analyserede 1.911 røverier; de fleste ofre og gerningsmænd var meget unge (en røver var knap 7 år!), udbytter var ofte små, og spænding og ønske om at vise dominans var et hyppigt motiv. Pål Lagestad afdækkede en til tider svigtende færdighed i fysisk arrestationsteknik hos politiet og efterlyste bedre uddannelse på området. Paul Larsson tiltrådte som ekstra norsk redaktør.

Waaben døde og blev mindet af Rentzmann i årgang 2009. Larsson og Dan Magnusson: påviste, at kontrollen med hvidvaskning koster ca. 400 mill. svkr. i Sverige og ca. 200 mill. nkr. i Norge, og at ingen præventiv virkning særlig med hensyn til primærforbrydelserne er godtgjort. Balvig og Kyvsgaard: »Man anmelder da vold?« godtgjorde på et kolossalt grundlag, i alt ca. 72.000 udspurgte, 
at anmeldelseshyppigheden på ca. 10 år var steget fra $36 \%$ af ofrene til $44 \%$, på grund af dels hyppigere anvendelse af genstande, især kniv, dels øget afstandtagen over for fysiske overgreb, herunder nedsat tolerance over for bl.a. værtshusvold og vold begået af piger. Solgunn Eidheim skildrede de menneskelige og praktiske omkostninger for voldsofre ved at bo på beskyttet adresse, særlig når en voldsmand har samkvemsret over for et fælles barn.

Den flittige Träskman havde også i denne årgang to artikler. I den første skildrede han den nordiske anklagers mange pligter, ikke mindst ved afgørelsen af trivialsagerne, der allerede på grund af deres mængde kræver, at de tages alvorligt; vigtigst er dog tiltalespørgsmålets afgørelse, når skylden ikke erkendes. I den anden beskrev han ofret som udløsende faktor, som bevisperson og mere forbeholden som næsten-part i et system, hvor straffeprocessen er orienteret mod konfliktløsning som bl.a. advokeret af Christie. John Pratt og Anna Ericsson forklarede de lave nordiske fangetal modsat England, New South Wales og New Zealand ved velfærdsstaten, den politiske kultur, konsensusdemokratiet og den historiske udvikling, der aldrig forkastede den stærke stat. Andreas Karlgren og Helen Örnemark Hansen: »Medling i brottmål som en del av det svenska straffrättssystemet« skildrer anvendelse af »restorative justice« på en gadevoldssag og drøfter, om konfliktløsningens antagelse af skyld kan harmonere med uskyldspræsumptionen som knæsat i EMRK art. 6, stk. 2. Johan Kardell og Karl-Magnus Carlsson viste en kraftig overrepræsentation af indvandrere og indvandrerbørn blandt de straffede i alle nordiske lande; ved kontrol for økonomiske og sociale faktorer aftog overrepræsentationen, men bortfaldt ikke.

Et hæfte på næsten 300 pp. med hele 21 indlæg til det femtende nordiske kriminalistmøde i København bragte årgang 2010 op på 520 pp., den hidtil største årgang.

Efter venlige velkomstord fra justitsminister Lars Barfoed og Rentzmann fulgte plenaremnet, Balvig, Gunnlaugsson, Kristina Jerre, Olaussen og Tham: »Den nordiske retsbevidsthedsundersøgelse« med det paradoksale resultat, at de adspurgte krævede generelt strengere straffe og i nogle foreviste sager foreslog en straf over hvad de troede retterne gav; det viste sig, at den idømte straf lå over den af dem foreslåede; jeg har svært ved at se, at disse resultater kan tages til indtægt for en strengere eller en mildere kriminalpolitik. Matningsdal: »Politikernes innflytelse på straffutmålingen« accepterede, at udtalelser om strafniveauet i direkte forbindelse med lovgivning følges af retterne, modsat udtalelser fra politikere uden for lovgivningen, som det er utilrådeligt at tage hensyn til.

I sektionsmøderne drøftede Anne-Stina Sørensen og Anders Danielsson (chef for SÄPO) fremtidens krav til politiet, efterlyste forskning og forudså treårig universitetsuddannelse af politimænd. James Bonta: „Understanding What Works: Lessons for the Nordic Countries?« skil- 
drede arbejdet i Canada med rehabilitering af forbrydere og det såkaldte Risk-NeedResponsivity program. Med udgangspunkt i en tysk sag i Strasbourg, der accepterer skjult overvågning, men kræver et effektivt kontrolsystem, gennemgik Nils Dalseide den omfattende kontrol på alle planer af den hemmelige ekstraordinære efterforskning i Norge. Estrada: »Våld som et (bra) samhällsproblem « hævdede, at vold, især begået af unge og personer med indvandrerbaggrund, mere end et ægte problem er et kunstigt skabt problem i massemedier. Inger-Lise Lien: »Bandekriminalitet og forebygging « skildrede pakistanske indvandrerbander i Oslo; selve migrationen var en makrofaktor af betydning for rekrutteringen; statens institutioner, særlig politiet, bør aldrig trække sig tilbage fra et farligt område, men tværimod styrke deres tilstedeværelse.

Träskman og Toftegaard Nielsen behandlede EMD's nye krav om positiv beskyttelse af borgernes menneskerettigheder med udgangspunkt i en bulgarsk voldtægtssag, hvor tiltale ikke var rejst, hvad EMD anså som statens manglende opfyldelse af sine pligter; de kritiserede, at tiltaltes krav på fair trial og ofrets krav på at få ham dømt begge anses som menneskerettigheder, hvor valget kan medføre krænkelse af både den ene og den anden ret. Greve og Frände behandlede bagatelovertrædelser og nultolerance, kritiserede overkriminalisering og ønskede hjemmel til at nøjes med advarsel, ja frifinde i de mindste sager, hvor tiltale aldrig burde være rejst. Martin Borgeke og Bent Carlsen omtalte strafudmåling; Borgeke ønskede bedre præjudikatsdannelse, måske »sentencing guidelines«, Carlsen nævnte lovgivers tilkendegivelser om strafudmåling i forarbejderne, hvilke retterne følger, men hvor motiverne kan være uklare, hvorfor lovgiver i videre omfang bør stille retterne frit. Korsell og Larsson beskrev organiseret kriminalitet; »broderskaber« som motorcykelbander er bedst kendt, men ad-hoc grupperinger er hyppigere. MayLen Skilbrei og Charlotta Holmström kortlagde nordisk prostitutionspolitik, hvor nu kun Danmark ikke straffer »sexkøb«. Claes Lernestedt: »Finns det grader i helvetet? Om köp (och försäljning) av sex« drøftede spørgsmålet om differentiering eller skabelonmæssig behandling af parterne samt forsøg på at gøre alle kvinder til erstatningsberettigede ofre. Jussi Tapani: »Island, finanskrisen och straffrätt - ett finländskt perspektiv « drøftede ligheder og forskelle mellem den islandske bankkrise og en finsk krise i 1980'erne og 1990'erne. Endelig behandlede Jon Petter Rui og Petter Asp ne bis in idem med særligt henblik på spørgsmålet, om administrative sanktioner udelukkede senere straffesag.

Veteranen Per Ole Johansen var gæsteredaktør på et tema om korruption, en artikel pr. land, Lars Bo Langsted om den retlige regulering i Norden, jeg savnede en dansk sag, f.eks. Brixtofte. Minna Viuhko: »Måste man alltid betala?« om den uundgåelige afpresning og korruption ved den finsk-russiske grænse. Margret Saemundsdóttir: »Sosioøkonomiske kjennetegn på den islandske politikken og bankstruktur« om svagheden ved et »mikroland«, hvor alle kende alle og favoritisme derfor må frygtes. Johansen selv: »I skyggen av det norske ikon« om fire store friske sager om korruption i norske kommuner; en af de største forbrydere havde fået Kongens fortjenestemedalje i gull, inden han idømtes fængsel i 8 år og konfiskation af 66 mill.kr.; den samlede historie om korruption i norske kommuner er ikke skrevet endnu, Johansen burde skrive den selv. Joakim Thelander: 
»Bofors-Indienaffären - ett fall av omdiskuterad svensk vapenexport«, ridser i lakken på ikonet Olof Palme; den schweiziske banksekretess skærmede de mulige forbrydere mod afsløring.

Nuotio afløstes som finsk redaktør af docent Jussi Matikkala. Lagestad og Hild Rønning anbefalede bedre viden hos de enkelte politimænd om det relevante regelværk, af særlig nytte når de afkræves en begrundelse af f.eks. en anholdt. Titlen på Paul Larssons artikel »Fra armesterke bondesønner til akademikerbarn - Om rekrutteringen til politiyrket« taler for sig selv; man spørger, hvad der er blevet af de armstærke bondesønner. Hofer: »Långsiktiga prognoser av platsbehovet på fängelser« forsøger tre forskellige trendmodeller med vildt forskellige resultater og når til sidst til det resultat, at en politisk ordre om niveauet af fængselspladser er »kostnadseffektivare«, når den ledsages af administrative foranstaltninger som regulering af ventekøer, øget eller mindsket udslusning og prøveløsladelse etc. Vigtigst var Greves mistrøstige konstatering af, at de nationale strafferetlige blandingssystemer har mistet deres kulturelle rødder og i voksende grad bliver præget af illegitime EU-retlige retselementer og tvivlsomme værdier; Montesquieu og Savigny påberåbes; jeg er aldeles enig med ham om, at det savner enhver fornuftig mening at hævde, at borgerne ikke har fri bevægelighed, hvis straffen for vold ikke er den samme i hele unionen.

Fra årgang 2011 blev Britta Kyvsgaard afløst som hovedredaktør af Thomas Elholm. Ekstra dansk redaktør blev lektor Lars Holmberg. Hofer og Träskman afløstes som svenske redaktører af professorerne Magnus Ulväng og Marie Torstensson. Hans Thornstedt døde og blev mindet.

Længst i denne årgang (63 pp.) var Tor-Geir Myhrer: »Sentervakternes polisiære fullmakter - Grunnlag og grenser« med udgangspunkt i det forhold, at store dele af handlen, ofte også vitale serviceorganer som banker, tandlæger, Tbanestationer, var beliggende på områder med offentlig adgang, men i privat eje, hvor privat ansatte vægtere opretholdt ro og orden. Især var Myhrer opmærksom på, om vægterne kunne bortvise og udelukke uønskede elementer. Han opstillede teorien om en urban allemandsret ad modum friluftsloven. På længere sigt foreslog han en begrænset politimyndighed til vægterne på linie med den engelske »Police Community Support Officer« snarere end den gældende usikkerhed.

Greve: »Retten og samfundet« var dybt pessimistisk i lyset af udviklingen i de seneste 20 år, hvor alle politikere gjorde en dyd af at være »tough on crime«. Skærpet overvågning, udlevering uden krav om dobbelt strafbarhed, nultolerance, endog »skærpet nul-tolerance«, Danmark nærmede sig politistaten. Et aspekt af overvågningen belystes i Michael Gøtze: »Retlige grænser for brug af straffeattester på arbejdsmarkedet«; 246.021 børneattester på 10 år, hvoraf 64 po- 
sitive; han foreslog lovgivning for at klarlægge grænserne. Jan Georg Christophersen belyste de alvorlige følger af fiskerikriminaliteten, bl.a. ved at lovbryderne indregistrerer deres fartøjer i stater, der ikke har tiltrådt de relevante konventioner; set udefra er det arbejde op ad bakke at håndhæve reglerne og forhindre ødelæggende overfiskning. Inger-Maria Sunde foreslog konfiskation, d.v.s. automatisk destruktion over internettet, af alle udsendte dubletter af især børnepornografi, »overgrebsbilleder«. Helen Ö. Hansen kritiserede individualisering bl.a. ved omsætning af livstidsstraffe; svenskere er mere lighedsorienterede end danskere, for mig at se kan livstidsdømte umuligt gøre krav på samme afsoningstid, en Anders Breivik eller en Palle Sørensen må sone længere end den, der »kun« har begået et enkelt mord.

Årgang 2012 havde hele tre temaer og otte yderligere artikler. Det første tema »Fundamentals of Criminal Law « bestod af engelsksprogede - undtagelsesvis indlæg fra et symposium i Bergen. Abstraktionsniveauet var højt. Wolfgang Frisch behandlede filosofiens indflydelse på europæisk strafferet og årsagen til både den basale ensartethed og de mange nationale forskelle. Frände behandlede den tyske »Rechtsgut«-teoris indflydelse på finsk ret. Linda Gröning opstillede en teori for »the criminal justice system«. Jørn RT Jacobsen behandlede andre videnskabers forhold til strafferetten; det valgte eksempel var placeringen af den kriminelle lavalder. Heike Jung: »Justice must be seen to be done « drøftede offentlighed i retsplejen med henblik på både den store del af retsplejen, der sker uden for offentlighedens kontrol, og problemet om fjernsynets tilstedeværelse.

Det andet tema, Svenska kriminalistföreningens 100-års jubilæum i 2011, gengav efter et digt af Tham om KRUM fem hinanden velsupplerende indlæg fra festmødet. Dag Victor: »Från behandlingsideologi till nyklassicism« gennemgik især skyldkravets genkomst; på ét vigtigt punkt overlevede behandlingsideologien, nemlig ved, at Sverige ikke krævede tilregnelighed som betingelse for strafansvar. Laila Freivalds: »Politikerna och kriminalpolitiken« gav som drastisk eksempel på partipolitikkens indtog i kriminalpolitiken, at justitieutskottet i 1970erne havde under ti »reservationer« pr. år, men i valgåret 1990-1991 hele 235! Kyvsgaard gav et rids over 100 års nordisk kriminalpolitik, incl. det nordiske samarbejde, men også de seneste års tegn på, at Sverige var blevet mere internationalt end nordisk orienteret; hun var klar over, at demokratiseringen af kriminalpolitikken havde berøvet kriminalistforeningernes liberale elite dens magt. Hofer omtalte de seneste års store stigning i fangetallet. Asp opridsede hele otte konsekvenser af, at strafferetten i vidt omfang kommer fra Bryssel, bl.a. at det ofte forhastede arbejde gør kvaliteten dårligere. 
Tre artikler omhandler politiuddannelsen. Kjersti Hove beskrev norske politibetjentes forventninger til deres kompetence og opfattelse af, i hvilket omfang de er opfyldt. Jonas Havelund m.fl. beskrev, hvorledes dansk politi efter de voldsomme uroligheder på Nørrebro i 1993 udviklede en bedre og dialogbaseret håndtering af masseforsamlinger, bl.a. ved at undgå eskalering af mindre episoder og alene skride ind over for identificerede uromagere. Silje Bringsrud Fekjor påviste, at mandlige politistudenter foretrak udadvendt arbejde som ordenspoliti og beredskabstjenesten, kvinder efterforskning og præventivt virke. Päivi Tillikka: »Avvägningen mellan yttrandefriheten och skyddet för privatliv i emd:s praksis lotteri eller enhetlig verksamhet?« afslørede usikkerhed og manglende forudsebarhed i EMD's praksis. Venla Roth beskrev vanskelighederne ved at udfinde ofrene for menneskehandel og opnå domfældelse; indtil nu var kun gennemført fem sager, heraf tre for sexuel udnyttelse; var kvinden rejst frivilligt til Finland med henblik på prostitution, kunne sag for menneskehandel umuligt gennemføres. Rasmus H. Wandall: „Styring af straffastsættelsen med domsbaser - Anklagemyndighedens Vidensbase « beskrev den nye vidensbase til supplering af de eksisterende praksissamlinger; særlig medtoges byretsdomme, ikke kun ankedomme.

Det sidste tema, regulering, indeholdt efter en indledning af redaktøren, professor ved Politihøgskolen i Oslo Paul Larsson - regler er der nok af, men implementeringen svigter - seks artikler. Korsell: »Ekonomisk brottslighet tur och retur « gennemgik de sidste 40 års udvikling i Sverige, de mange love og de mange nye myndigheder, men også vanskelighederne for den særlige Ekobrottsmyndighet; korruption og socialbedrageri spiller en stadig stigende rolle. Tage Alalehto foreslog forskellig indgriben mod forskellige forbrydere, især lejligheds- ctr. vaneforbrydere. Träskman: »Organiserad brottslighet, ekonomisk brottslighet och terrorism - hänger de samman? « besvarede spørgsmålet med ja for de to første indbyrdes, men nej for så vidt angår terrorisme, der er uden forbindelse med de to andre. Larsson og Vanja Lundgren Sørli fortalte om den betændte droskebranche, hvor måske et flertal kører »sort« trods indgribende og forfinet kontrol og streng straf ved afsløring; man siger endog, at »det å lure kontrollører i seg selv har en maskulinitetskonstruerende effekt«. Natalia Ollus og Anne Alvesalo-Kuusi: »From cherry-picking to control: migrant labour and its exploitation in Finnish governmental policies« fremdrog modsætningen mellem opmuntringen af indvandring og udnyttelse af mange indvandrere, endog i form af menneskehandel. Christophersen: »Beredskap og kontroll av maritim transport«, århundredets sidste artikel, dadlede norske myndigheders manglende efterlevelse af EFTA-regler om sikkerhed i havnene bl.a. mod terrorangreb, særlig kritisabelt efter terrorangrebet 22. juli 2011. 
Ved vejs ende aftegner der sig tydelige billeder. Et gennemgående tema er de store kodifikationer af de nordiske straffelove. De første årgange var fyldt med kommentarer til de danske udkast, så fulgte den svenske, den finske og senest den norske reform. De skiftende kriminalpolitiske strømninger ses tydeligt. Det første halve århundrede domineres af behandlingstanken, der godtager selv meget langvarig frihedsberøvelse - forvaring, sikring, internering - også for i sig selv mindre alvorlige overtrædelser; psykiatere optræder hyppigt som forfattere i denne periode, således Geill og Wimmer i Danmark. Almenpræventionen var dog aldrig lagt død, hvilket særlig ses i Andenæs' store artikel fra 1950. I 1960'erne begyndte reaktionen mod behandlingstanken, jeg fremhæver Christie: »Reaksjonenes virkninger« i 1961, Andenæs' anmeldelse af Börjesons »Om påföljders verkningar« i 1966 og Inkeri Anttilas: »Konservativ och radikal kriminalpolitik i Norden« i 1967, der gjorde afkriminalisering til det store krav som bl.a. afspejlet i debatterne i den svenske og den danske kriminalistforening i 1970 og 1972 om behandling af butikstyveri, snatteri. I den næste periode dominerede debatten om nyklassicismen, fra den svenske betænkning Nytt straffsystem, angrebet af Ulla Bondeson i 1978 og senere af Madeleine Löfmarck og lige så kraftigt forsvaret af Jareborg og von Hirsch. I de seneste år har internationaliseringen og europæiseringen af strafferetten fyldt spalterne. Mange har taget udviklingen for givet, men væsentlige forfattere har advaret, særlig Träskman i afvisningen af »Corpus juris« i 1997 og Vagn Greve i 2010.

Ikke blot den kriminalpolitiske udvikling, men også den almindelige historie afspejles i tidsskriftet, især Verdenskrigene, fra kongressers aflysning og Union internationales opløsning over »den store Omvæltning« i Tyskland i 1933, de finske dødsdomme og henrettelser og de norske og danske retsopgør efter befrielsen, i de senere perioder europæiseringen og indvandringerne. Reformerne ophørte dog aldrig, Granfelt og Arvelo kunne med stolthed rapportere om reformer i det krigsførende Finland og Honkasalo meddele, at kriminaliteten ikke var steget trods krigen.

Britta Kyvsgaards konstatering om kriminalistforeningernes og den liberale elites tab af magt, særlig i takt med politiseringen af kriminalpolitikken, er givetvis korrekt. Det er ikke efter indstilling fra Dansk Kriminalistforening, at straffeloven ændres ved stadige strafskærpelser næsten hvert eneste år. Men er magten tabt, er tidsskriftet stadig det centrale organ for den nordiske kriminalvidenskab i videste forstand. Mange af de største kriminalister har fyldt det trofast og vedholdende, udover de allerede nævnte er de vigtigste forfattere formentlig Hurwitz og Karl O. Christiansen, kriminologiens store pionér. Andre kunne nævnes, Alm- 
quist og Hartvig Nissen for indtrængende appeller til menneskelighed, Goll kulminerende med den kriminalpsykologiske studie om Peter Kürten i 1931, Bratholm, Per Ole Johansen for hans nette afsløringer fra Norges offentlige liv, alt for få nævnt, ingen glemt. Tidsskriftet blev aldrig et ensidigt partiblad, i mange år åbnede det med lige gæstfrihed sine spalter for de største modpoler i de 100 års historie, Andenæs og Christie. 30.-40.000 sider er det blevet til. Omvendt må det erkendes, at mange fremtrædende kriminalistiske forskere og forfattere ikke har dyrket tidsskriftet, og her vil jeg ikke nævne navne; måske var det uundgåeligt, i nyeste tid findes der modsat 1913 kriminalistiske tidsskrifter i hvert land med mange flere abonnenter og dermed en større indenrigsk læserkreds end NTfK.

Et nordisk tidsskrift kan ikke bestå, uden forfattere fra alle fem lande skriver i det. Heldigvis har ikke blot danske, norske og svenske forfattere fyldt det, efterhånden er både Finland og Island kommet godt med, selvom de ikke kan benytte deres modersmål (bortset fra finlandssvenskerne). Ikke blot disse med Träskman i spidsen, men også de finskskrivende som Verkko, Honkasalo og Nuotio har præget NTfK, og fra Island kan efter begyndelsen med Jónatan Thormundsson nævnes Ragnheidur Bragadóttir og Helgi Gunnlaugsson. I ikke få tilfælde har tidsskriftets læsere, som ikke behersker finsk, kunnet læse svenske oversættelser, eventuelt resuméer, af skrifter, der først er kommet på finsk. Endnu fastholdes det, at det svenske sprog er Finlands dør til det øvrige Norden, og islændingene skriver ubesværet på dansk, norsk eller svensk. Jeg ville finde det beklageligt, såfremt det blev almindeligt at skrive på engelsk i et nordisk kriminalistisk tidsskrift.

Hvad har vi vundet og hvad mistet? Boganmeldelserne er en genre, der er blomstret meget op især siden 1949. NTfK's læsere har kunnet følge godt med i både den nordiske og engelsksprogede kriminalistik, og ved at smide tyske bøger i hovedet på mig har redaktørerne holdt en lille dør åben til den tyske kriminalistiske videnskab, som var enerådende til 1933, ja endog til 1945. Derimod må det beklages, at fastlandseuropa bortset fra Tyskland kriminalistisk set er terra incognita. Er der ingen interesse for, hvad der sker i Frankrig og Italien, for blot at nævne de vigtigste lande?

Fra 1952 og fremefter, nu hvert tredje år, bringer et udvidet hæfte næsten alle indledende indlæg til de nordiske kriminalistmøder og giver derved ikke blot mødedeltagerne, men alle tidsskriftets læsere et frisk og levende indtryk af tidens væsentlige spørgsmål, særlig nyttigt når der er mere end én forfatter på et emne, så dette kan belyses fra mindst to lande. Temanumrene i de sidste år er også en god nyskabelse, således om prostitutionen på et tidspunkt, hvor debatten om straf for »sexkøb« - hvilket skrækkeligt ord - var mest indædt. 
Andre selvfølgelige indslag fra de tidligere år er derimod forsvundet. Jeg tror ikke, at mange savner de udførlige, mange sider fyldende statistiske oplysninger om fængselsvæsenet. Lidt mere savner jeg domsreferaterne, som særlig Leivestad dyrkede i 1950'erne, siden mest Lindegaard, der bragte de sidste i 1991. Jeg så også gerne, at vedtagelsen fra 1968 om at optrykke foredraget og debattens hovedpunkter fra årsmødet $\mathrm{i}$ foreningerne var blevet respekteret, da den nordiske Årsbok desværre ophørte, men det er nok omsonst at bede om det; her trøster jeg mig med indlæggene fra kriminalistmøderne, som giver brillante indblik i de mest aktuelle kriminalistiske spørgsmål fra de andre lande. Mest savner jeg kronikken, oprindelig en kort meddelelse hvert år fra hvert land om vigtig lovgivning, opsigtsvækkende sager som den bizarre finske rigsretssag, refereret i 1996, senere - omtrent som når en fortravlet dagbogsskriver gør en kraftanstrengelse og indhenter mange dage på én gang - ved opsamling, Finland v/Träskman i 1993 og Island v/Ragnheidur Bragadóttir i 1994, kulminerende og desværre sluttende med Strandbakkens kolossale reportage i 2003 om forløbet af den norske kodifikation, samme år som den sidste danske kronik v/Elholm. Jeg er klar over, at kronikken ikke anses som videnskabeligt meriterende arbejde, men det burde være muligt at formå en yngre kriminalist, eventuelt redaktionssekretæren, til at skrive den. At bede om opsamling for de mellemliggende år er omsonst, men begynd i det mindste forfra med situationen i dag.

Er der stadig behov for et NTfK, eller kan man nøjes med de nationale tidsskrifter? Som et organ for internordisk orientering og debat kan det ikke undværes og særlig ikke de store hæfter fra kriminalistmøderne. Nok er de nordiske lande gledet lidt fra hinanden, men de er stadig så nær, at udbyttet ved at følge med i, hvad der sker i de øvrige fire lande (og hjemme/selvstyreområder), er intakt. Jeg vil derfor slutte med ikke blot en hjertelig tak og lykønskning til redaktionen for de første fornemme 100 år, men med et lige så dybtfølt ønske om liv og fremgang i de næste 100 år.

\section{Note}

1. Fhv. dommer 